José Paiani Spaniol

\title{
Verticalidade e Espelhamento
}

Tese apresentada ao Programa de Pós-Graduação em Artes Visuais, Área de Concentração Poéticas Visuais, da Escola de Comunicações e Artes da Universidade de São Paulo, como exigência parcial para obtenção do Título de Doutor em Artes, sob a orientação do Prof. Dr. Marco Garaude Giannotti. 
doutorado 4/27/09 9:59 PM Page 2 


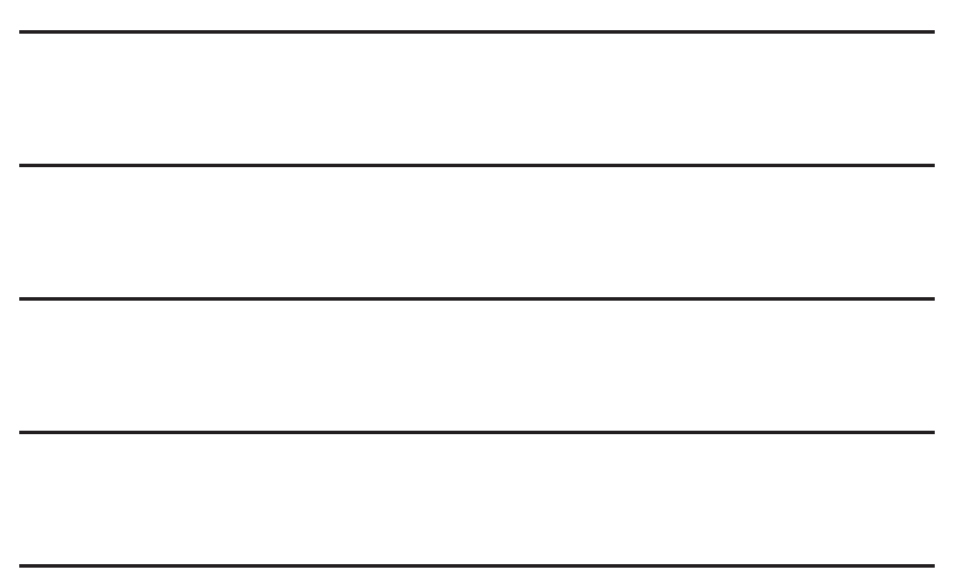


doutorado 4/27/09 9:59 PM Page 4 
Dedico a Clemente Spaniol (in memoriam). 


\section{Resumo}

Neste ensaio trato de minha produção artística dos últimos vinte e cinco anos por meio de dois tópicos: Verticalidade e Espelhamento. Com base nisso, os assuntos abordados foram separados em dois blocos principais: I. Espelho horizontal, em que estão reunidos assuntos como reverberação, equilíbrio e um observador em movimento; e II.Espelho vertical, que está ligado ao tema da ascensão, da queda e sua relação com um único ponto de vista. Assim, é possível se chegar a uma visão de conjunto de toda minha obra, da qual selecionaram-se os trabalhos que demonstram melhor as relações aqui apresentadas.

Ao final, apresento uma nova obra, Tímpano, que será realizada e exposta na Capela do Morumbi, um dos espaços pertencentes ao Museu da Cidade em São Paulo. A construção da peça ocorrerá durante o mês de maio e a inauguração no princípio de junho.

Palavras-chave: Arte Contemporânea Brasileira; Escultura; Instalação; Gravura; Fotografia. 


\section{Abstract}

In this essay I would like to make a dissertation of my artistic work of the last twenty five years through two topics; Verticality and Mirroring. Based on this, the subjects that are approached were divided into two main topics: 1: Horizontal mirror, where subjects such as reverberation, equilibrium and an observer in movement are reunited. 2.Vertical mirror, that is linked to the theme of acension and fall and its relation with one only point of view. In this manner one can have a vision of the ensemble of my work, out of which were selected the works which better demonstrate the relations presented here.

Finally, I present a new discourse:"Timpano" which will be set up and exhibited in the Capela do Morumbi in one of the spaces that belong to the Museu da Cidade in São Paulo."Timpano" will be executed during the month of May and the inauguration will take place in the beginning of June.

Keywords: Brazilian Contemporary Art; Sculpture; Installation; Engraving; Photography. 


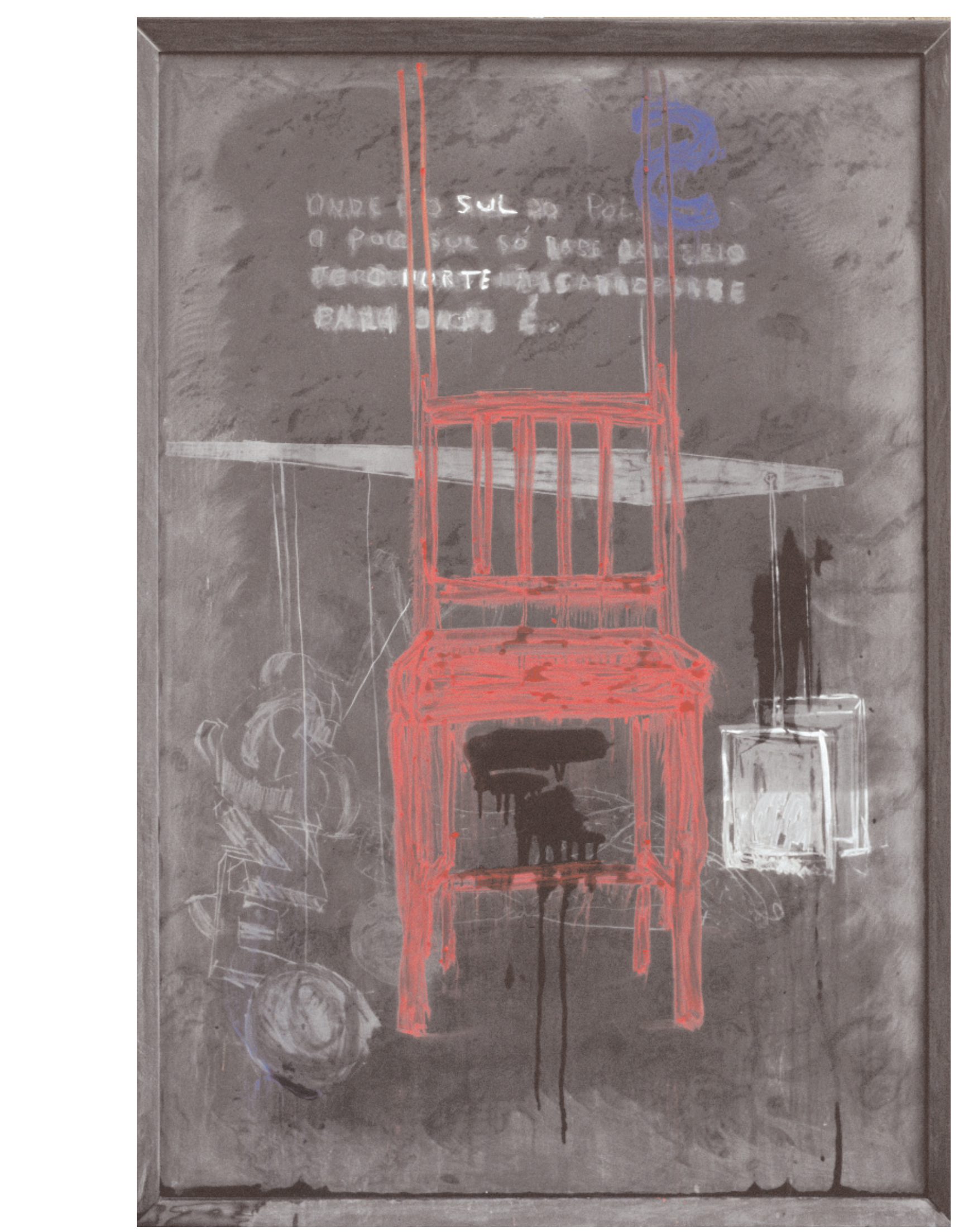

Lousas, 2009, pastel sobre pedra, $98 \times 135 \mathrm{~cm}$.

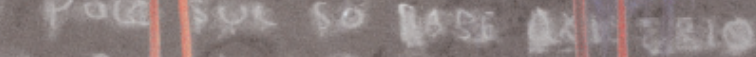

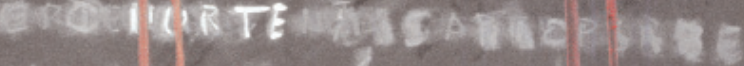
artal alowe Gor 


\section{Sumário}

12 Agradecimentos

13 Nota introdutória

15 Introdução

18 Trabalhos Selecionados

24 Vitória Régia e Comidas

30 Mirante

34 Biblioteca e Balanças

38 Teto Chão

42 Colunas

48 A Casa e o Bosque

50 O Descanso da Sala

54 Balanças e Lousas

58 Tímpano

63 Bibliografia 


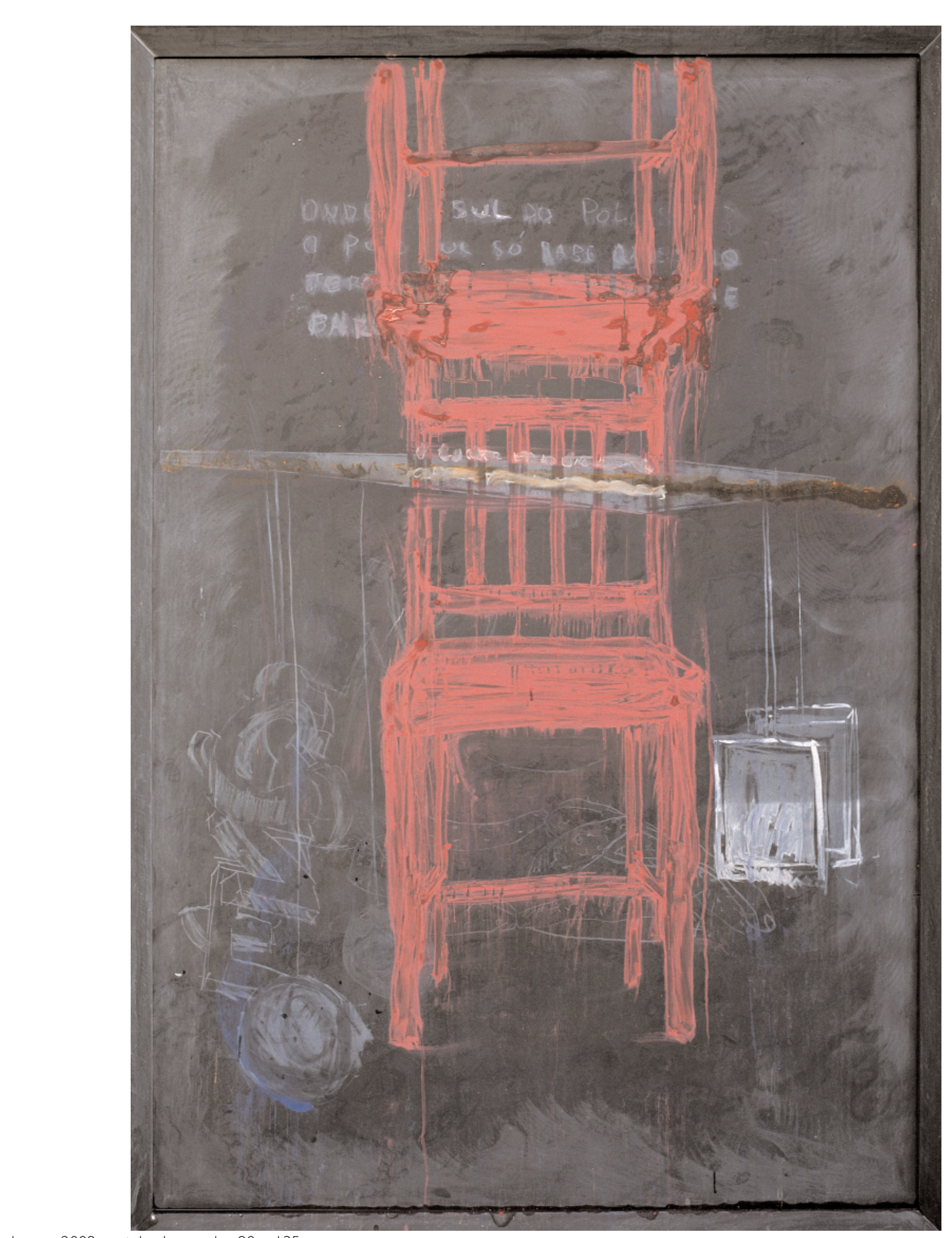

Lousas, 2009, pastel sobre pedra, $98 \times 135 \mathrm{~cm}$. 


\section{Verticalidade e Espelhamento}




\section{Agradecimentos}

Este trabalho foi realizado com a colaboração e generosidade de muitas pessoas. Sou grato a Marco Giannotti, meu orientador, pela amizade e ajuda em diversos momentos. A Agnaldo Farias e Luciano Migliaccio pela atenção e sugestões durante a qualificação. A Evandro Carlos Jardim pelos seus ensinamentos. A Inês Raphaelian por acreditar no meu trabalho. A Marcia Pastore por sua generosidade e empenho. A Valmir de Sousa por me ajudar em várias descobertas. A Mario Ramiro por me transmitir seu entusiasmo. Por diversas razões aos amigos Theo Werneck, Hermam Tacasei, Marcos Ribeiro, Fernanda Rossi e Fábio Cardoso. Aos meus marchands Heloisa Amaral Peixoto, Marco Mello, Jorge Viegas. Ao carinho da minha família, a minha mãe Alda Paiani Spaniol pelo seu amor, a meu filho Rodrigo por sua alegria, e a minha mulher Helena Martins Costa por estar sempre junto de mim. 
Esta tese organiza-se como um ensaio fragmentado. Fragmentado porque não reúne os assuntos de acordo com um plano comum. Fundamenta-se mais em interesses isolados do que numa concepção geral abrangente, buscando alcançar uma síntese. Essa reunião de idéias surge de uma ordem partida, semelhante às colagens, em que a razão comum entre as partes termina por estabelecer um todo irregular. $O$ texto emerge da prática artística e, como tal, preserva o seu caráter especulativo. Por essa razão, não almejo chegar a definições nem ser conclusivo; pelo contrário, vagueio em torno de alguns "achados", através dos quais procuro criar um encadeamento por meio de minha linguagem artística. 


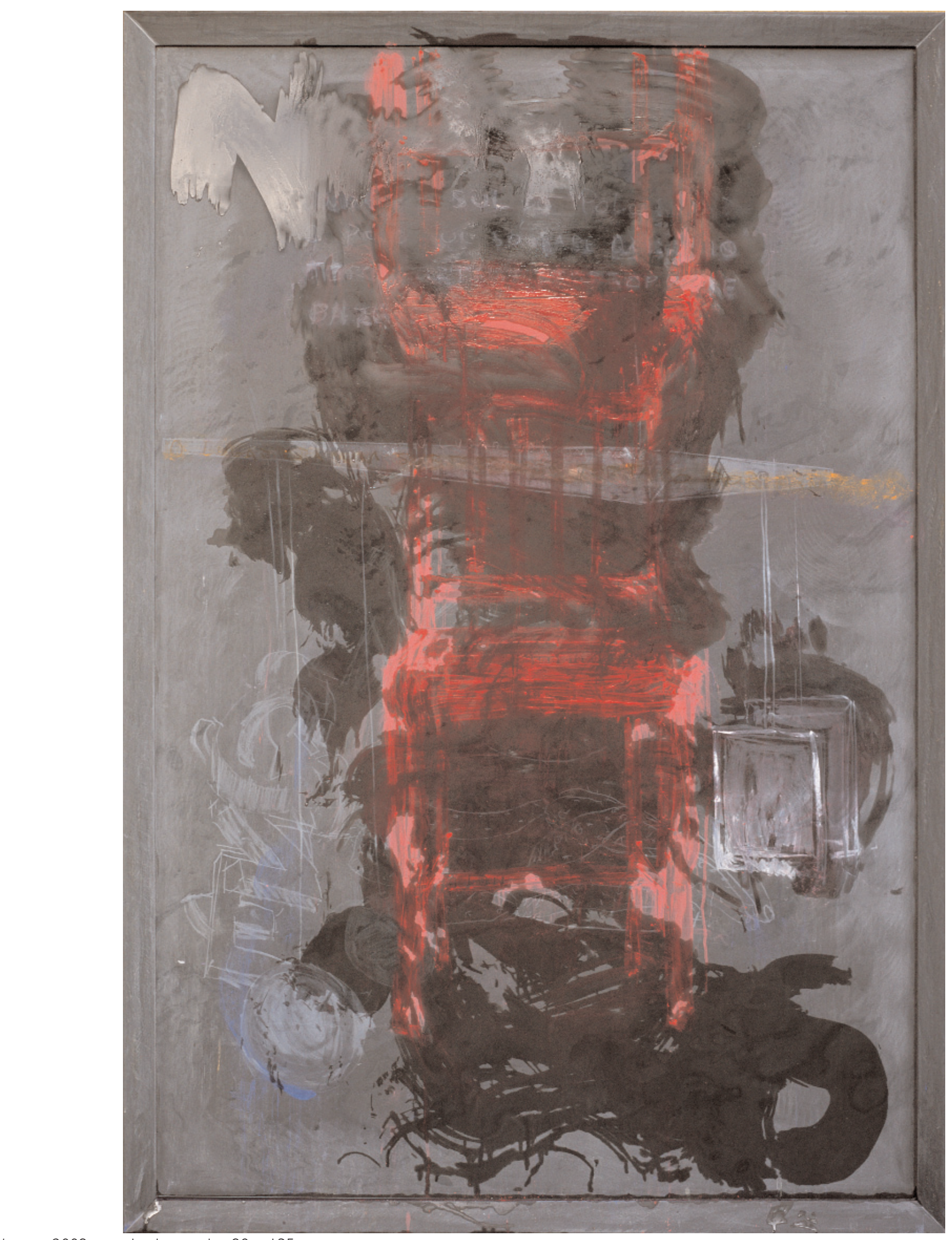

Lousas, 2009, pastel sobre pedra, $98 \times 135 \mathrm{~cm}$. 


\section{Introdução}

Dois tópicos norteiam este texto: verticalidade e espelhamento. Através deles, acredito ser possível se ter uma visão de minha produção artística dos últimos vinte e cinco anos. Em alguns momentos estes aspectos são flagrantes em minhas obras, ligados diretamente ao foco central da forma; em outros, permanecem latentes, subordinados à estrutura fundamental do trabalho, ocultos sob a composição.

Inicialmente olho para os objetos, para suas proporções, para os ângulos e soluções construtivas. Em seguida, penso em sua distribuição pelas salas, para o lugar que lhes é reservado dentro dos ambientes, na lógica adotada na ocupação dos espaços. A estas considerações, acrescento uma afinidade que tenho pela maneira como são arrumados os interiores das casas no Brasil. Nas pequenas cidades, por exemplo, é freqüente o gosto de contrapor uma diagonal a ângulos retos. Sempre delicadas e singelas, essas manifestações geralmente ocultam-se sob pequenas ações decorativas. Talvez seja esta a verdadeira ordem presente em nossa bandeira nacional. Uma das variações mais comuns desse hábito brasileiro é uma pequena toalha em diagonal atravessando os ângulos de uma mesa. E sobre a toalha, contrariando novamente os ângulos retos, há uma bandeja. Outra variação é trancar os cantos das paredes, disposição que funciona como uma espécie de amuleto para impedir que o indesejável ali se instale. Como se fosse uma passagem para outra dimensão, os cantos parecem sugerir um mau agouro, por isso devem estar sempre fechados, impedindo que algo entre por ali. Estão sempre atravancados, seja por um armário, um aparador ou uma pequena mesa ornada com toalhas e bibelôs. O importante é obstruir a passagem.

Afinado, então, a essas manifestações, procuro rearticulá-las, observando de que modo podem impulsionar novos trabalhos. Anterior à percepção dos objetos e aos princípios construtivos, um aspecto dá início a esta mediação. Minha visão surge de um apreço pela funcionalidade das coisas e por essa ambientação dos objetos no cotidiano. Tento neutralizar esse sentido prático, mas ao mesmo tempo preservar o que lhes é habitual, a memória dessas situações comuns. Por este motivo me interesso por objetos, situações ou ações que já estejam em desuso, quando o seu sentido prático já esteja fragilizado ou não seja mais objetivo. A imagem surge dessa metamorfose, desprende o objeto de seu mundo genérico sem anular completamente sua antiga função. Perdura em graus diferentes uma certa utilidade nos objetos, que advém do confronto entre proficuidade e sua negação. Apesar de conservarem aparentemente um vínculo com sua antiga serventia já não convêm para nada a não ser para a contemplação. Tornaram-se para mim uma estratégia poética. Através deles a minha prática se faz e minha 
experiência se concretiza; oferecem-me uma possibilidade de percepção, de interlocução, de compreensão dos fenômenos a minha volta. Como se pudessem refletir o mundo em sua superficie.

No meu trabalho noto que além da referência aos objetos cotidianos, existe um outro conteúdo que participa de modo decisivo na criação das peças. As imagens emergem de um determinado ponto de vista e a ele estão ligadas. Sugerem ao observador um modo de olhar para a obra, questionando sua visão preconcebida dos objetos. Como uma forma de compensação ao vazio deixado pela falta de função, o olhar do observador complementa a imagem, sua presença confere um sentido à obra. A relação é de estranhamento, o trabalho não reafirma a ordem do mundo ou a ela se agrega; provoca, em vez disso, mais desestabilização do que quietude.

A prática artística suscita processos retroativos, como se numa inversão, o passado pudesse ser conseqüência do presente. Um novo trabalho representa uma chance de ressignificação dos anteriores. Quando um conteúdo é identificado, quer dizer que ele já estava presente havia muito tempo, em geral integrando uma cadeia de acontecimentos. A partir desta perspectiva é possível ampliar a compreensão dos trabalhos anteriores, através de novos entendimentos. Quando o espelhamento tornou-se um conteúdo evidente na minha poética, pude verificar que vários trabalhos já continham este assunto. $\mathrm{O}$ espelho que meu trabalho contém é plano e opera orientado através de eixos horizontais e verticais - e em cada caso os resultados são completamente diferentes.

Separei então os tópicos verticalidade e espelhamento em dois blocos principais, possibilitando dessa maneira abordar outros assuntos correlatos. Chamei o primeiro de "Espelho horizontal", no qual estão reunidos conteúdos como "reverberação", "equilíbrio" e "um observador em movimento". No segundo bloco, "Espelho vertical", estão ligados ao tema da ascensão, da queda e sua relação com um único ponto de vista

Os "Espelhos horizontais" estão sempre num eixo frontal ao nosso, à altura de nossos olhos. Nesse plano, nos situam no espaço por uma lei de continuidade. Torna-se um instrumento de extensão da nossa visão, potencializam o alcance de nosso olhar, multiplicando o nosso ponto de vista. O reflexo cria para os olhos algo semelhante ao que a reverberação cria para os ouvidos. Somos duplicados, cada um de nós se vê como se fôssemos um outro, como os outros nos vêem. Desse confronto amplo surge o entendimento sobre nós mesmos. Por meio dele cria-se a possibilidade de reconhecimento de nossa própria imagem: identificamos e relacionamos o que vemos como nossa identidade. Este eixo nos coloca em movimento,

El Greco, O Funeral do Conde de Orgaz. 1588, óleo sobre tela, $460 \times 360 \mathrm{~cm}$. permite que caminhemos no espaço, através dele é possível procurar, 
localizar, verificar. O reflexo neste caso estabelece uma relação de equilíbrio, entendido como uma medida de proporção: o que se vê no espelho corresponde a nós e ao que está ao nosso redor.

Por outro lado, quando estão dispostos no chão, abaixo da linha de nossos olhos, os espelhos nos impõe a verticalidade. Neste eixo, estão as pinturas ascensionais, de cúpulas de igrejas e dos tetos dos palácios. Elas nos colocam diante do improvável, do que é desestabilizador. A imagem com a qual nos deparamos não faz parte do cotidiano. Guiado por esse ponto de vista intangível, não se verifica coisa alguma, não se estabelecem provas. Não nos vemos nem nos localizamos nesse plano incomensurável; pois, como a continuidade do espaço é relativa, não é possível precisar onde se está. Acontece algo semelhante nas composições orientais, especialmente nas gravuras de Hiroshige. Com freqüência nossa perspectiva é aérea, não se define por aspectos fixos, diante deles também flutuamos. Espelhos verticais são vertiginosos, enfraquecem as medidas, dissolvem os limites. Promovem uma instabilidade delicada, quase um desconforto.

Diante de um espelho no eixo frontal, esperamos por identificação, por reconhecimento, por uma reafirmação do nosso mundo palpável. Mas quando o espelho está no eixo vertical, quando está em um nível abaixo de nossos olhos, deparamo-nos com a instabilidade, com limites fragilizados pela falta de referências claras.

Sendo assim, selecionei alguns trabalhos nos quais esses tópicos estão presentes, aparecendo em cada caso transformados pela composição: Vitória Régia (1994) e Comidas (2002), Mirante (1997), Biblioteca e Balanças (1999), Teto Chão (2002), Colunas (2003), A Casa e o Bosque (2005), O Descanso da Sala (2006) e Balanças e Lousas (2008/2009).

Por fim gostaria de incluir um capítulo dedicado a um novo trabalho, chamado Tímpano. Trata-se de uma instalação que será exposta, a partir do mês de maio, na Capela do Morumbi, uma das unidades do Museu da Cidade. Para a construção dessa peça, será utilizada uma adaptação moderna do processo de taipa de pilão, mesma técnica construtiva usada para erguer a capela em 1825. E para que se possa ter uma idéia mais aproximada da natureza deste trabalho, serão incorporadas a esta tese algumas vistas da maquete virtual da obra.

De todo modo, existe uma diferença muito grande entre escrever sobre um trabalho já realizado e sobre outro ainda por ser feito. Sobretudo porque as questões fundamentais vão se revelando durante a construção; por isso, apesar das considerações incluídas no texto a respeito dessa instalação, somente após o termino da obra poderei compreender melhor o alcance do trabalho.

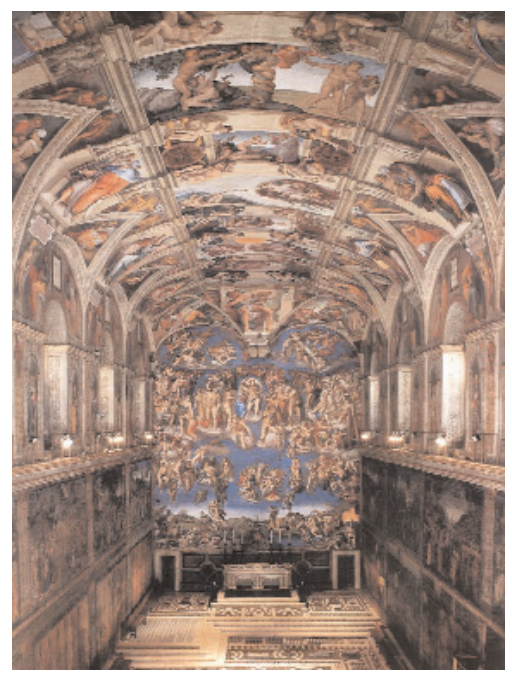

Michelangelo, Capela Sistina, 1508 / I510, afresco.

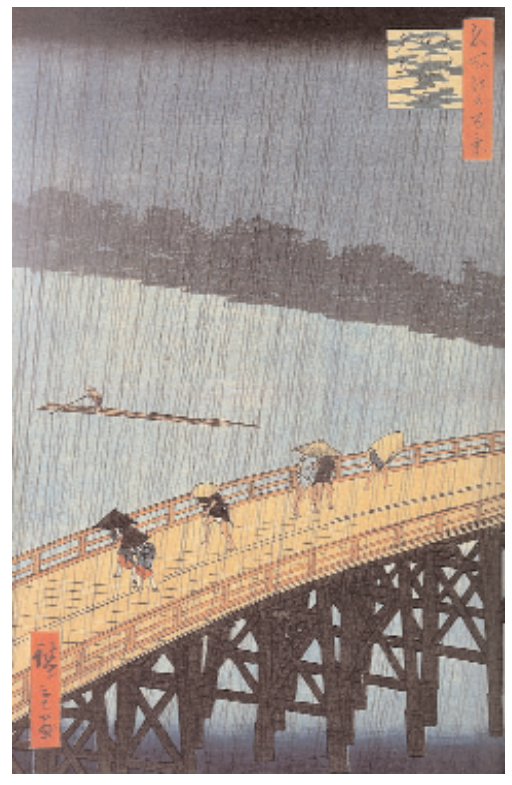

Hiroshige, Evening Shower at Atake and the Great Bridge, I 856 / 1858, xilogravura a base d'água, $37,5 \times 25,5 \mathrm{~cm}$. 




Escada, 1985, gravura em metal, $60 \times 30 \mathrm{~cm}$.

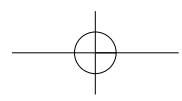




\section{Trabalhos Selecionados}

Entre 1990 e 1993 vivi na Alemanha, em Colônia, como bolsista do Serviço Alemão de Intercâmbio Acadêmico (Deutscher Akademischer Austauschdienst, DAAD). Nesse período, matriculado na Academia de Artes de Düsseldorf, adotei, logo nos primeiros meses, a escultura como meio expressivo principal de minha produção. Também pela primeira vez passei a incluir textos como conteúdo poético em meus trabalhos. Provavelmente conseqüência da enorme mobilização necessária para aprender uma língua estrangeira em poucos meses. A fluência torna o idioma um veículo; sem ela, porém, articulamos os pensamentos palavra por palavra, como se as letras fossem pedaços materiais de uma estrutura.

A aproximação com o meio tridimensional se deu pelo texto e pela palavra. No início, utilizei carimbos e, posteriormente, a fundição de letras em parafina. Com isso descobri uma espécie de ordem quantitativa da língua. Por exemplo, para a frase "Onde é o sul do pólo sul?", precisei fundir dezoito letras e um ponto de interrogação; somente da letra "o" foram necessárias cinco cópias.

Ao rever os últimos trabalhos realizados no Brasil antes dessa viagem, percebo que já havia uma indicação desse acercamento com os meios tridimensionais. Contudo, até este momento, mesmo tendo abandonado a pintura sobre tela, o assunto principal de meu trabalho ainda estava ligado às questões da cor e ao plano bidimensional. Nessa época estava em busca de um suporte com qualidades plásticas mais pronunciadas, que participasse de maneira mais efetiva dos conteúdos da composição e que não fosse tão passivo.
Sem título, 1985, afresco, $160 \times 250 \mathrm{~cm}$. Frente e verso.

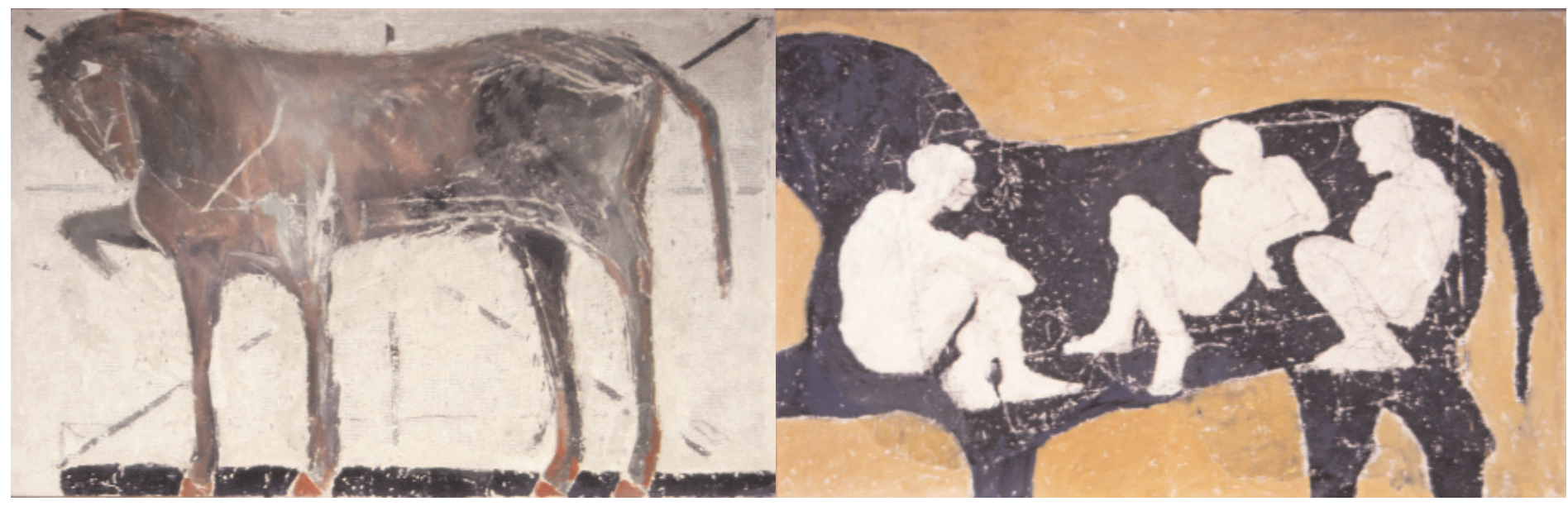


Esta aproximação com a escultura já vinha acontecendo desde 1985, ocasião em que realizei experimentações utilizando a técnica tradicional de afrescos. Experimentações que me permitiam continuar trabalhando com a cor, mas sobre uma superfície pictórica de argamassa, com relevos e volumes variados. Construí paredes móveis para receber a pintura afresco, estruturas de madeira e metal soltas no espaço, que sustentavam a argamassa. Desse modo foi possível pintar dos dois lados das paredes. Olhava-se para os trabalhos caminhando em torno deles, como se faz normalmente com a escultura. O assunto das pinturas eram cavalos e figuras humanas. De um lado, somente um cavalo, quase em tamanho natural, representado por uma pintura ligeira, de pinceladas largas e grandes planos de cores transparentes. A figura tinha muita dinâmica e movimento, uma ação gerada pelas sobreposições de cores. Do outro lado, víamos a silhueta de homens dentro de um outro cavalo. Uma representação mais gráfica e constituída por planos chapados opacos, uma tinta mais espessa, sem se valer tanto do meio líquido para obter a fatura. A superficie irregular deixava ver muitas vezes a as telas de metal sob a estrutura de argamassa. Foram exibidos numa exposição coletiva chamada "Seis Agosto", realizada no Museu de Arte Contemporânea da USP, no Parque Ibirapuera em São Paulo. Eram muito frágeis, após o transporte até o museu, foi preciso refazer a argamassa e repintar boa parte dos trabalhos. Curiosamente, após as rachaduras e fragmentos perdidos, o trabalho ficou realmente pronto. Não era possível confundi-lo com peças arqueológicas, a fatura não permitia o entendimento do um objeto como subterfúgio ou algo "falso". Parecia deslocado do tempo, novo mas já uma ruína, um fragmento que não permitia localizar sua origem.

Também desse período anterior à viagem à Alemanha é a série Sarrafos, em cujos trabalhos o interesse pela pintura permanece. As composições surgem sobre estruturas de madeira ${ }^{1}$. Mas nessa série a pintura não é mais figurativa, Mira Schendel, Sarrafo, 1987, têmpera acrílica e gesso sobre madeira, $96 \times 180 \times 47,5 \mathrm{~cm}$.

1 Os Sarrafos de Mira se projetam para fora do plano, são tridimensionais. os sarrafos foram pintados com cal, conseqüência direta da experiência com os afrescos. A figuração foi substituída por um sentido presente nos próprios materiais. Pintar com cal parece evocar por si só alguns significados: purificação, proteção, memória e esquecimento, esterilização e limpeza; parece revelar a capacidade metafórica da matéria e suas substâncias.

Foram apresentados na galeria Paulo Figueiredo, meses antes da minha partida. Nessa ocasião, durante a abertura da mostra, fui apresentado a Amílcar de Castro. Disse-lhe que para mim aqueles trabalhos eram pinturas. Ele respondeu com um comentário acerca do aspecto musical da composição, enfatizando a presença de uma certa sonoridade advinda do ritmo entre os sarrafos. Por fim, discordando de mim, argumentou que aquelas peças eram quase uma escultura, e que se assim eu continuasse, em breve meu assunto passaria para o volume. Isso se cumpriu nos anos em que estive na Alemanha e continuou na volta ao Brasil. 

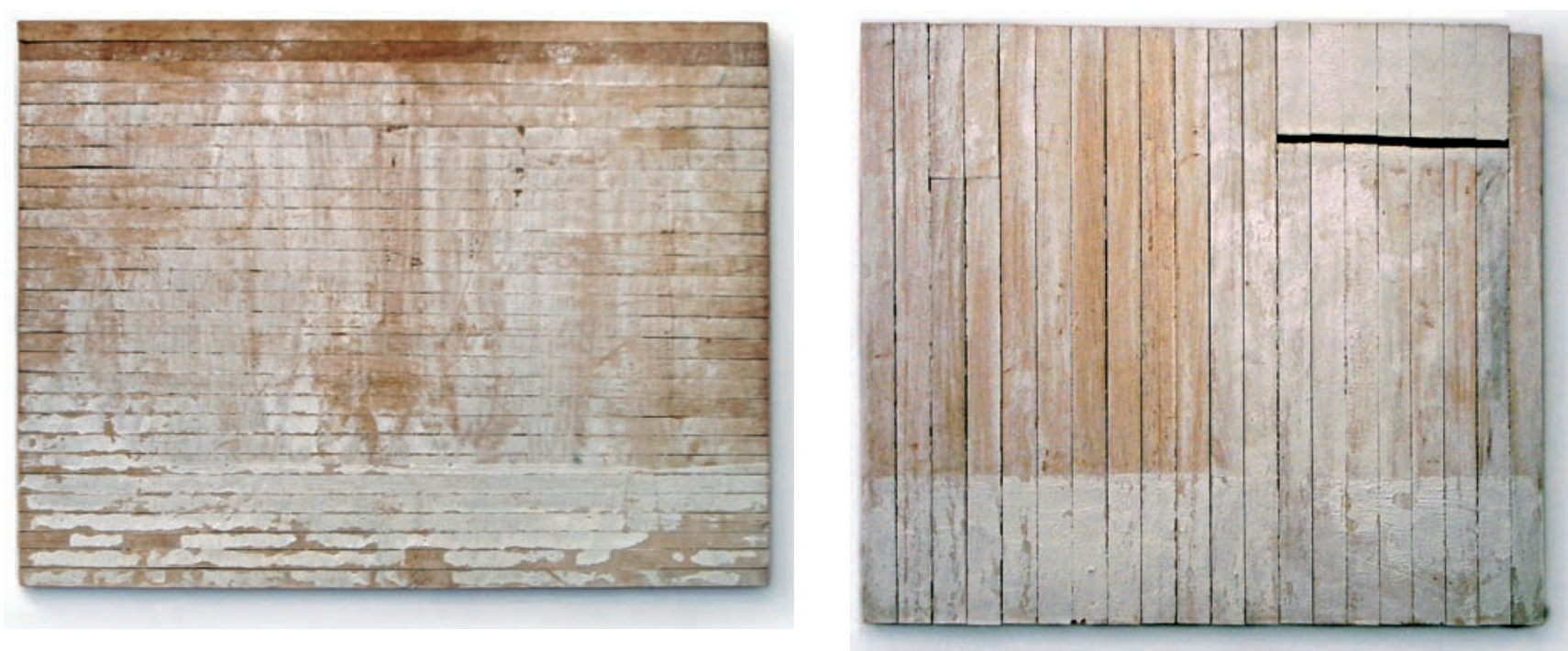

Sarrafos, 1986/90, cal sobre madeira, $4 \mathrm{I} \times 5 \mathrm{I} \mathrm{cm}$ e $50 \times 42 \mathrm{~cm}$.

Livro, 1990, xilogravura à base d'água, $45 \times 55 \mathrm{~cm}$.
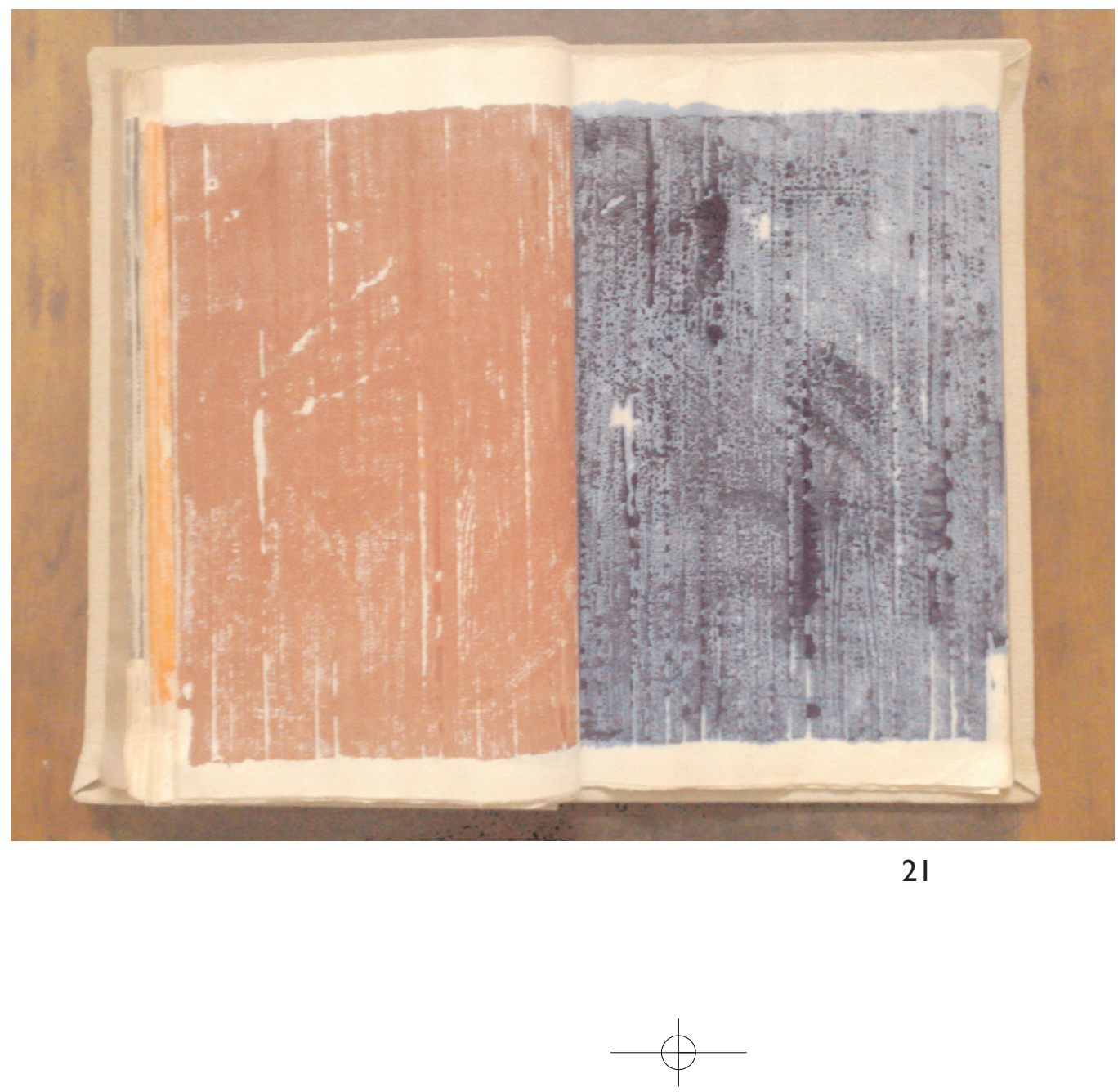

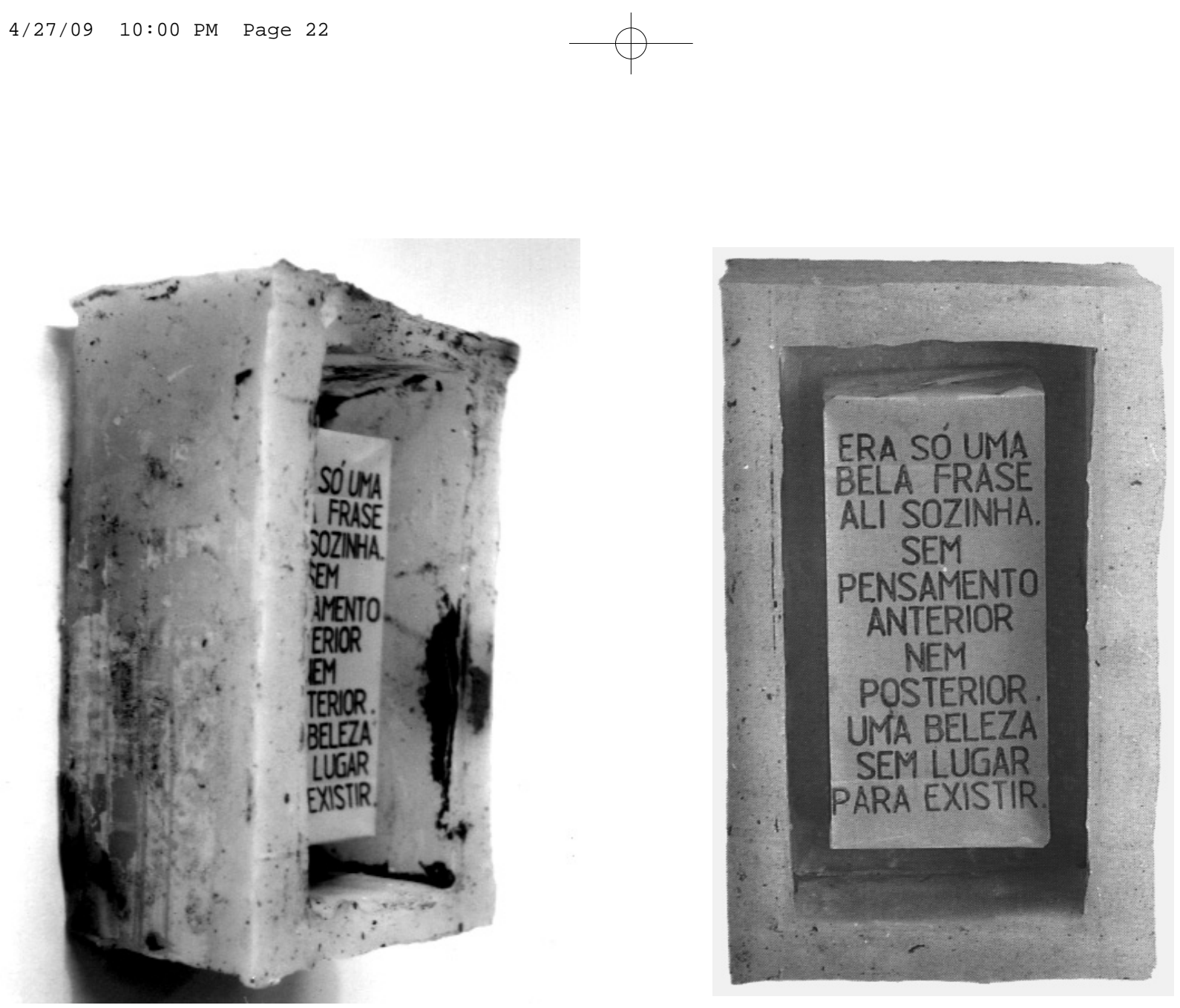

Era só uma bela frase, 1993, parafina, papel, $30 \times 12 \times 9 \mathrm{~cm}$.
Nos primeiros meses dessa temporada na Alemanha realizei trabalhos com parafina e papel. Eram prismas feitos a partir de formas geométricas muito simples, construídas com dobradura de papel, nas quais estamparam-se frases curtas. Buscando uma unidade entre os papéis dobrados e a parafina fundida, decidi utilizar papel manteiga ou vegetal, criando uma ambientação entre os elementos. Por este motivo os volumes eram transparentes induzindo que olhássemos os textos também pelo lado trás, invertidos como em um espelho. Estes prismas eram acomodados dentro de caixas de parafina, fundidas diretamente em moldes de argila molhada, deixando resíduos em sua superfície. Após a retirada da peça perdia-se o molde, sendo necessário reconstruí-lo integralmente a cada processo de fundição. O contraste entre os blocos compactos e sólidos de parafina fazia com que os prismas de papel parecessem extremamente frágeis, tornando mais singelo ainda o sentido das frases.

A pequena escala dos trabalhos criava uma relação semelhante à que temos diante de oratórios, só que em vez de santos havia frases. Desde essa época, os textos já ganhavam corpo através da transparência dos prismas. Abandonavam o espaço virtual para adquirir volume. Contudo, ainda olhávamos para os objetos como quem lê a página de um livro, ainda um gesto solitário e intimista. Quem lê um livro, mesmo que rodeado por outros, volta-se sobre si mesmo. 
A condição do vôo não é a física, nem o

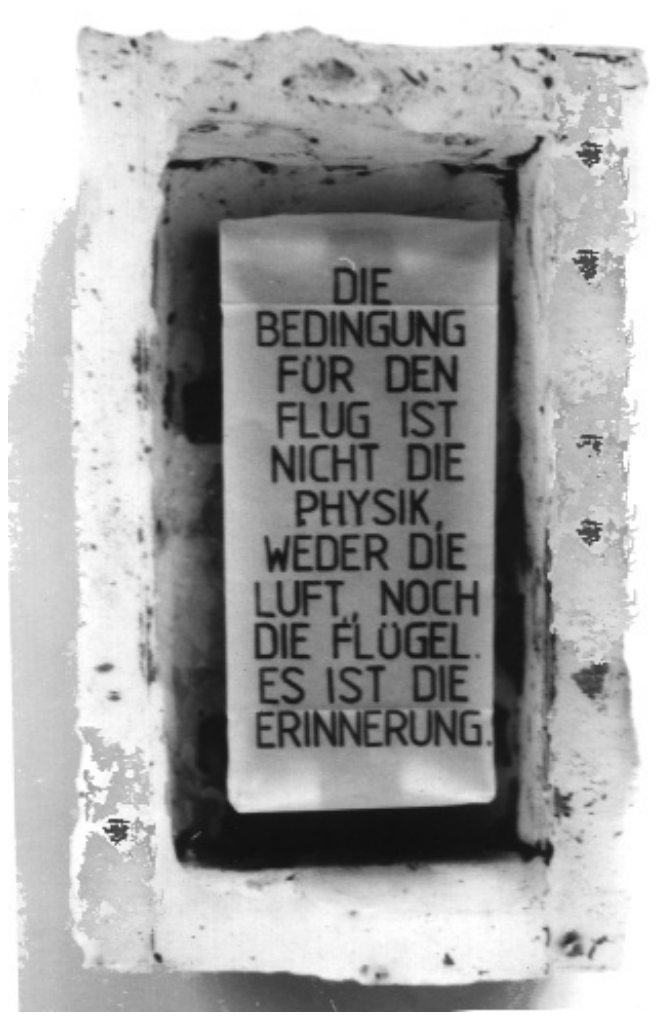

ar, nem as asas. É a memória., 1992,

parafina, papel, $30 \times 12 \times 9 \mathrm{~cm}$.

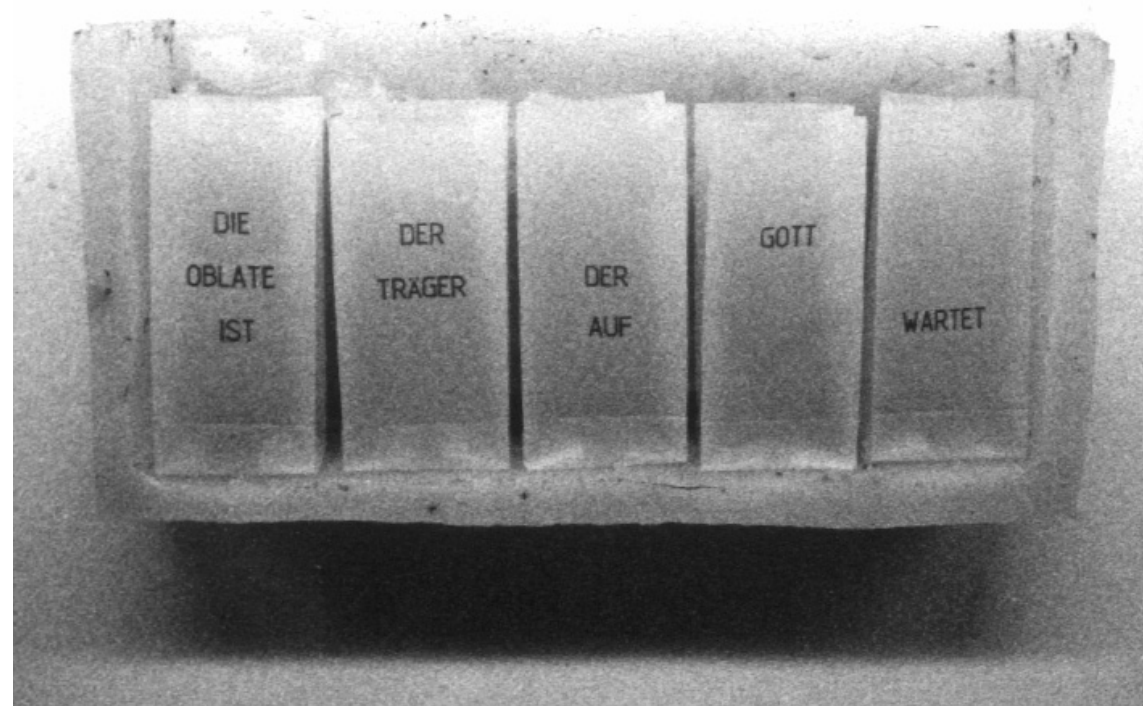

A Hóstia é o suporte à espera de Deus. 1992, parafina, papel, $25 \times 55 \times 9 \mathrm{~cm}$. 


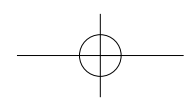

2 Os trabalhos Vitória Régia e Comidas surgem desse contexto. Eles foram apresentados em São Paulo, em 1994, na galeria São Paulo, e em 200 I, na exposição Palavra Figura, Paço das Artes, com curadoria de Nancy Betis (infelizmente não tenho nenhuma fotografia desta instalação); em Vila Velha, em 2003, na exposição Sal da Terra, Museu Vale do Rio Doce, curadoria Paulo Reis; e pela última vez na cidade da Coruña, na Espanha, em 2006, na exposição Entre a palavra e a Imagem, na Fundação Luis Seoane, curadoria Paulo Reis, Fátima Lambert, Cecilia Pereira.

3 Ao contrário do trabalho de Mira Schendel, onde a letra e a palavra permanecem no plano, expressas através de seu aspecto gráfico.

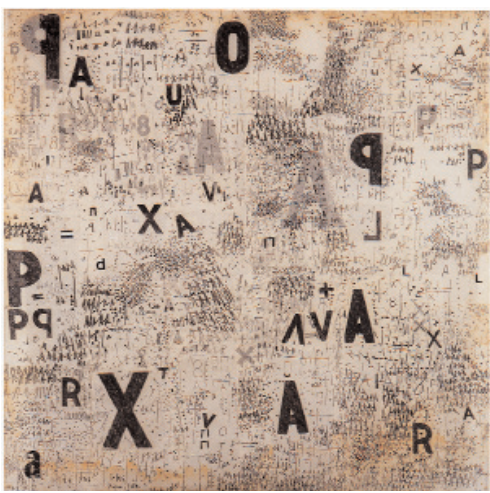

Mira Schendel, 1967, grafite e letraset sobre folhas de papel arroz montadas entre placas de acrílico transparente, $100 \times 100 \mathrm{~cm}$.

Vitória Régia, 1994, argila e parafina, $300 \times 450 \times 400$ cm, Galeria São Paulo. Detalhe.

\section{Vitória Régia e Comidas}

Em 1993, já de volta ao Brasil ${ }^{2}$, continuando o que havia iniciado em Colônia, a estampa permaneceu como um dos procedimentos centrais de minha produção. Nesse período realizei várias experimentações, buscando reformular no meu trabalho as relações entre texto e escultura. A principal mudança talvez tenha ocorrido em relação ao suporte. Anteriormente, mesmo adotando formas tridimensionais como suporte, a escrita permanecia restrita à esfera de seus caracteres superficiais. Nos trabalhos seguintes a palavra ganhou um corpo. Se a escrita normalmente ocupa um espaço virtual, no meu caso a letra parece ter uma vocação de volume ${ }^{3}$. Placas, tabuletas, os mais diversos avisos caminham em direção à matéria. Valem-se do relevo para ocuparem um lugar no mundo das coisas. Nessas obras, o baixo relevo e a fundição, processos característicos da escultura, tornaram possível abordar o texto sem abandonar o meio tridimensional.
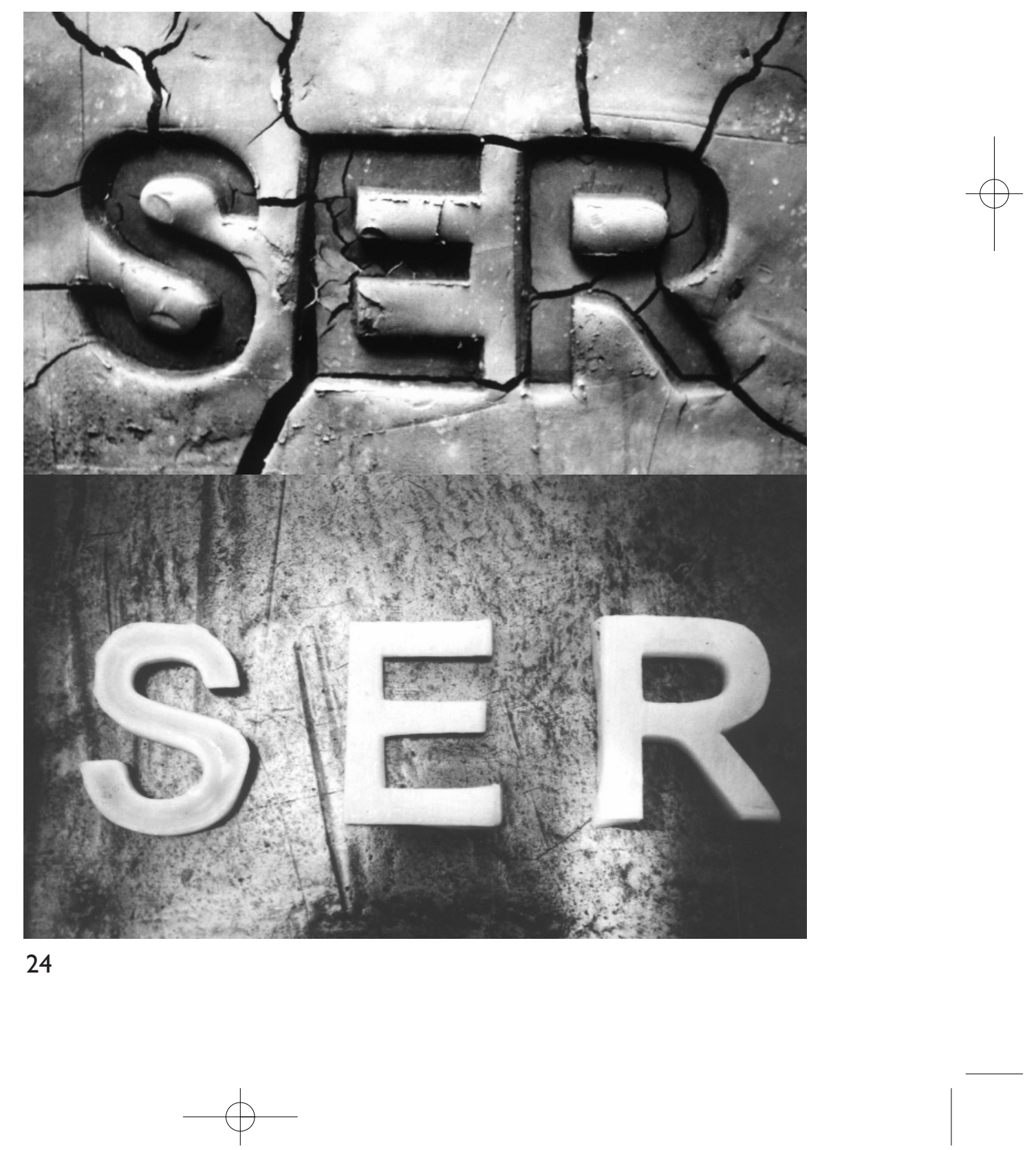


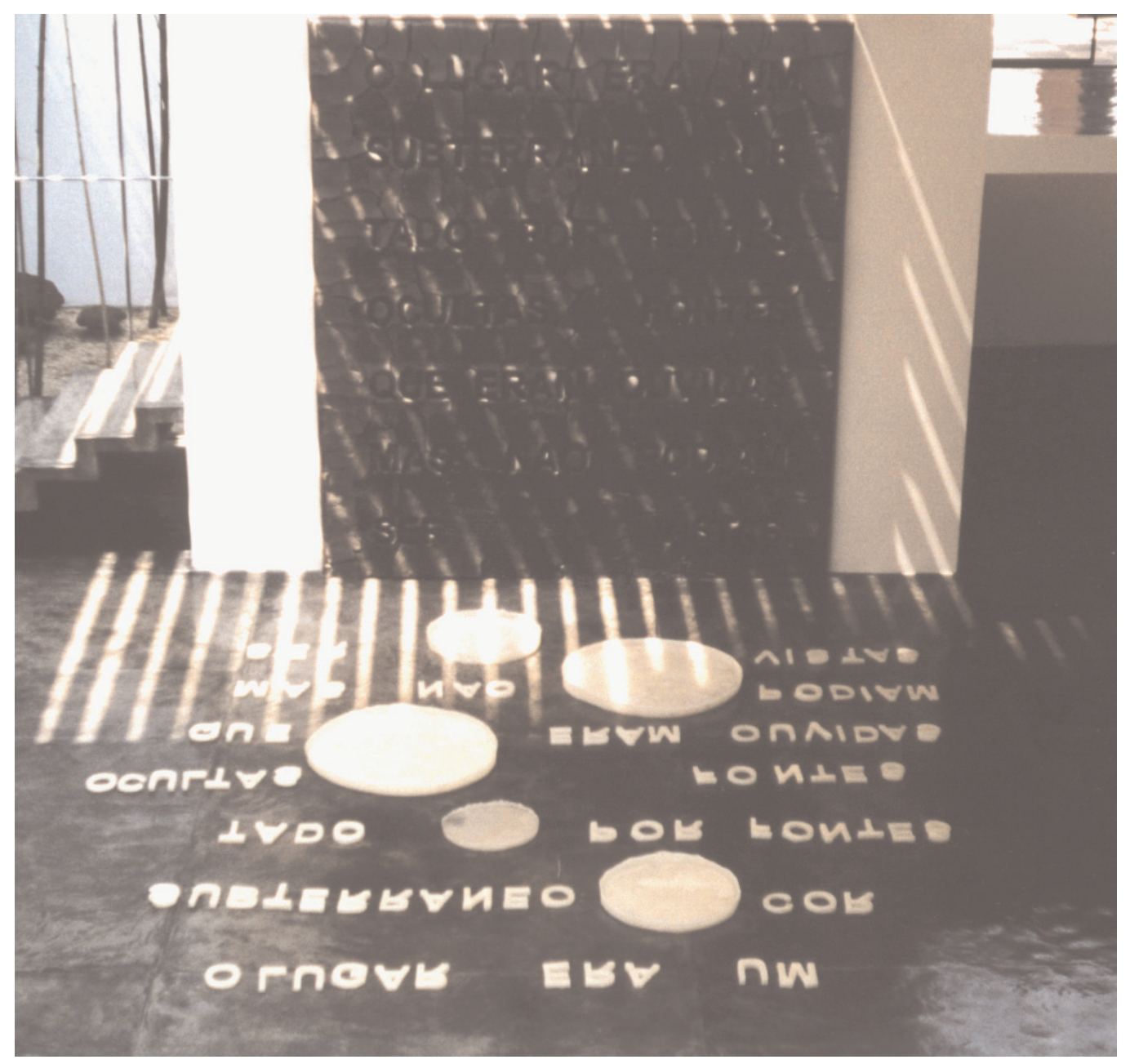

Esses trabalhos são conseqüência direta das peças realizadas na Alemanha, mas com uma grande transformação. No Brasil pude ampliar a escala, até tornar o texto estampado realmente tridimensional. $\mathrm{O}$ resultado expandiu a ação para o espaço, mudando completamente o sentido do olhar. Se antes a referência era o oratório ou o livro, o trabalho agora deixa de ser página para ser lida e passa a ser um objeto relacionando-se com a sala. Se a leitura do livro normalmente remete a um gesto individual e de intimidade, olhar para uma grande parede refere-se a um ato contemplativo e de grupo. Um caminho oposto ao traçado por Giulio Carlo Argan, em seu texto sobre a gravura $^{4}$, a respeito do esforço dos gravadores para traduzir a pintura mural em termos gráficos, adequando a cor à trama da gravura e o caráter monumental à página do livro.
Vitória Régia, 1994, argila e parafina,

$300 \times 450 \times 400$ cm, Galeria São Paulo.

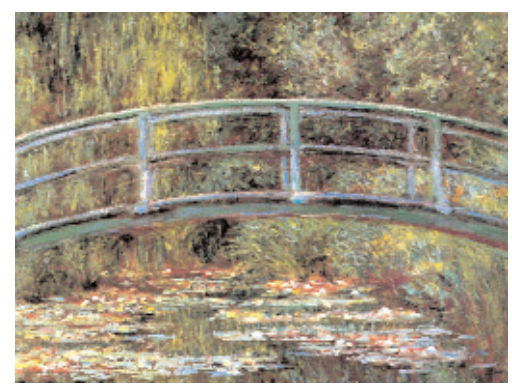

Claude Monet, Waterlilies, 1899, óleo sobre tela, $140 \times 200 \mathrm{~cm}$.

4 ARGAN, Giulio Carlo. "O Valor Crítico da Gravura de Tradução", em Imagem e Persuasão. Companhia das Letras, São Paulo, 2004. 
Em Vitória Régia e Comidas, o baixo-relevo de argila serve de berço para que as letras de parafina ganhassem corpo, reunindo-se numa espécie de união entre forma e matéria. Realizados por um mesmo procedimento, o texto era estampado sobre argila e em seguida as letras eram fundidas em parafina. Em cada edição, as proporções foram adaptadas de acordo com os lugares onde eram apresentados. Nestes trabalhos percebe-se a presença da gravura, um dos principais meios expressivos com o qual trabalhei durante o período de formação ao longo dos anos 1980. A gravura impõe uma ordem; determina, com base em certos procedimentos internos, um modo específico de articular conteúdos. Mediante um sentido gráfico presente na estrutura de muitos trabalhos, foi possível transportar esses procedimentos para outros meios expressivos correlatos. Para o jogo entre matriz e cópia, por exemplo; o alto e baixo relevo; a imagem elaborada em etapas depois se inverte através da impressão. Na gravura, a impressão reflete a matriz, mas curiosamente é na cópia que a imagem se realiza plenamente, como se o reflexo no espelho pudesse ser mais vivaz que o referente. Havia sempre uma alternância de sentidos entre a estampa sobre argila e as letras fundidas em parafina. Ora

Pêndulos, 2009, litografia, 60 × $40 \mathrm{~cm}$.

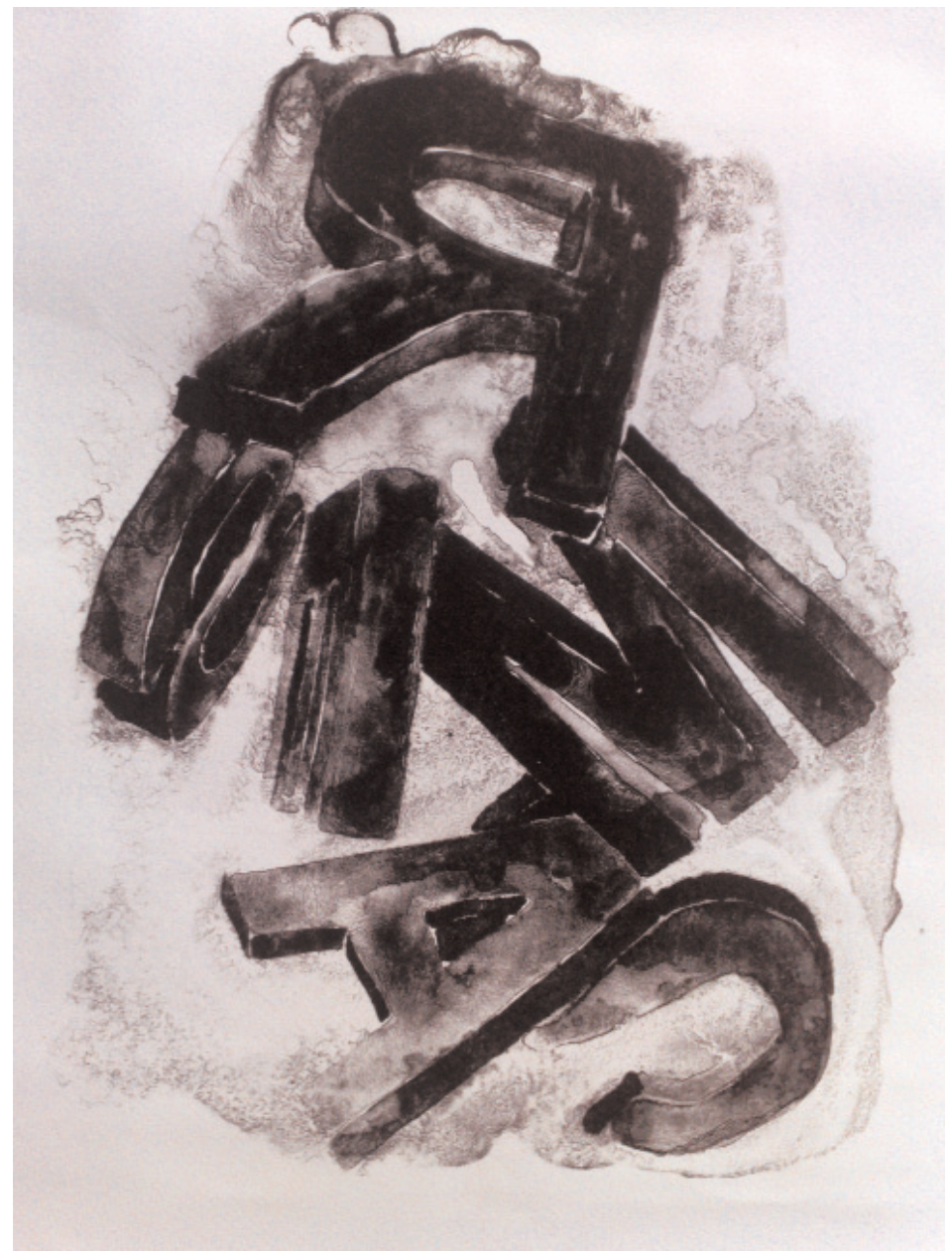


líamos o texto estampado em baixo relevo na parede de argila, e as letras de parafina estavam ali como reflexo, ora era a parede que tornava-se sombra das letras em relevo no chão.

Em Vitória Régia, uma frase foi estampada em baixo relevo sobre uma parede de argila: "O lugar era um subterrâneo cortado por fontes ocultas, fontes que eram ouvidas, mas não podiam ser vistas". O baixo relevo também serviu como molde para que as letras fossem vazadas em parafina. Na parede podíamos ler a frase; no chão da galeria, as letras de parafina, postas invertidas, formavam um grande espelho, como se fossem na verdade reflexo do que víamos na parede. Ao olharmos para o trabalho, tínhamos a impressão de que algumas das características da água haviam sido emprestadas para o piso da galeria, como se naquele espaço estivéssemos sobre uma das fontes a que a frase se refere.

Em Comidas, de 2002, o texto estampado era uma lista de alimentos utilizados por árabes e judeus na época da criação das tribos. Neste caso

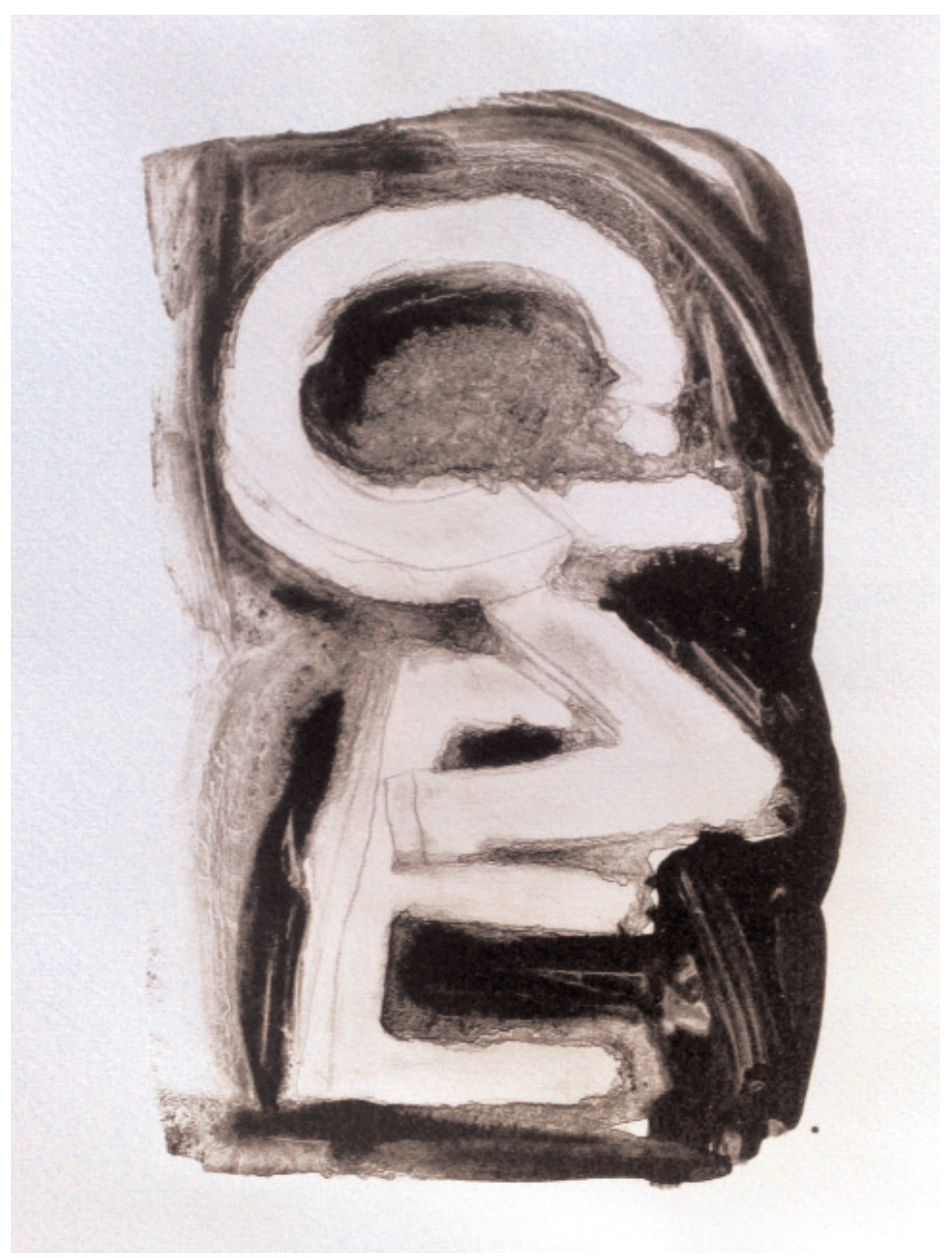


Comidas, 2006, argila e parafina, $400 \times$ $500 \times 600$ cm, exposição "Entre a Palavra e a Imagem", curadoria Paulo Reis, Fátima Lambert, Cecilia Pereira, Fund. Luis Seoane, A Coruña, Espanha. existem mais afinidades do que se costuma assumir. Além de remontar a uma mesma origem cultural, esta relação de comidas representa um ponto de equilíbrio perdido. As comidas aproximam os homens, diminuem a distâncias e as diferenças. Têm relação com o modo como as palavras são pronunciadas. Como dizia o poeta Mário Quintana, elas são responsáveis por determinar os sotaques de uma língua. No Brasil isso torna-se evidente quando ouvimos um paraibano e um gaúcho falando. Percebemos no sotaque do nordestino a farinha e o peixe se desmanchando na boca, e no sotaque do sulista a carne sendo mastigada de forma a deixá-la mais saborosa. As comidas de papa suavizam a pronúncia, quem come muita carne fala mordendo. Entre árabes e judeus, as comidas remontam a uma origem cultural semelhante, a uma mesma estratégia de sobrevivência para enfrentar as adversidades do meio. Neste caso, o jogo entre matriz e estampa, com suas semelhanças e diferenças, parece conter a mesma ambigüidade de um conflito entre culturas distintas mas com uma origem comum.

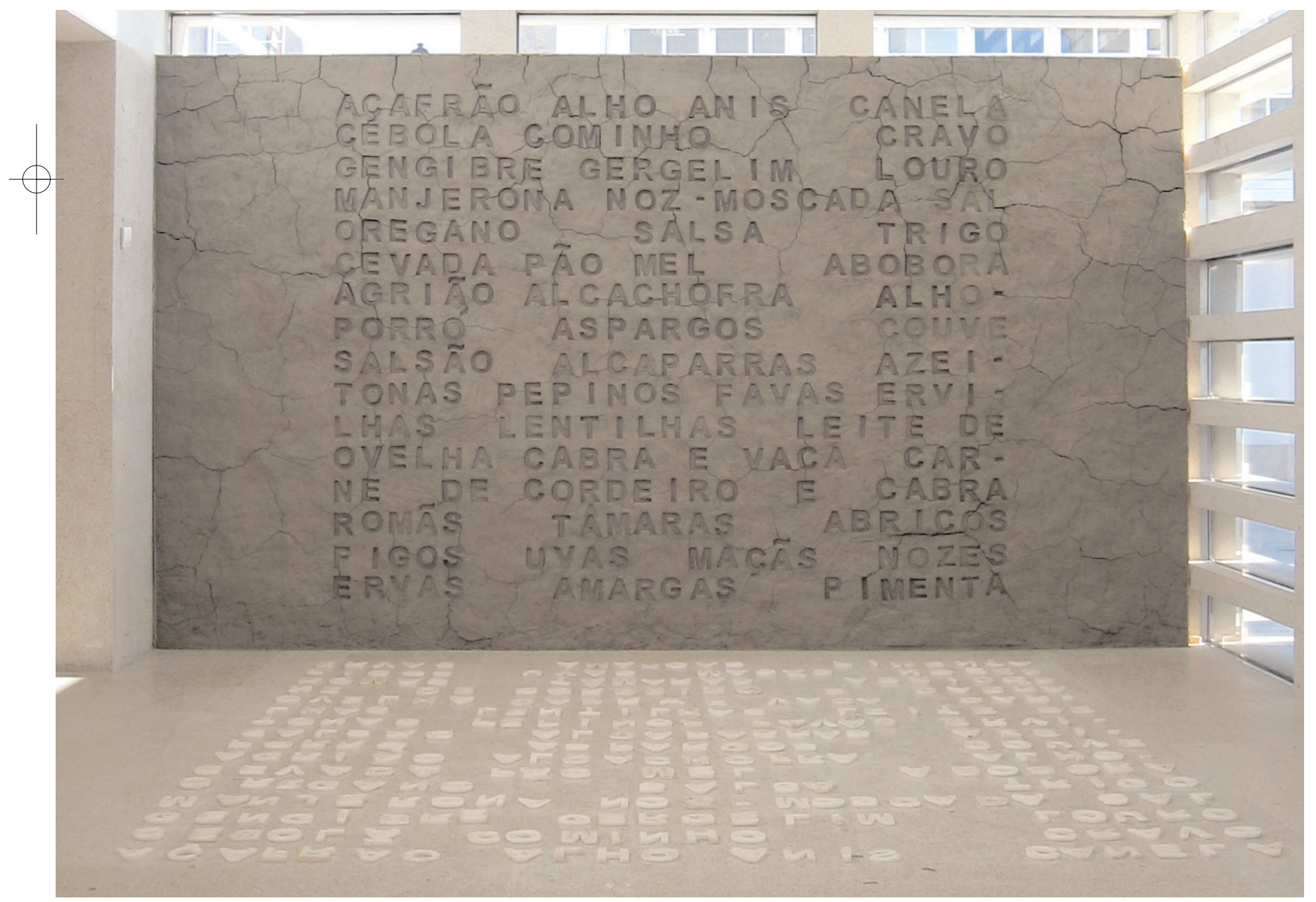


O barro cru não tem forma determinada, está alterando-se permanentemente, contraindo-se e distendendo-se, sem estabilidade alguma. Apresenta-se por aspectos temporários, em oposição à perenidade dos materiais de arte. A regularidade geométrica do texto contrasta com o provisório. A matéria em movimento entorta as linhas, desfaz a estampa, dificulta a leitura. Enquanto seca e se deforma, reafirma constantemente seu caráter transitório. Como se a superficie movediça da argila atacasse a estabilidade das palavras, destruindo seus significados, apagando a visibilidade do texto, subvertendo o sentido do que estava escrito.

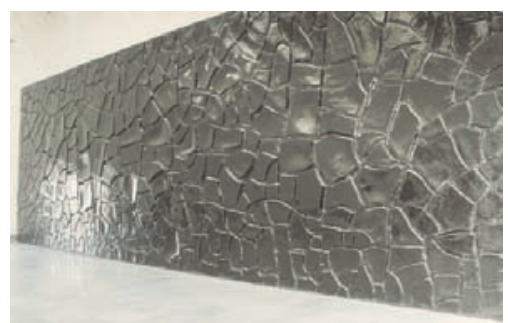

Alberto Burri, Grande Cretto Nero, 1976/77, cerâmica, $250 \times 700 \mathrm{~cm}$.

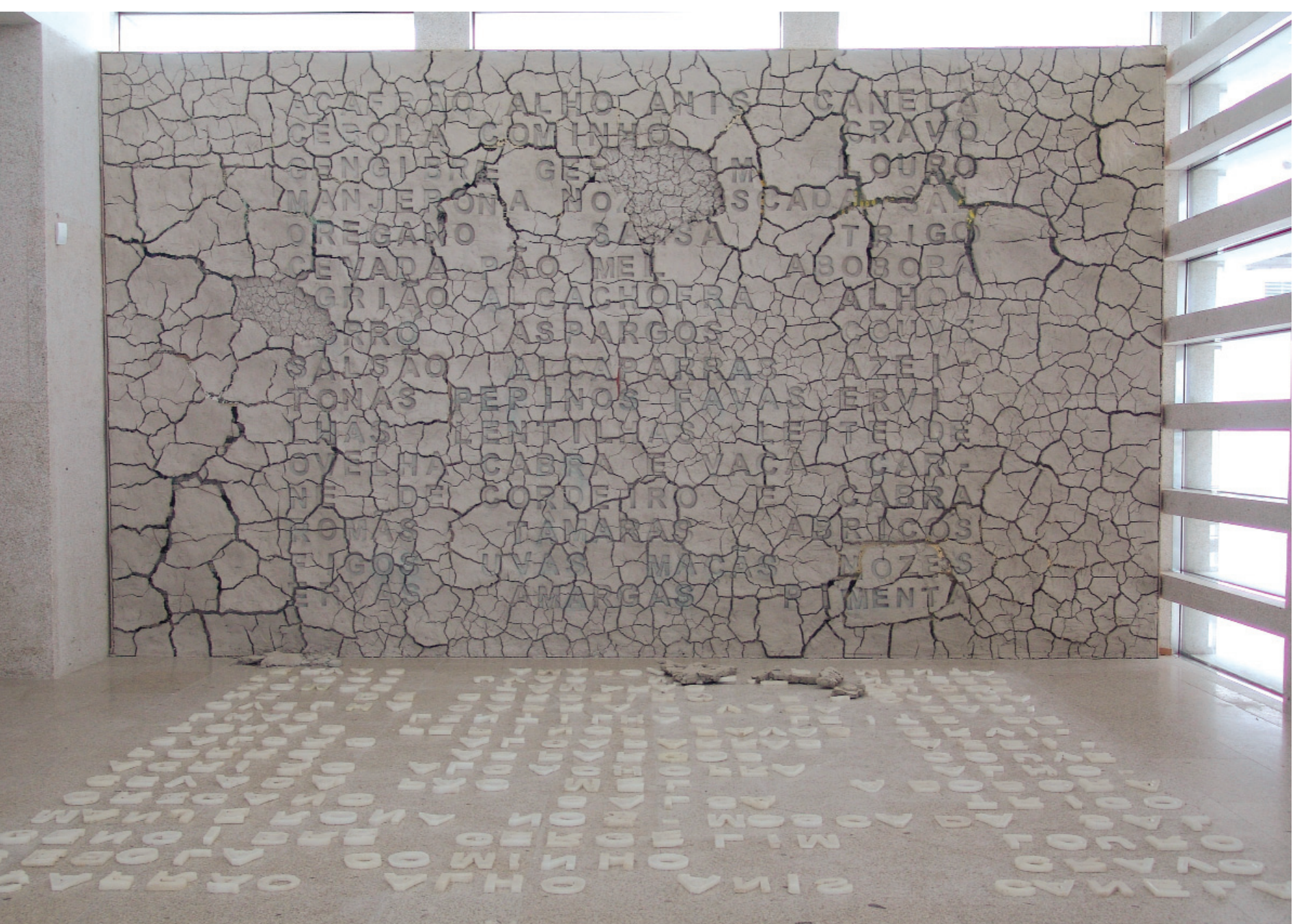




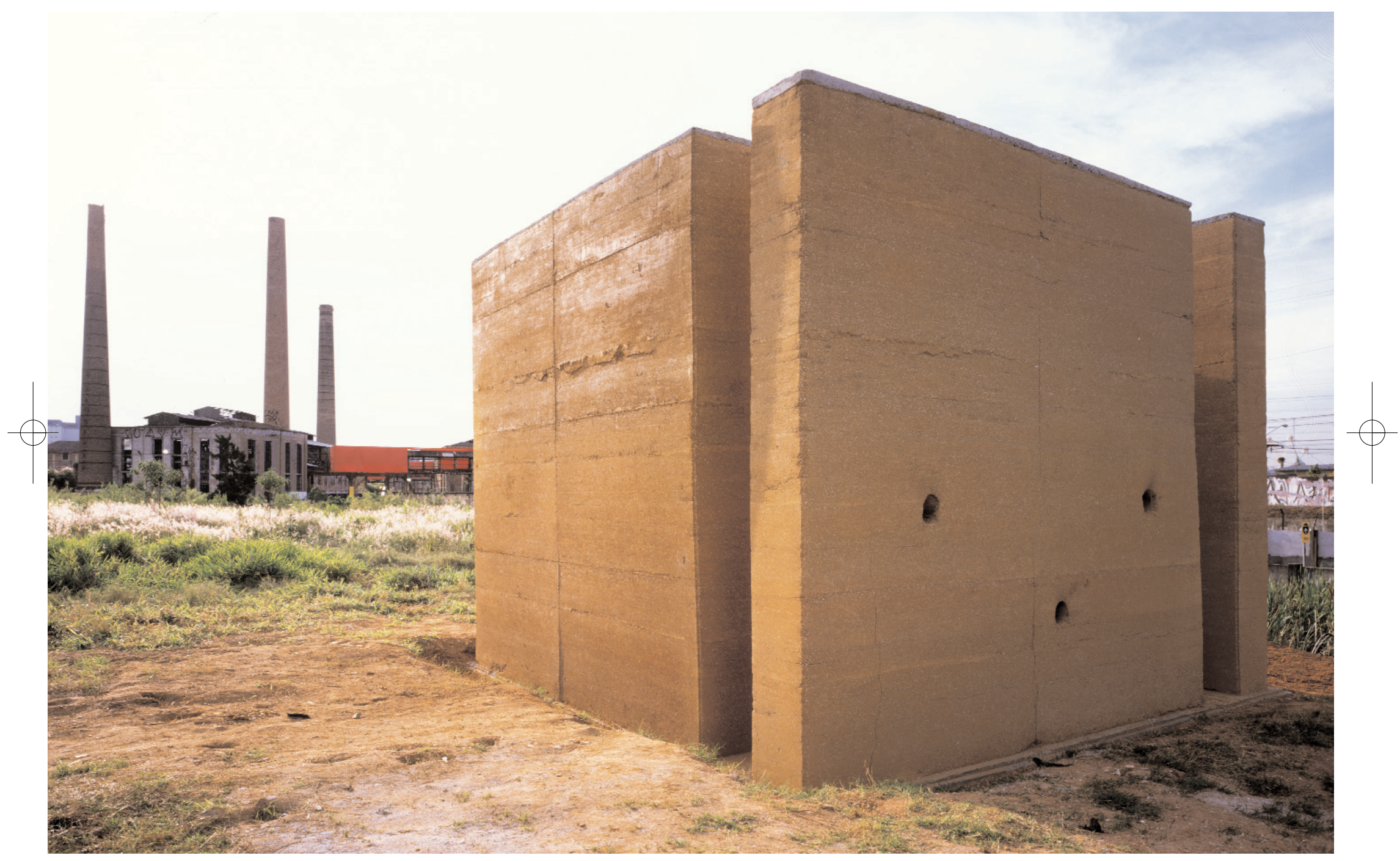

Mirante, 1997, terra (taipa de pilão) $400 \times 520 \times 520 \mathrm{~cm}$, Projeto Arte/

Cidade - Indústrias Matarazzo.

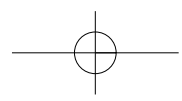




\section{Mirante}

Mirante foi um trabalho criado para a terceira edição do "Projeto Arte Cidade - A Cidade e suas Histórias", em 1997, realizado simultaneamente nas dependências da Estação da Luz, no Moinho Central e no antigo complexo industrial Matarazzo.

Escolhi a antiga fábrica Matarazzo para realizar o trabalho sem ter um projeto predeterminado. As ruínas eram solenes. Interessava-me o caráter monumental e a sobriedade dos galpões abandonados. Contudo, por mais que caminhasse pelas inúmeras salas cheias de detritos, não conseguia me decidir por um lugar para fazer o trabalho. Para mim as paredes rachadas, os telhados destroçados não permitiam uma intervenção, eram demasiados prontos, provocavam um profundo respeito. Procurava por uma ação mínima naquele espaço, que não descaracterizasse o sentido já existente ali. Aos poucos fui me convencendo de não interferir em nada, não retirar nem levar nada para lá, sequer tocar em suas paredes.

Caminhando em torno das construções, comecei a compreender o que me interessava naquele espaço, especialmente quando me afastava do conjunto arquitetônico. Apeguei-me à imagem da fábrica e à sua relação com a paisagem. A silhueta das chaminés contra o céu, a visão dos edifícios à distância, eram mais instigantes do que uma possível inserção diretamente em sua arquitetura. O recuo destacava a profundidade de campo; longe das ruínas, tínhamos uma vista em perspectiva das construções.

Por isso decidi criar uma nova construção de onde fosse possível contemplar a fábrica, e me afastar daquilo que já era determinado e forte. Em respeito à ruína procurei não retirar nem acrescentar nada ao terreno, apenas dar forma ao que já estava lá. Optei pelo processo de taipa de pilão, técnica que utiliza a terra batida em caixas para formar as paredes. A terra, materia informe, signo de horizontalidade, iria adquirir forma e pôr-se de pé. As paredes de terra remetem imediatamente a um arcaísmo e um a tempo passado. O Mirante era utópico, a fábrica já estava em decomposição.

O tema do Espelhamento está presente em vários trabalhos de maneira distinta. No Mirante esta relação se estabelece com a fábrica. A partir do confronto entre as duas construções torna-se possível perceber vínculos de semelhança e ligações por inversão. Como no espelho, aquilo que parece igual também se inverte e se distancia. Existe uma afinidade entre a ruína e as paredes de terra. $\mathrm{O}$ estado de destruição em que se encontra o edificio potencializa essas relações de semelhança. Estivesse bem conservado e ativo, talvez não se formasse nenhuma conexão entre eles. $\mathrm{O}$ encontro entre as duas construções ocorre pela deterioração da fábrica perante a estranheza do mirante. 
Olhando para a Fábrica, perguntamos: o que foi esse edificio? A fábrica perdeu sua razão: as paredes derrubadas, as portas arrancadas, móveis semidestruídos esquecidos pelos cantos, todo esse vazio evoca a sua memória. Sua monumentalidade vem da sua ruína.

Diante do Mirante perguntamos: o que é isso? Paredes existem para fechar ou delimitar um espaço e a ele estão subordinadas. No Mirante ocorria o oposto, a intenção era construir paredes, o espaço interno um "efeito colateral" disso, uma conseqüência desse agrupamento. Todas tinham o mesmo tamanho, como se fossem espelhadas. Não chegavam a se fechar constituindo uma sala, pois os cantos eram abertos. Pelas frestas podíamos ver fragmentos da paisagem. Paredes de terra preservaram o aspecto orgânico, são vivas. Se o chão, assim como o mar, são signos da horizontalidade, as paredes de taipa provocam surpresa ao dispor a terra verticalmente.

Esses vínculos entre mirante e fábrica estabeleciam-se numa relação de inversão de suas grandezas. No espelho, o reflexo se faz por similitudes e inversões. Se a matéria-prima das construções era a mesma, já a monumentalidade era distinta: uma vinha da escala, a outra remetia a um tempo ainda mais arcaico que a fábrica. Não poderia rivalizar com a grandeza dos edifícios a não ser estabelecendo uma outra escala, uma ordem invertida como no reflexo. Para criar uma contraposição a esses conteúdos, decidi implantar uma nova construção de paredes de taipa de pilão não menos sóbrias e monumentais. Se pequena em relação à fábrica, nem por isso era menos densa e grave. Somente a severidade de paredes de terra teria força para concorrer com a escala agigantada dos edifícios em ruínas. A similaridade entre as construções se fazia na sua falta de medida e de ambientação. $\mathrm{O}$ vazio e a ausência terminavam por assemelhar os edificios.

Além da semelhança entre a terra da taipa e as paredes de tijolos, há outras relações entre o trabalho Mirante e a fábrica em ruínas. As quatro paredes de terra contrastavam com a horizontalidade da paisagem, estabelecendo uma analogia com as chaminés da fábrica. $\mathrm{O}$ mesmo princípio de verticalidade também se notava no lado interno do trabalho, pelo eixo formado entre as paredes e o céu. No seu interior, para todos os lados a terra era a matéria dominante, com exceção do azul celeste no topo das paredes. Como se o céu fosse uma quinta parede, além das quatro de terra. Em alguns momentos, a sala parecia querer superar o firmamento. Em qualquer direção para onde olhássemos víamos sempre a mesma cor: terra. Somente quando olhávamos para o alto encontrávamos o azul. As quatro paredes criavam o refúgio necessário para se observar o azul do céu naquele mês de outubro.

O Mirante devia ser visto, mas também indicava uma maneira de olhar para a paisagem. Da fábrica, viam-se as paredes de terra em contraste com o 
verde da vegetação do terreno. Por outro lado, dentro das paredes de terra, através de algumas aberturas voltadas para ao edifício, podia-se ver a fábrica. Ao adentrar o espaço, havia a impressão de caminhar por dentro da obra, invertendo os pontos de vista. O trabalho dependia o tempo todo de um observador em movimento. De alguém que aceitasse o deslocamento como condição para entrar em contato com a imagem. Caminhar até o mirante e olhar a fábrica era apenas o pretexto para esse observador ideal iniciar o caminho de volta até a fábrica para olhar o Mirante.
Mirante, 1997, terra (taipa de pilão) $400 \times 520 \times 520 \mathrm{~cm}$, Projeto Arte/ Cidade - Indústrias Matarazzo.
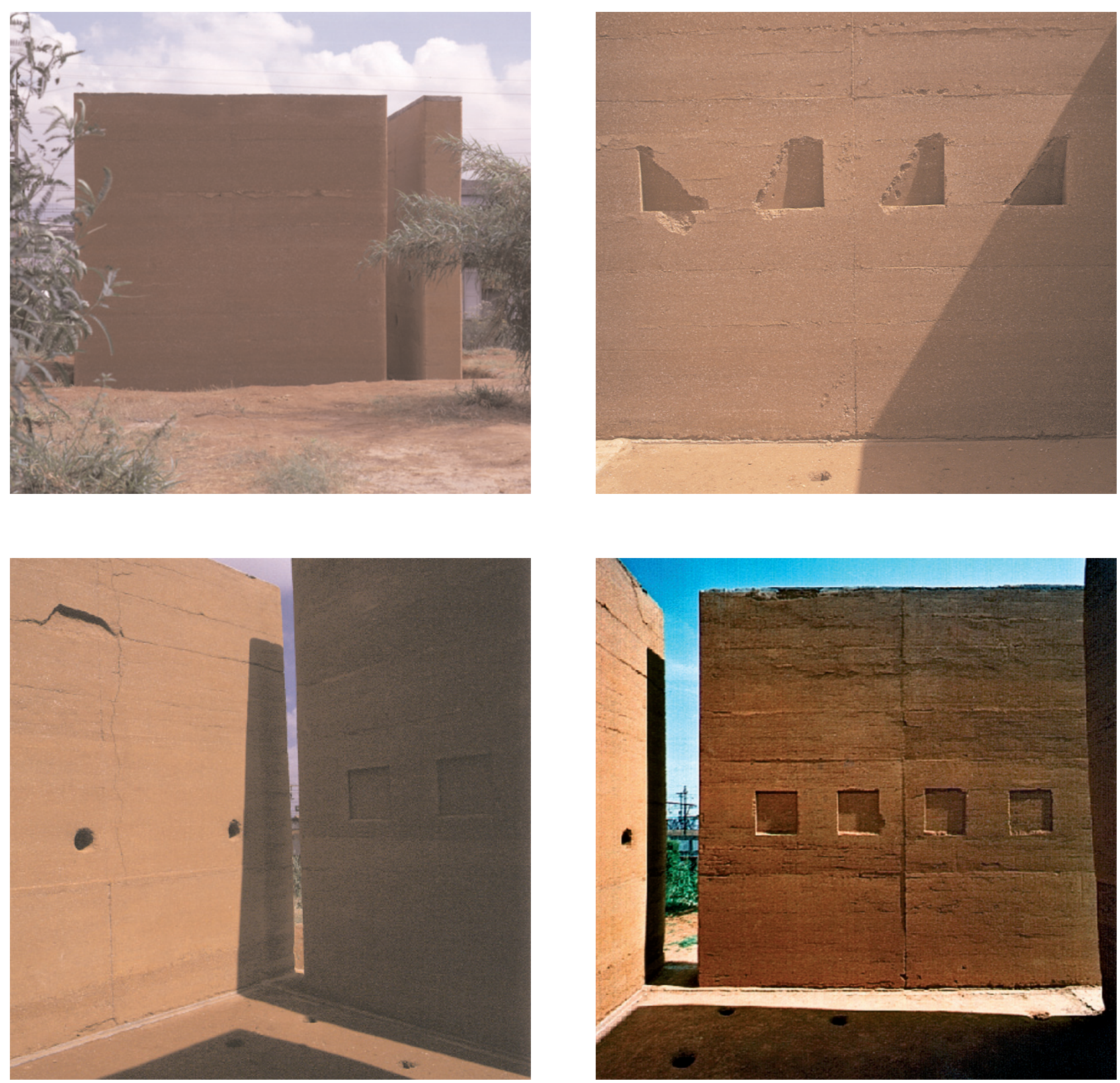


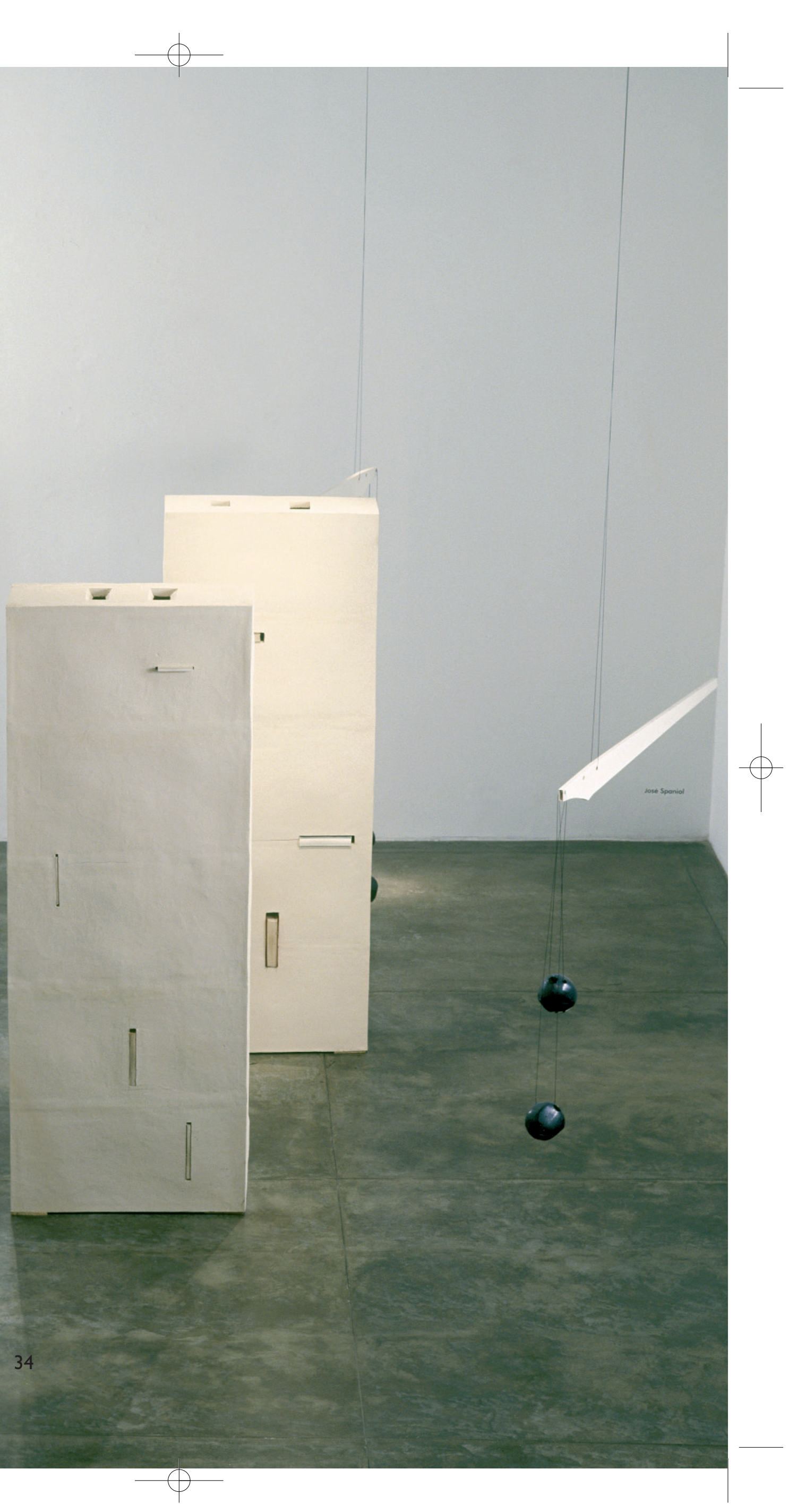




\section{Biblioteca e Balanças}

Este trabalho foi realizado durante uma residência de cinco meses no Centro Europeu de Cerâmica, na cidade de 's-Hertogenbosch, na Holanda. O projeto inicial era a fundição em porcelana das letras de parafina que eu havia usado anteriormente nos trabalhos Vitória Régia e Comidas. Pretendia explorar a transparência da porcelana, utilizando fontes luminosas na parte interna das letras. Nas primeiras semanas de trabalho, a construção dos moldes para cada letra tornou-se uma estratégia para sensibilização e concentração com o meio cerâmico. Durante esse período de adaptação ao centro, também tive a oportunidade de visitar as inúmeras casas de livros usados existentes na cidade. $\mathrm{O}$ livro, portanto, era uma presença constante no ateliê, sendo rapidamente incorporado ao processo de trabalho. Ao término de algumas semanas abandonei o trabalho de fundição em porcelana e me dediquei completamente a um novo projeto.

Este foi o ponto de partida para os novos trabalhos Biblioteca e Balanças. Inicialmente formavam uma peça única, mas posteriormente percebi que as balanças também poderiam tornar-se um trabalho independente. Biblioteca foi concebido com base no formato dos livros. Construí um sólido cerâmico regular, formado por blocos inteiriços e sem emendas. Foi modelado a partir de placas planas de argila, e em seguida montadas de modo a criar um interior oco e lacrado. Isso sempre me lembra a condição do corpo humano, remete a uma interioridade fora do nosso alcance, um espaço próximo com o qual nos relacionamos apenas por ambigüidades.

Nas duas faces há áreas rebaixadas na superficie da cerâmica, no formato de pequenas caixas. Cada uma destas aberturas foi projetada para acomodar um livro no seu espaço interno. Parece-me irônico o fato de objetos relativamente pequenos e de fácil manuseio como livros serem o razão de uma peça cerâmica de um volume agigantado. Planos e regulares, os volumes se destacam por sua verticalidade. $\mathrm{O}$ grande porte dessas peças, um pouco maiores que a escala humana, e também a sua geometria divergem da idéia comum de que a cerâmica deve ter formas orgânicas e pequeno formato. Por este motivo não identificamos a matéria de Biblioteca imediatamente, não a reconhecemos como tal. Talvez uma das principais vocações da cerâmica seja a sua capacidade de assemelhar-se a qualquer matéria, mimetizar inúmeras superficies diferentes: metais, madeiras, peles, papel, etc.

Os baixos-relevos na superficie do objeto potencializavam a massa, o espaço oco dentro da forma. Sem eles, os planos pareceriam monótonos e os volumes menos evidentes. Estas aberturas criam movimentos na superficie da peça, ordenados segundo a natureza ortogonal de sua estrutura. Sugerem um ritmo como se as aberturas correspondessem a golpes percussivos na 


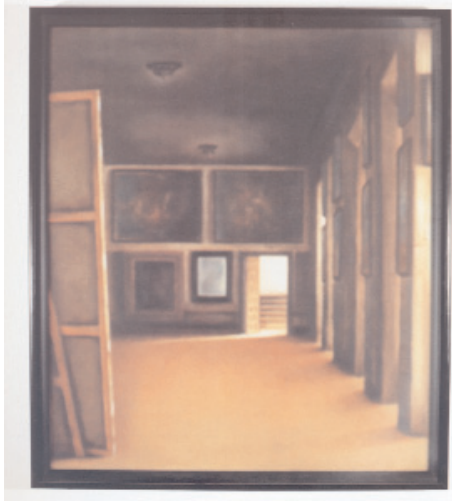

Waltércio Caldas, Velázquez, 1999. superfície cerâmica. O único movimento que foge a esta marcha geométrica é o das rachaduras provocadas pelo processo de secagem e queima. Estas poucas linhas horizontais irregulares sugerem um gesto livre, uma ironia da matéria diante do rigor da composição. Quando esticamos a argila num sentido, durante a secagem ela percorre o caminho inverso ao gesto, de volta para o princípio do movimento, como se fosse uma manifestação da memória da matéria.

Todo o conjunto é instável. Biblioteca tem, em razão de sua verticalidade, um equilíbrio frágil. Por sua solidez deveria parecer tenazmente ligada ao chão, mas sua base é pequena para dar estabilidade aos volumes. Descobri com os anos que equilíbrio e resistência são resultantes de um coeficiente entre forma e matéria. Já as Balanças, por sua natureza pendular e móvel, giravam aleatoriamente de acordo com as oscilações do ambiente. Existe um jogo entre a verticalidade das grandes peças postas de pé sobre o chão e a horizontalidade dos pêndulos no ar. Em sua leveza, as balanças pareciam levitar em torno de grandes volumes, como se gravitassem as suas massas.

Os livros são a chave para este trabalho: ora aparecem em sua literalidade, ora são notados através de sua ausência. Não estão ali para serem lidos ou identificados, relacionam-se com o trabalho por sua materialidade. Sua presença nos faz pensar sobre o espaço do livro, sobre o que é ou o que contém. Como no múltiplo Velázquez de Waltércio Caldas, as pinturas reproduzidas nas páginas do livro estão vazias, sem os personagens que a elas davam sentido.Vemos representados nas pinturas apenas o espaço. O próprio livro está vazio, os textos ali publicados a respeito das pinturas estão fora de foco, borrados, não podemos ler. Também vemos aí o espaço do livro.

Este trabalho apresentou-se diferentemente em duas ocasiões: inicialmente com os livros postos nas Balanças e numa segunda oportunidade colocados nos encaixes da superficie da Biblioteca. Na primeira vez, logo que terminei as peças no Centro Europeu de Cerâmica, os livros foram pendurados nas balanças. O pêndulo é um instrumento peculiar de medição, depende do equilíbrio e de uma compensação de forças para determinar uma grandeza. Semelhante a um espelho, onde o reflexo esta associado a um referente, na balança é a partir de um padrão fixo, que, por comparação, podemos estabelecer uma medida. Os livros apareciam pendurados as Balanças, amarrados em fardos, suspensos no ar como contrapeso. Numa espécie de aferição subjetiva, o que parecia estar sendo medido era seu conteúdo e não o seu peso. Sem os livros as pequenas aberturas na superficie da Biblioteca ficaram vazias. Víamos nos baixos-relevos apenas o espaço desocupado onde eles deveriam estar.

Em outra oportunidade, na galeria Nara Roesler, em São Paulo, foram encaixados na superficie das grandes peças e as Balanças tinham apenas 
pêndulos cerâmicos ovais. Sem os livros, as balanças ficaram menos conectadas às Bibliotecas, evidenciando que os livros faziam a conexão entre os objetos. Encaixados nos baixos-relevos, não podíamos ver sua lombada, não sabíamos qual livro estava ali, nem seu assunto, nem seu autor. Os livros neste caso estavam ali como matéria e como potência aprisionada no interior da peça. Não era possível identificá-los, mas participavam da composição preservando seus conteúdos, mantendo sua integridade - suas folhas transformavam-se em planos.
Biblioteca e Balanças, 1999, cerâmica e livros, medidas variáveis, Centro

Europeu de Cerâmica.
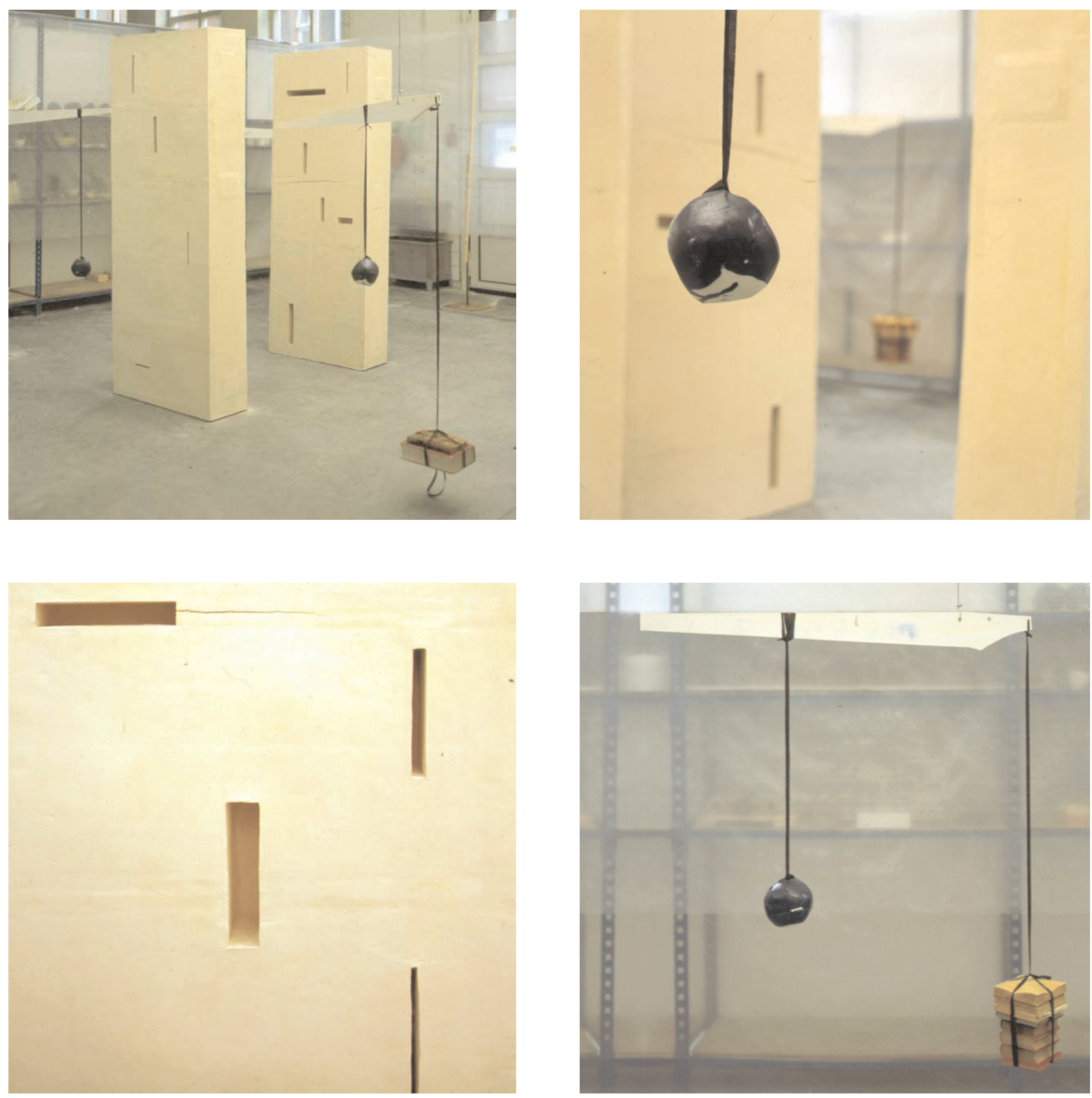
Teto Chão, 2002, latão e mármore,

medidas variáveis, Galeria Nara Roesler.

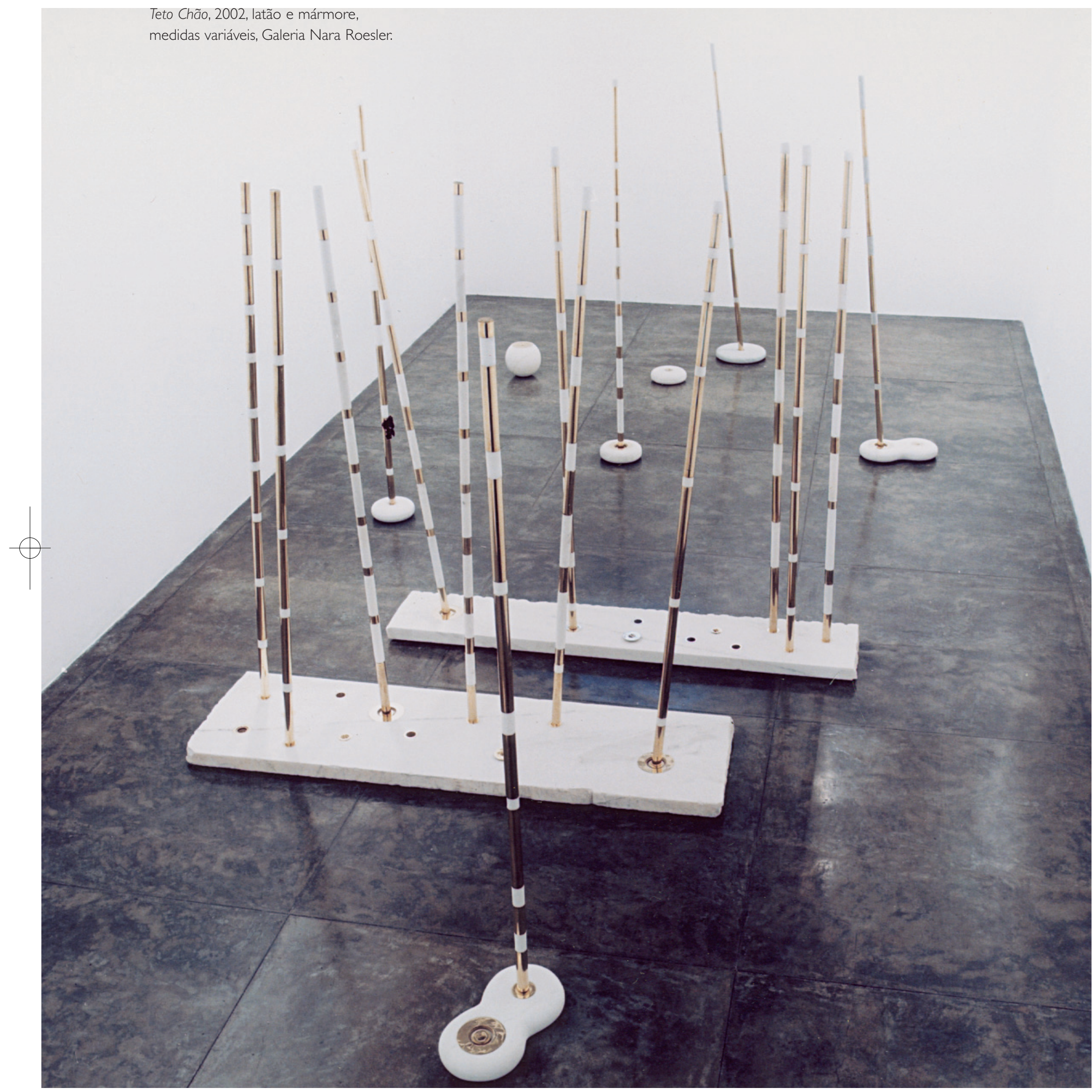




\section{Teto Chão}

\section{As Duas Chuvas}

Primeira: no meio da atmosfera parada havia uma matéria tão fina quase imperceptível, era admirável que pudesse cair, e ao cair nos surpreendia ainda mais, pois o fazia estendida como um fio de prumo. Não seria uma surpresa se flutuasse aleatoriamente em trajetórias imprevisíveis. E, para tornar tudo ainda mais caprichoso, caía feito régua. Somente quando a brisa soprava sem alterar a geometria da sua queda, inclinava-se ligeiramente para um lado e outro em ângulos de cinco graus.

Segunda: no meio do sertão, no interior brasileiro, depois de meses de seca, a chuva não consegue tocar o chão. Após a longa estiagem, a atmosfera quente e seca não permite que a água se precipite completamente. Durante a queda se condensa, evapora e volta a subir. Em baixo, durante este período de suspensão, em que a água se esforça para cair, percebemos apenas uma brisa fresca.

Mais do que referências para o trabalho Teto Chão, essas duas histórias fazem parte do meu imaginário e demonstram uma maneira de olhar. Revelam para mim um pouco do mecanismo pelo qual um elemento comum é incorporado ao universo sensível. Mesmo tentando recuperar a origem do acontecimento poético, entre o cotidiano e a realização do trabalho, muitos elos se perdem. Noto uma aproximação com alguns trabalhos da história da arte, por uma identidade com certos conteúdos: ritmos, formas, proporções, sentidos de ocupação do espaço, etc. O ritmo das hastes, em Teto Chão esclarece a minha afinidade pela pintura Batalha de São Romano, de Paolo Uccello, e pela pintura Rendição de Breda, de Diego Velázquez. Trata-se de um processo que se desenvolve a partir de uma ordem interna. Atribuo, por exemplo, a este território repleto de lacunas, o fato de uma obra realizada com matérias pesadas como mármore e latão referir-se a conteúdos tão opostos como suspensão e leveza. Em Teto Chão, através dessa operação poética ou de uma força visual latente, as lanças mostravam-se ligeiramente separadas do solo, apontadas para o alto, pareciam levitar desligadas do chão, como se a forma procurasse dissimular o peso da matéria. Associo este confronto entre leve e pesado a um mecanismo semelhante ao reflexo; no espelho tudo está invertido, como se os espelhos sempre estivessem na contra-mão. Noto que muitos trabalhos surgem dessa aparente contradição: sobriedade e leveza, maciço e instável, etc.

As peças de mármore e latão distribuídas pelo espaço da sala apresentavam um duplo sentido de ocupação: por meio de uma visão panorâmica, era possível notar uma razão de conjunto; por outro lado, através de uma

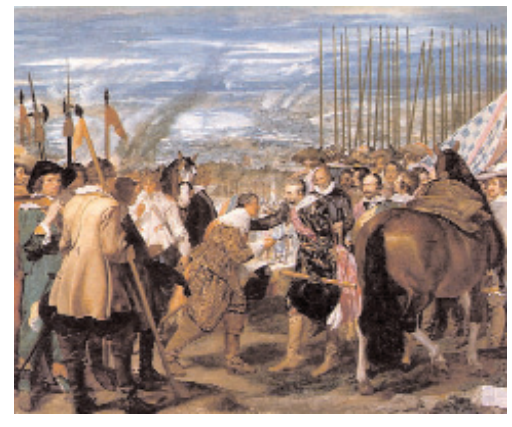

Diego Velázquez, A rendição de Breda, 1634, óleo sobre tela, $307 \times 367 \mathrm{~cm}$.

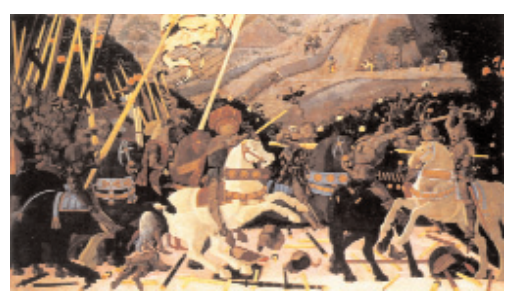

Paolo Uccello, Batalha de São Romano, I450s, tempera on wood, $182 \times 320 \mathrm{~cm}$. 


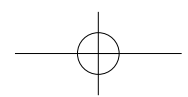

5 Max, Roberto Burle. Arte e Paisagem - conferências escolhidas, 1987, Nobel.

autonomia do objeto em relação ao ambiente, percebíamos o sentido individual de cada peça. Essa múltipla possibilidade de combinação dos elementos acrescentava ao conjunto um sentido lúdico. Como num jogo, as hastes podiam ser posicionadas de múltiplas maneiras dentro da sala, concentradas de modo a criar um núcleo ou diluídas pelo espaço de acordo com a composição.

A intenção deste trabalho foi criar uma ocupação vertical: as hastes tinham a função de tomar conta do plano e também do volume da sala. Procuravam eliminar todo o espaço vazio, inclusive pela aproximação do teto com o chão, definindo um eixo de ligação da parte de cima com a de baixo. As lanças destacavam um ponto de fuga na sala, potencializando uma profundidade virtual no espaço. Numa conferência sobre a paisagem, Burle

Teto Chão, 2002, latão e mármore, Max afirma que as palmeiras marcam os intervalos no espaço, destacando a medidas variáveis. perspectiva e com isso sinalizando as profundidades de campo. ${ }^{5}$

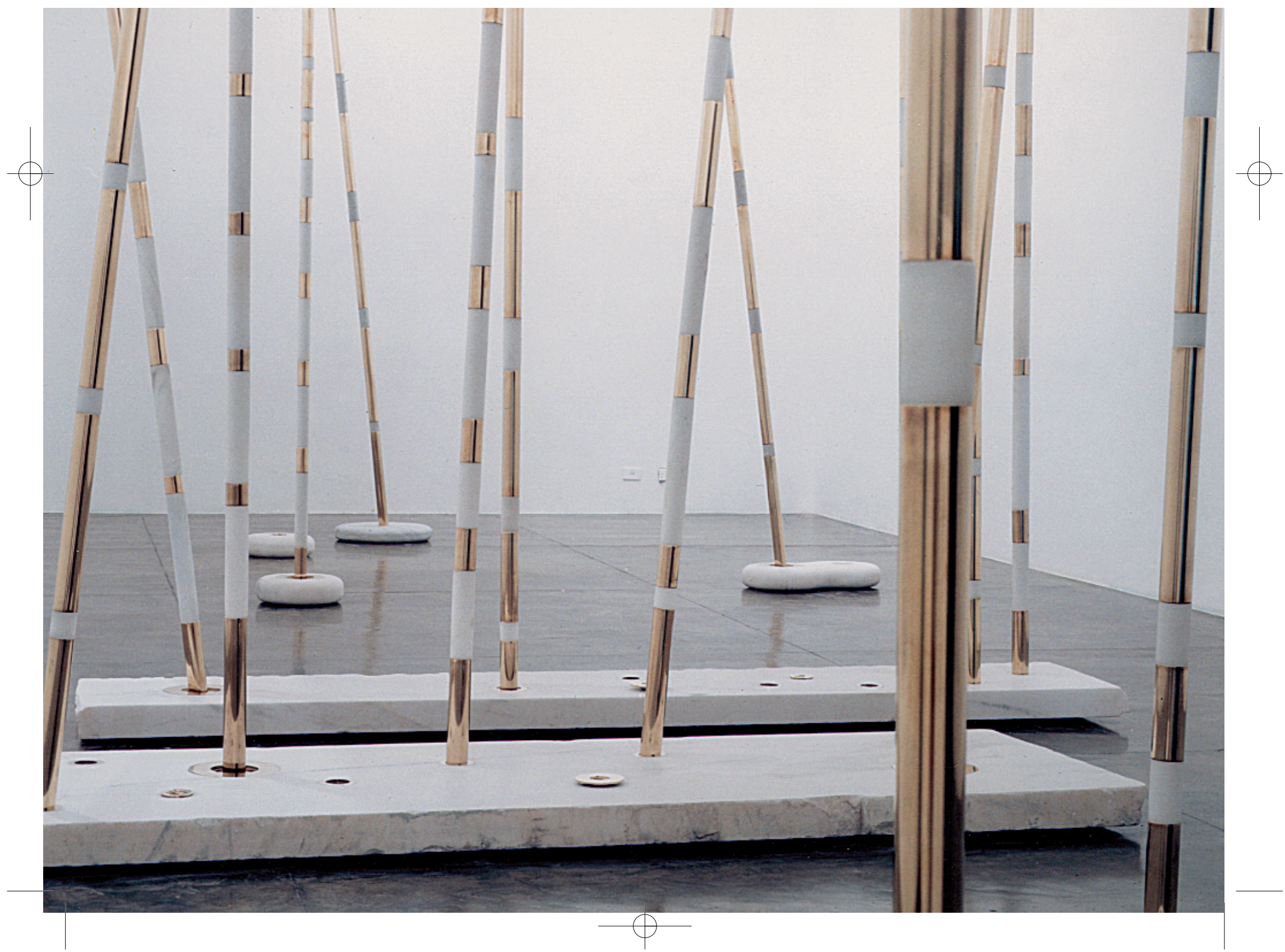




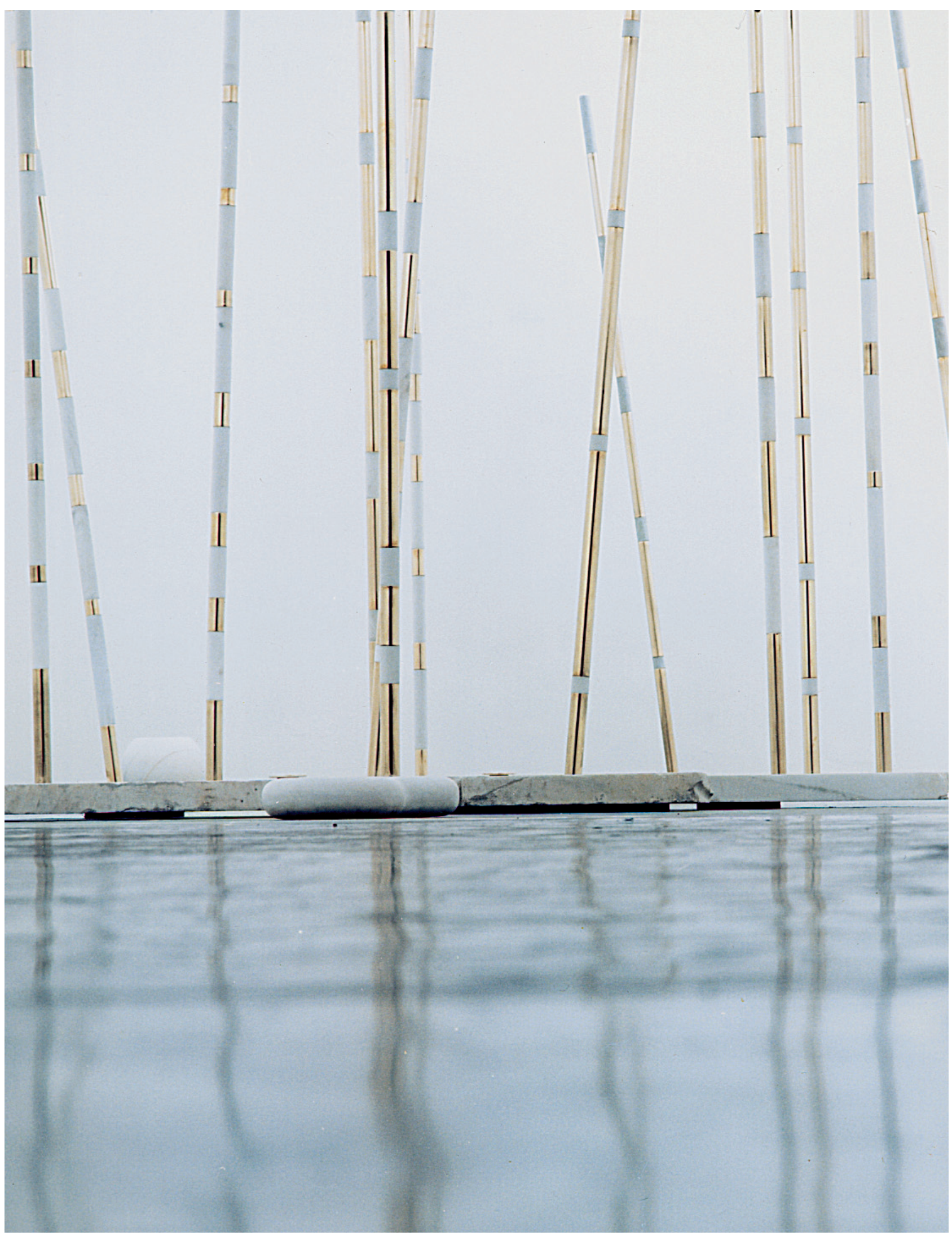




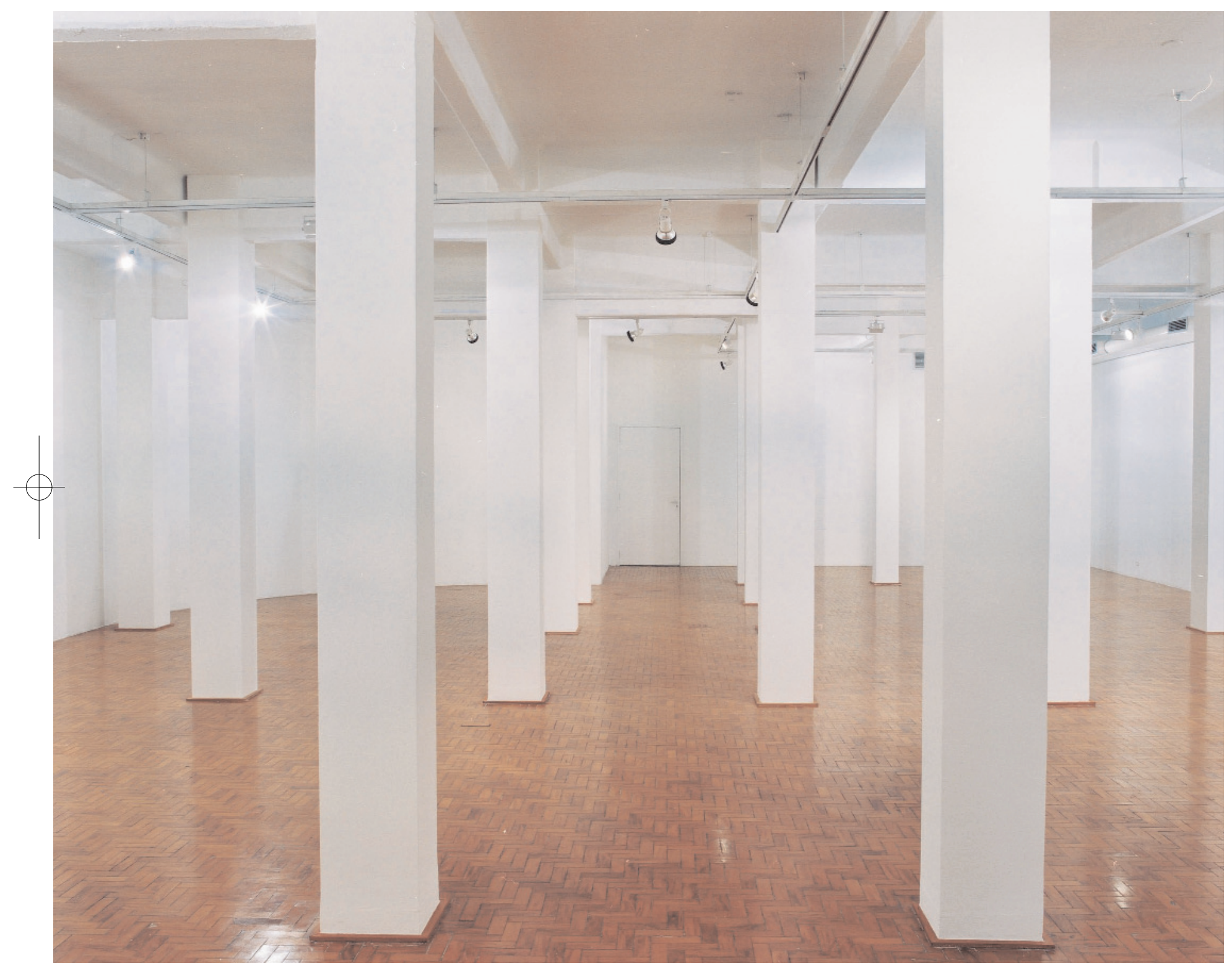

Colunas, 2003, gesso, medidas variáveis, Centro Universitário Maria Antônia, USP. 


\section{Colunas}

Sempre me intrigaram pelo seu posicionamento as colunas no Centro Universitário Maria Antônia, da Universidade de São Paulo. Pela falta de simetria parecem postas aleatoriamente dentro do espaço, independentes das funções estruturais que devem cumprir dentro do prédio. As seis colunas são posicionadas em pares, mas não é possível identificar entre elas uma razão comum para o conjunto. $\mathrm{Na}$ frente, os pares são colocados em linha como jogadores em um campo; mas, no sentido longitudinal, não existe alinhamento entre elas. As duas últimas no fundo da sala ficam completamente soltas no espaço, como volumes isolados e sem correspondência. Não há regularidade entre elas, inclusive não têm as mesmas medidas.

Para a instalação Colunas, foram colocadas mais 25 cópias idênticas e precisas, junto das seis colunas estruturais já existentes na sala. Justamente a falta de simetria entre os pares serviu de padrão para o posicionamento das novas reproduções. O que era exceção tornou-se regra.

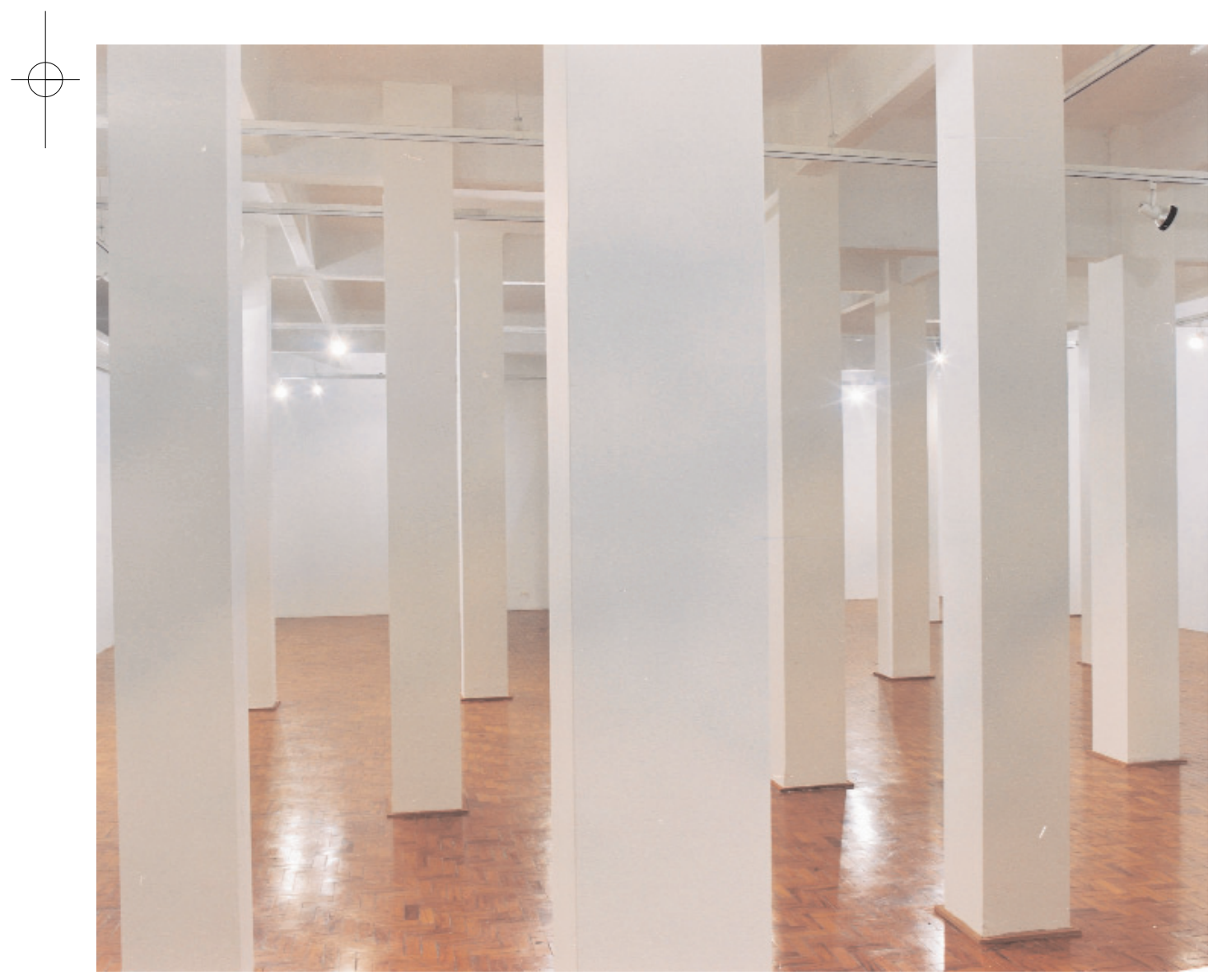


6 Como relata José Ortega y Gasset, em seu "Bosque", as árvores visíveis estão ali apenas para encobrir as que não podemos ver, o bosque seria justamente esta parte oculta (Ortega y Gasset, José. Meditações do Quixote, Livro Ibero, Lisboa, 1967.

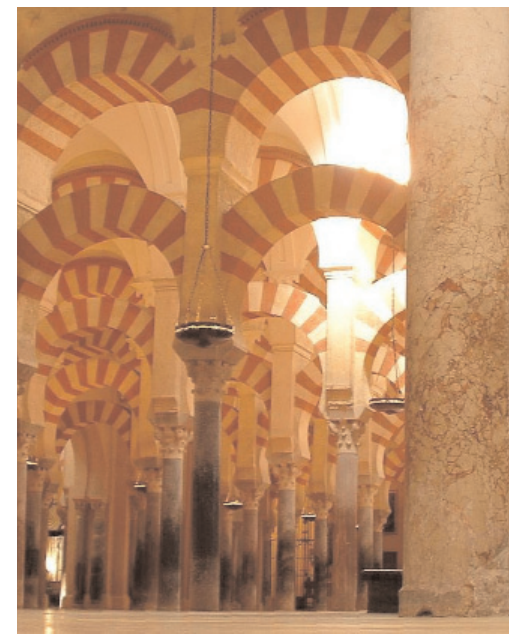

Grande Mesquita de Córdoba, Espanha.
Neste trabalho era imprescindível o deslocamento para a concretização da experiência estética. Somente através do movimento, um observador poderia perceber que os intervalos no espaço acentuavam o vazio. Desse modo, ao caminharmos, as colunas tornavam-se pontes para o olhar, agregando à nossa visão uma dimensão tátil. Não era possível abarcar o ambiente por inteiro, havia sempre uma parte da sala que se mantinha oculta. Intervalos enormes ficavam escondidos criando vários pontos cegos. A partir de determinados ângulos, a porção visível do espaço era menor do que a parte escondida. Completávamos o ambiente sempre por partes e somente na imaginação formava-se uma visão do todo. Ao encobrir uma parte do ambiente, as colunas criavam um espaço de latência ${ }^{6}$. Dessa fragmentação, surgia um sentido de unidade, como se o olhar tocasse a sala de porção em porção.

As seis colunas originais se destacam por interromper a continuidade do espaço da sala, limitam os pontos de vista possíveis e interferem no que está sendo exibido. Dificultam a montagem das exposições, obrigando frequientemente a se adotar uma lógica contrária à das obras. Para se obter um sentido de unidade, é necessário um esforço para se desviar das posições comuns, mantendo a interferência dentro de um limite razoável. Nesta instalação as colunas tornaram-se o foco principal da exposição. $O$ efeito resultante com a colocação das 25 novas unidades foi inesperado. À medida que a ocupação evoluía, deparava-me com o imprevisível. O que deveria tomar o espaço foi somente o artificio para nos depararmos com o vazio. O trabalho só se mostra realmente durante a execução, mesmo aqueles que parecem inteiramente resolvidos no projeto, nos colocam diante do imprevisível e somente quando vão para o espaço, revelam sua verdadeira natureza poética.Os intervalos ganhavam destaque diante do elemento arquitetônico e o foco foi transferido para o ambiente. Quanto mais a sala era subdividida, mais se enfatizava o espaço e menos se viam as colunas. Como se a matéria emprestasse sua visibilidade para o ambiente e o olhar estabelecesse uma relação tátil com o espaço. Não era a matéria que estava sendo mostrada, mas o vazio em torno dela. Ao final as colunas tinham um papel secundário na formação desse ambiente e cumpriam apenas a função de sinalizar as subdivisões. A sala me fez lembrar da atmosfera presente em alguns espaços religiosos, onde o vazio se faz presente e parece nos acompanhar, como na Grande Mesquita de Córdoba, na Espanha.

Percebi que era possível ampliar a profundidade do campo, criando um primeiro plano com intervalos maiores e no fundo aumentando a concentração de colunas. Com este artifício, a sala se prolongava valorizando o ponto de fuga, aumentando a sua profundidade. Como havia ocorrido anteriormente com as lanças, utilizei uma ocupação semelhante à do trabalho Teto Chão. As colunas multiplicadas pela sala criavam 
imediatamente a sensação de espelhamento. Enquanto desenhava o trabalho, ponderei sobre a utilização de um espelho ou uma lâmina de vidro para potencializar a duplicação do espaço através do reflexo. Mas logo se tornou evidente que o jogo estava em dar corpo ao que era virtual, trazer o reflexo para o campo da matéria, estender para o espaço aquilo que normalmente pertence ao plano.

Se a duplicação das colunas criava sensação de espelhamento e aumento horizontal do espaço, também destacava um eixo vertical presente na sala. $\mathrm{O}$ que sustentavam aquelas colunas? Qual a natureza da massa existente sobre a sala? Só pude formular estas perguntas após ver o trabalho pronto, revelando talvez um dos principais sentidos da instalação. Sem dúvida matéria muito densa e pesada para que tanto apoio fosse necessário. Quanto mais colunas eram postas no espaço, mais ele se esvaziava e projetava para o topo da sala um enorme volume virtual. Como se o vazio dentro do ambiente e esse volume imaginário estivessem sujeitos a uma mesma lei de proporção. Ao multiplicar as colunas pela sala, optei por construir fisicamente algo semelhante ao reflexo no espelho. Curiosamente, a tentativa de materializar o que normalmente é virtual criou a oportunidade para que o espaço de latência se transferisse para o alto da sala.

Em 2007 recriei a instalação Colunas para o museu da Fundação União Fenosa, na cidade da Coruña, na Galícia. O sentido desta vez foi completamente diferente, a sala não era completamente fechada de modo a isolar o espaço. Optei por uma montagem que se apoiasse também no espaço vazio da sala.

Nesta exposição reuni uma série de trabalhos de épocas diferentes: os textos espelhados no chão de Vitória Régia e Comidas, as cadeiras e fotografias da série $O$ Descanso da Sala, trabalho que ainda vou comentar a seguir. Em todos eles, o assunto espelhamento aparece como o foco central do trabalho. 


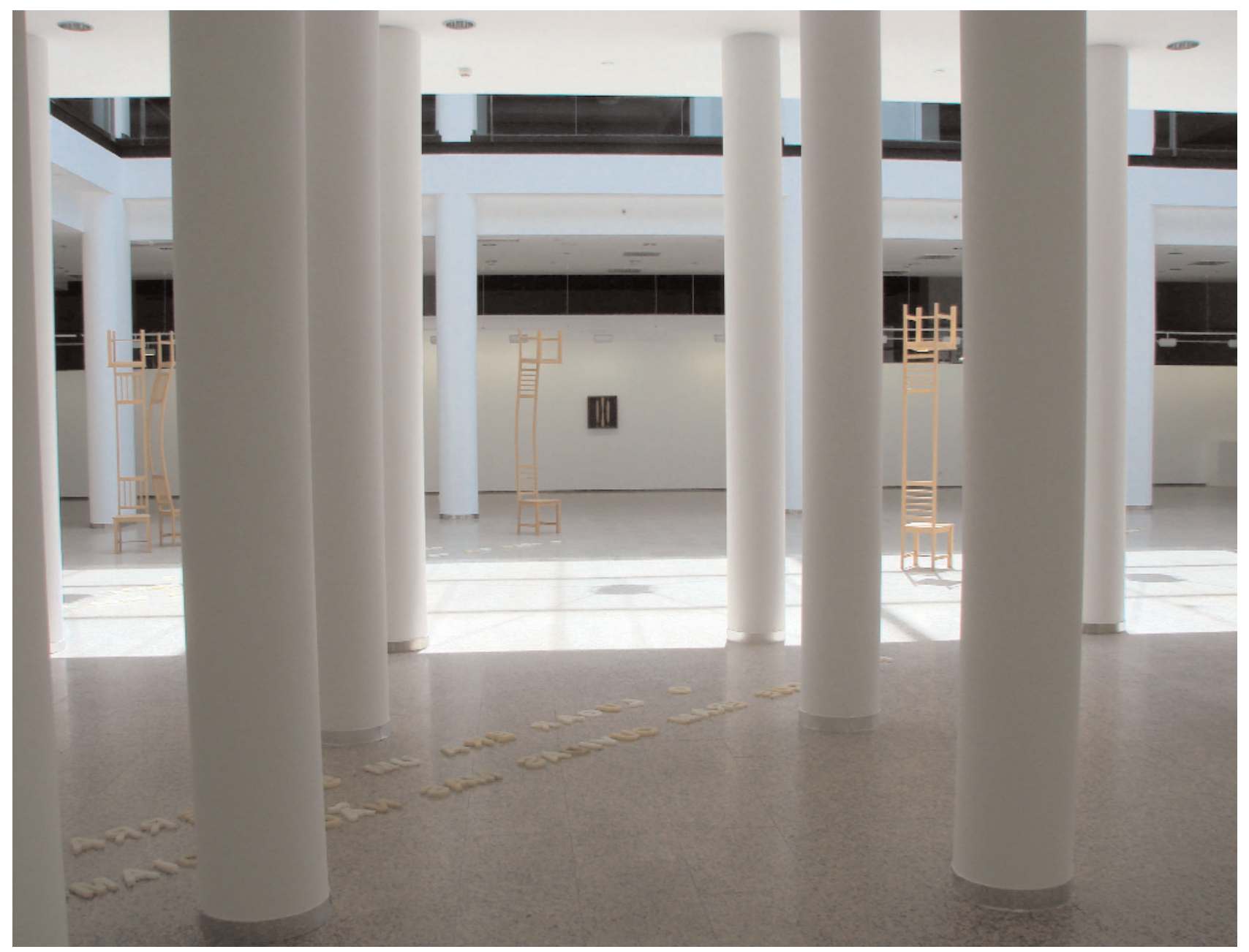

Colunas, 2007, medidas variáveis,

Museo de Arte Contemporâneo União

Fenosa, A Coruña, Galícia. 


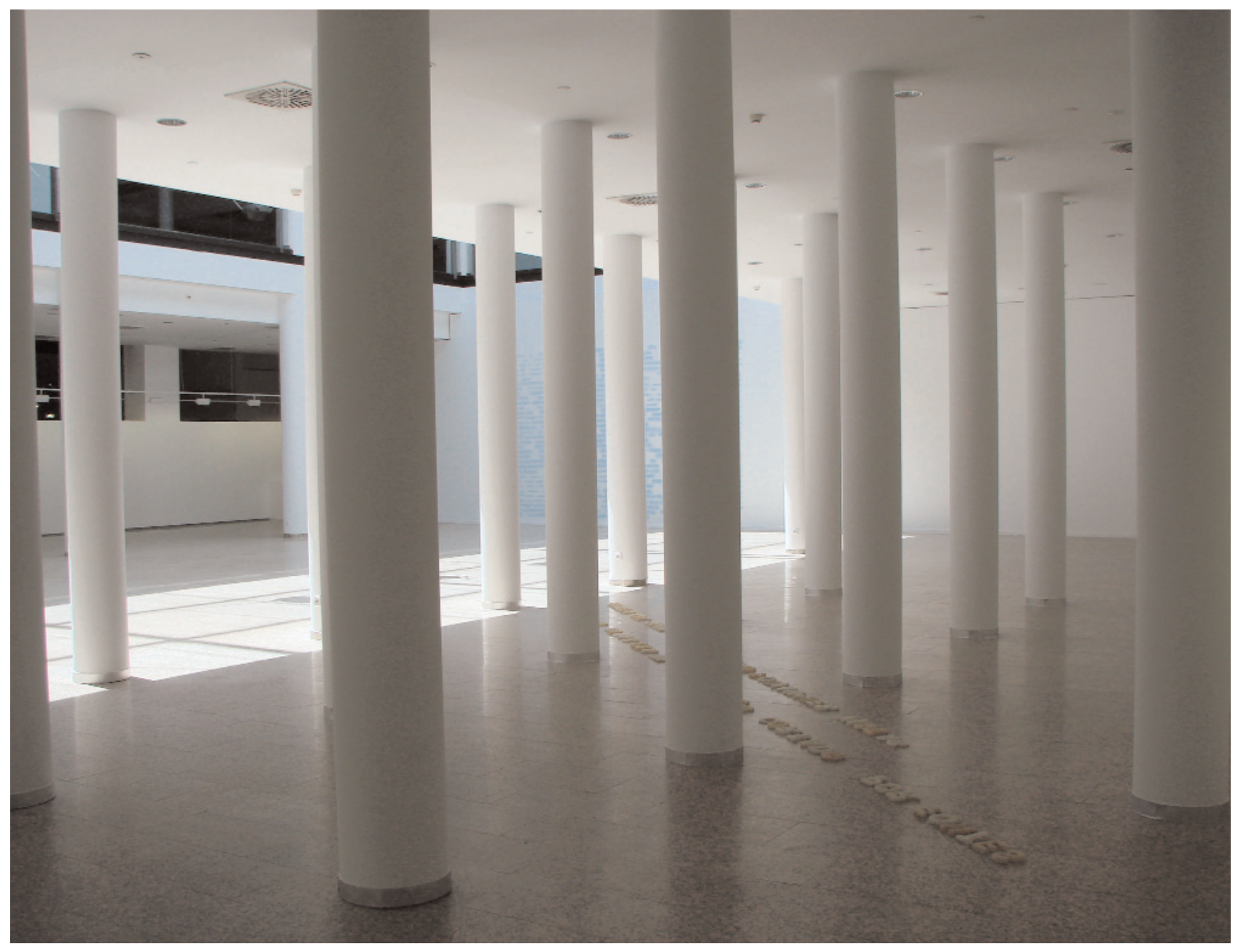




\section{A Casa e o Bosque}

No meio das árvores vemos, a uma altura de aproximadamente 7 metros, o que seria uma sala ou um quarto pendurados de cabeça para baixo. Uma estrutura de concreto sustenta o conjunto: uma cama, uma mesa, uma escada e duas cadeiras. Fixados no topo dessa armação, os objetos são refletidos sobre um espelho de água, dessa maneira projetados contra a copa das árvores e o céu. Mediante esse artifício, recuperam sua posição natural.

Um visitante andando pelas alamedas do bosque decerto não perceberia a estrutura de concreto e os objetos no meio das copas das árvores. Entraria em contato com o trabalho ao olhar para a superficie da água, e em seguida poderia ser surpreendido pela imagem de uma sala flutuando entre as árvores e contra o céu. Ao olhar para o alto, perceberia objetos comuns

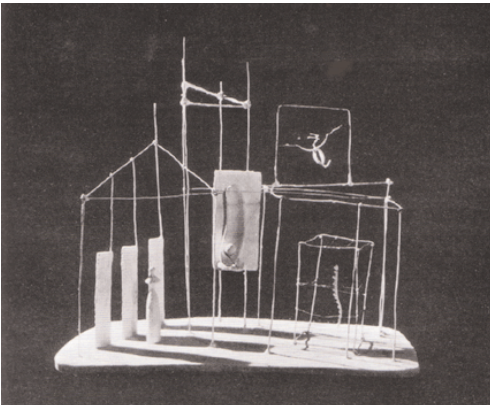

Alberto Giacometti, O Palácio às 4 da manhã, 1932, madeira, vidro, arame e barbante, $63,5 \times 72 \times 40 \mathrm{~cm}$ pendurados junto às árvores, no meio da clareira. Poderiam estar em qualquer ambiente de uma casa normal. Um ponto de vista improvável surge ao olharmos para eles. Podemos observá-los invertidos como se o mundo tivesse perdido a normalidade. Somente quando olhamos para a imagem refletida na água é que a sala volta a colocar-se na sua posição habitual, embora flutuando contra o céu, longe de seu cotidiano. O trabalho estrutura-se por esse eixo entre terra e céu, num movimento vertical de aproximação entre opostos. Como numa ascensão, os objetos abandonam suas funções e se projetam para outro plano.

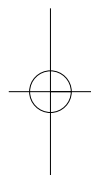




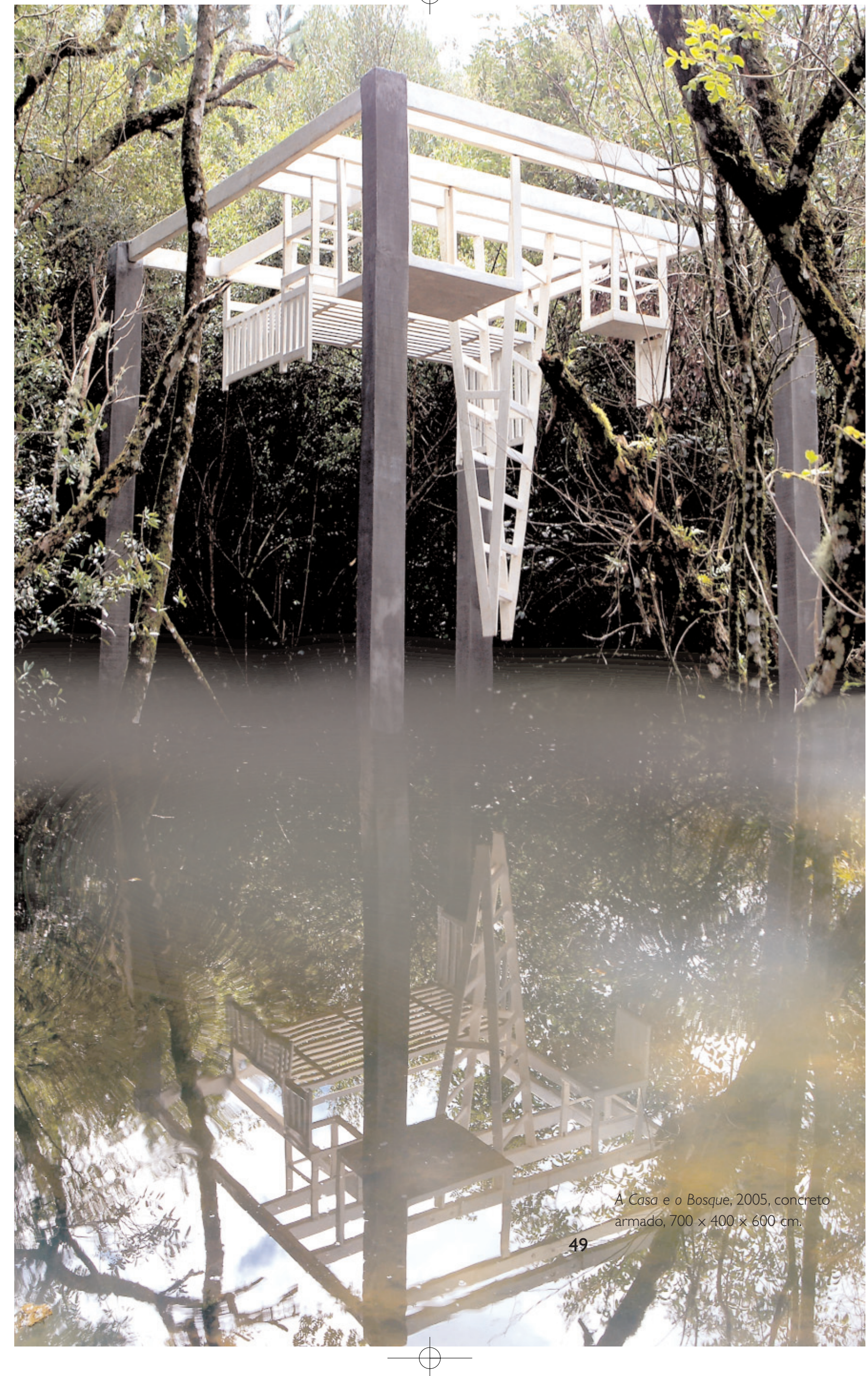




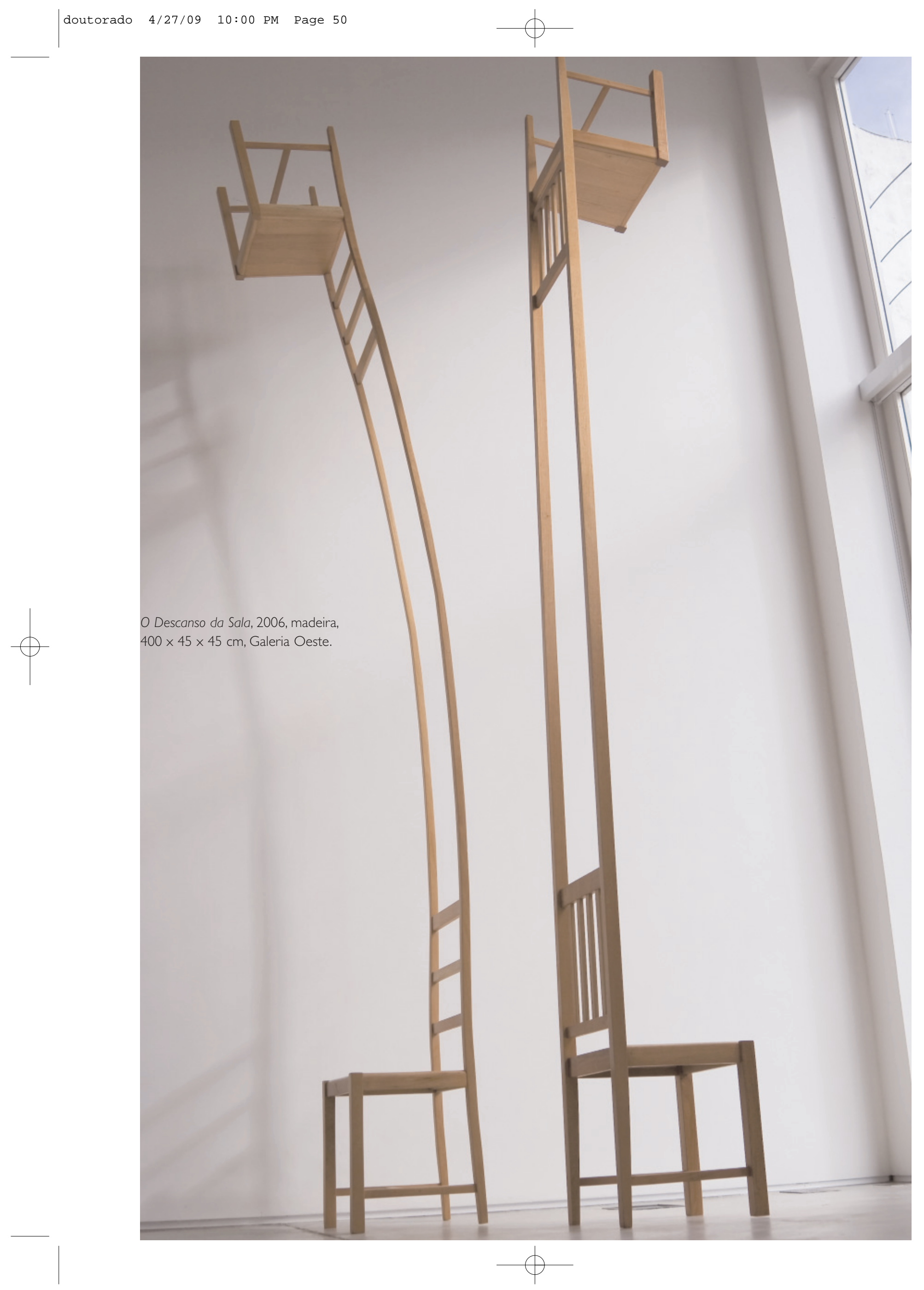




\section{O Descanso da Sala}

Em O Descanso da Sala o reflexo da imagem adquire materialidade. A série é formada por objetos de madeira que se duplicam em direção ao alto, bem como de fotografias de sombras projetadas contra o chão. Utilizo aqui o mesmo repertorio de $A$ Casa e o Bosque. Mas neste caso a projeção dos objetos não é mais a imagem refletida no espelho d'água. Mediante o prolongamento das peças, o reflexo também é construído materialmente dando origem a um objeto duplo. A repetição da forma confere às peças um aspecto paradoxal e ambíguo: um jogo entre materialidade e reflexo. Os assentos das cadeiras, o tampo da mesa, o leito da cama e os degraus da escada flexionam-se para o alto, dilatando ao extremo seu próprio volume, como se estivessem à procura de uma outra dimensão. Nas fotografias, em contrapartida, as sombras devolvem invariavelmente esses mesmos objetos para o chão, fazendo com que as formas se dobrem de volta para plano, como se durante a queda, banidas do mundo tridimensional, se tornassem silhuetas ${ }^{7}$.
7 “'Os objetos de José Spaniol, em particular aqueles realizados em madeira e com quatro metros de altura, conservam a domesticidade das aparências ao mesmo tempo em que efetuam uma ligação entre o céu e o chão. E ao procederem desse modo, ao estabelecerem contato com esse espaço secreto, o que provavelmente acontece todas as noites, renovam sua carga de mistério, aquela mesma que faz com que, às vezes, sem que saibamos por quê, olhemos desconfiados para eles, ressabiados pela certeza de que sejam habitados por sombras". Farias, Agnaldo. Catálogo da exposição $O$ Descanso da Sala, 2006.

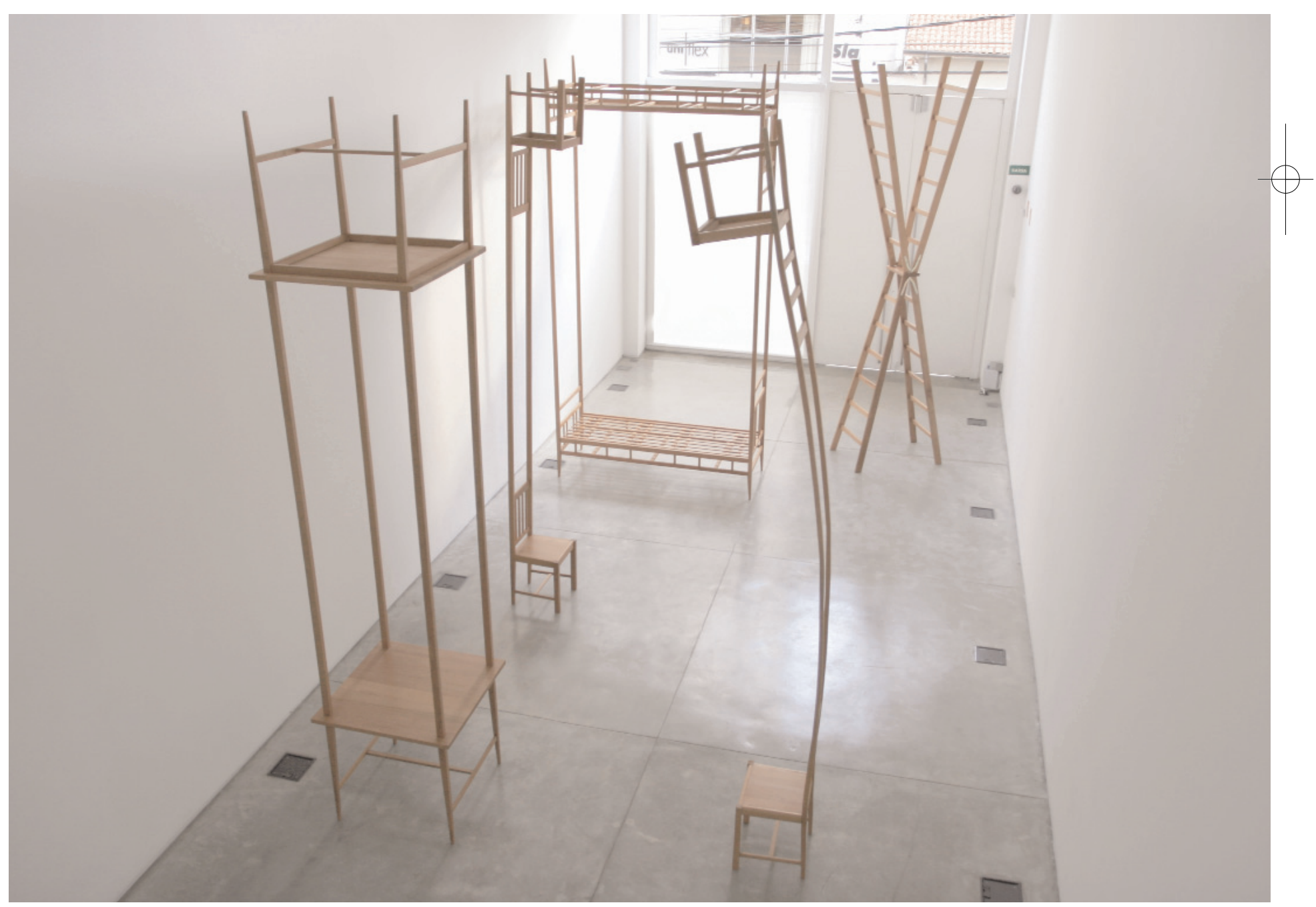




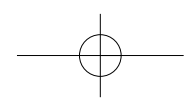

Existe uma instabilidade semelhante à da natureza morta: pratos, talheres, pães estão sempre esquecidos no limiar de uma mesa. As cadeiras nos dão a impressão de que estão prestes a cair. Que foram abandonadas aleatoriamente por alguém distraído que passou por ali há pouco. Sua permanência nesse plano elevado parece estar continuamente em risco, sua estabilidade sempre provisória. Neste esforço de elevação atingiram o limite das suas energias.

A imagem da queda ronda a cena, algo está sempre próximo a desabar, se não forem os objetos talvez o próprio espaço. As peças nos obrigam a olhar para cima, criam um eixo vertical e nos impõe um distanciamento. Quando olhamos para baixo, o objeto está sempre perto, quase volta para o mundo trivial e familiar.
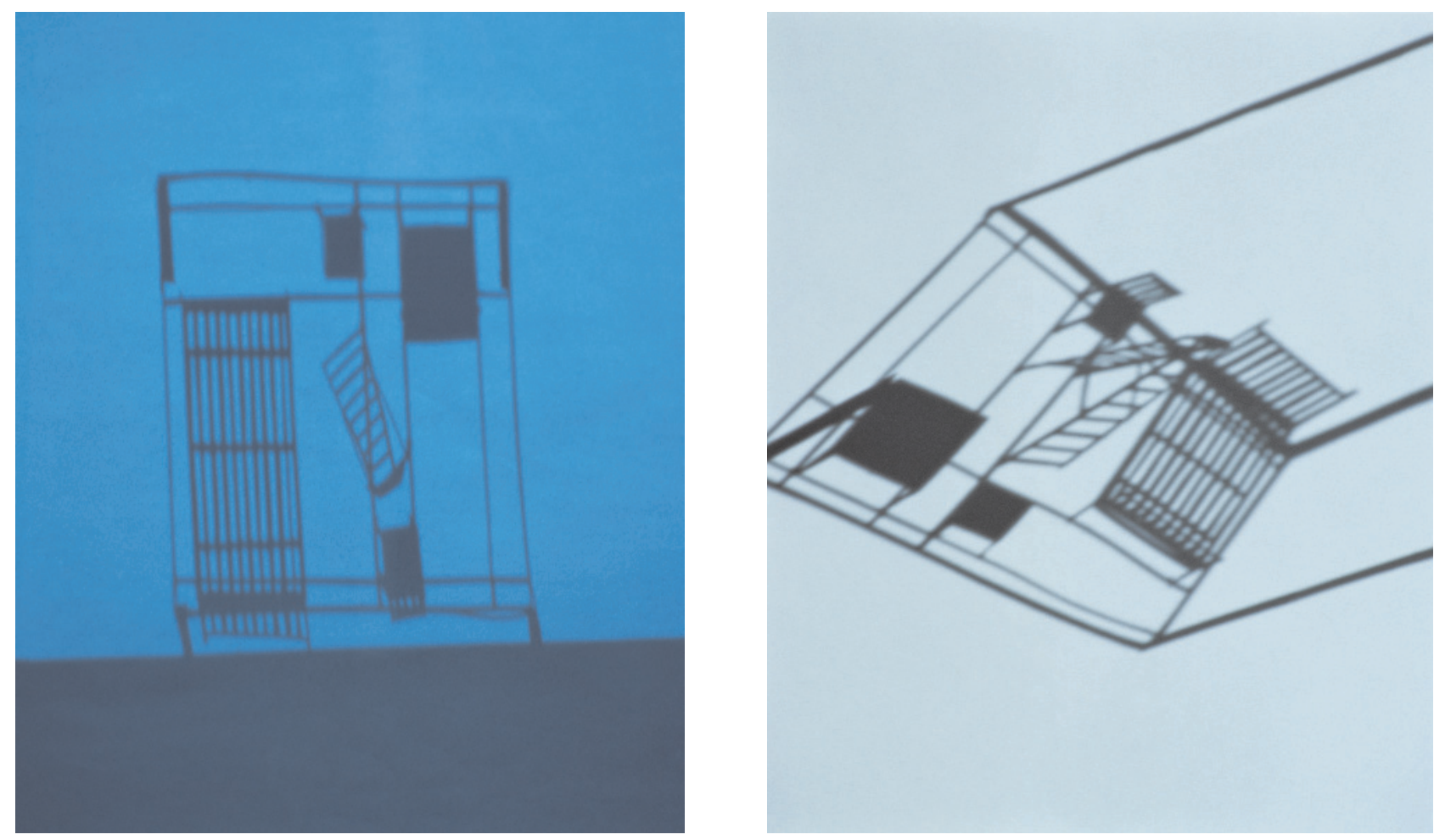

O Descanso da Sala, 2006, fotografia, $155 \times 125 \mathrm{~cm}$. 


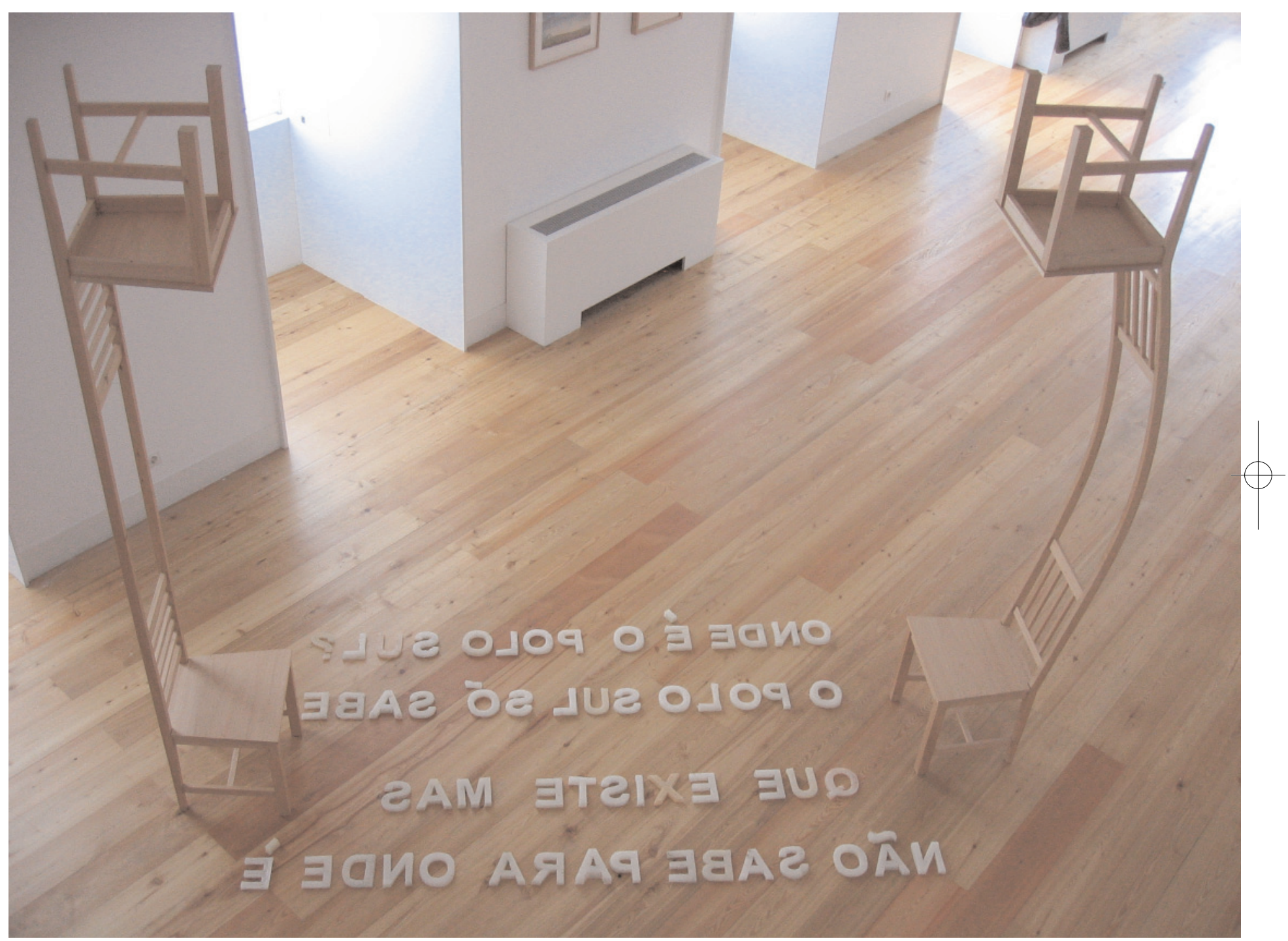

Cadeiras, O Descanso da Sala, 2006, série reunindo esculturas e fotografias de tamanhos variados, "Entre a Palavra e a Imagem", curadoria Paulo Reis, Fátima Lambert, Cecilia Pereira, Centro Cultural Vila Flor, Guimarães, Portugal. 


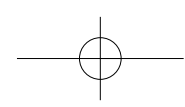

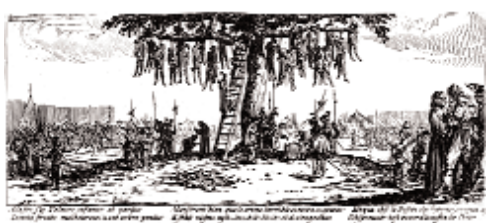

Jacques Callot, Les Grandes Miseres, A Árvore dos enforcados, 1633, gravura em metal, $8 \times 13 \mathrm{~cm}$.

8 Gosto muito da gravura de Jacques Callot (1592-1635), da proporção das figuras humanas em relação ao espaço (casas, praças, clareiras e árvores).

Através do vazio em torno das pessoas entramos em contato com a imensidão da paisagem. As pequenas gravuras ecoam. Pendurar as Balanças nas árvores me fez lembrar da gravura Árvore dos Enforcados.

Desenhos, 2008, grafite sobre papel, estudos para Balanças e Lousas penduradas nas árvores.

\section{Balanças e Lousas}

Em 2008 e 2009 iniciei uma série de trabalhos, a partir de uma variação em pedra das Balanças. Simultaneamente movido pela textura e cor escura da ardósia, também comecei uma série de desenhos (pastel sobre pedra) que chamei de Lousas. As novas Balanças sustentam pequenos quadros de pedra em contrapeso com letras de parafina. Pretendo pendurar outros objetos nas balanças, colocar os quadros de pedra em equilíbrio com cadeiras, escadas, letras e palavras, objetos do meu repertório recente. Quero ajustar esses grupos de objetos no alto das copas das árvores, a uma distância que mantenha as balanças separadas do observador. É o chão que nos permite estabelecer uma medida em relação ao mundo. No alto e à distância perdemos as referências do espaço ao nosso redor, os objetos passam a habitar um espaço de vertigem. É ai que pretendo colocar os objetos. ${ }^{8}$

Lousas tornaram-se para mim um diário, também uma espécie de acelerador de imagens. Por intermédio delas experimento vários caminhos diferentes para cada composição. Os desenhos avançam e recuam muitas vezes, transformam-se continuamente, nunca estão prontos. Faço sobreposições alterando os temas, utilizando partes dos desenhos anteriores ou apagando tudo com água. As Lousas ficam ao ar livre, no pátio do ateliê, sujeitas as mudanças de tempo, da luz do dia, ao frio e ao calor.

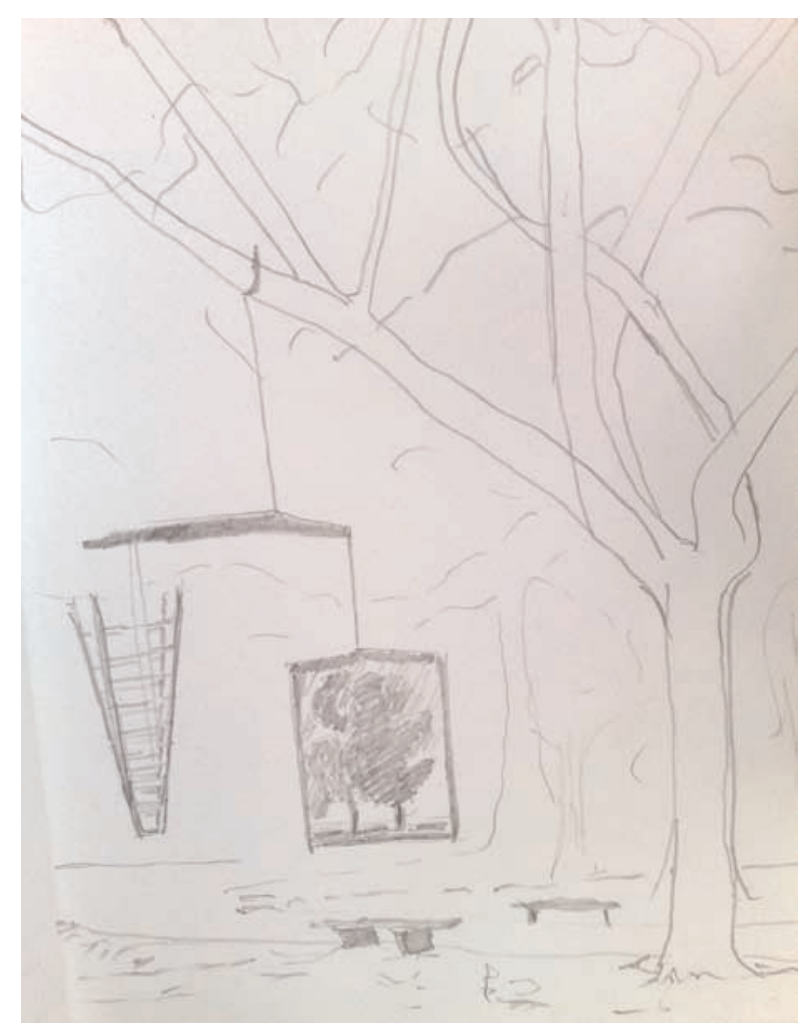

54

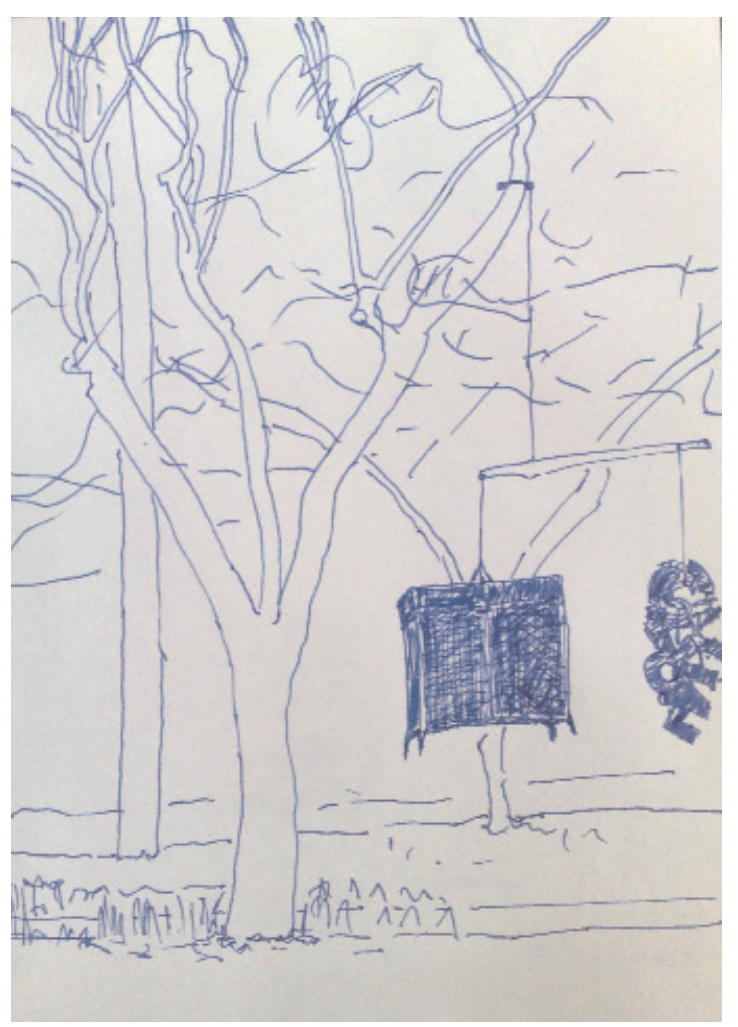




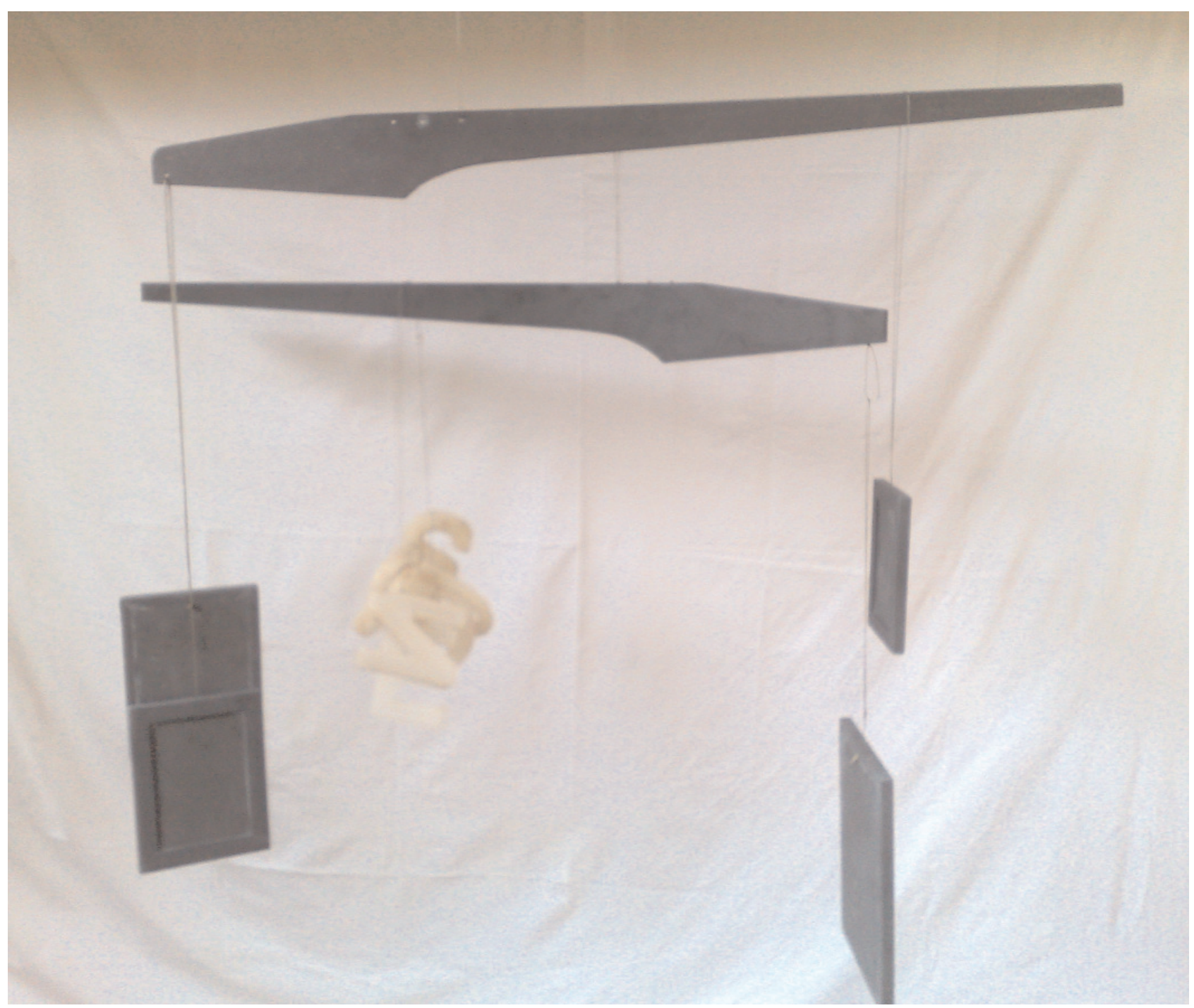

Balanças, 2008, pedra e parafina, dimensões variadas. 

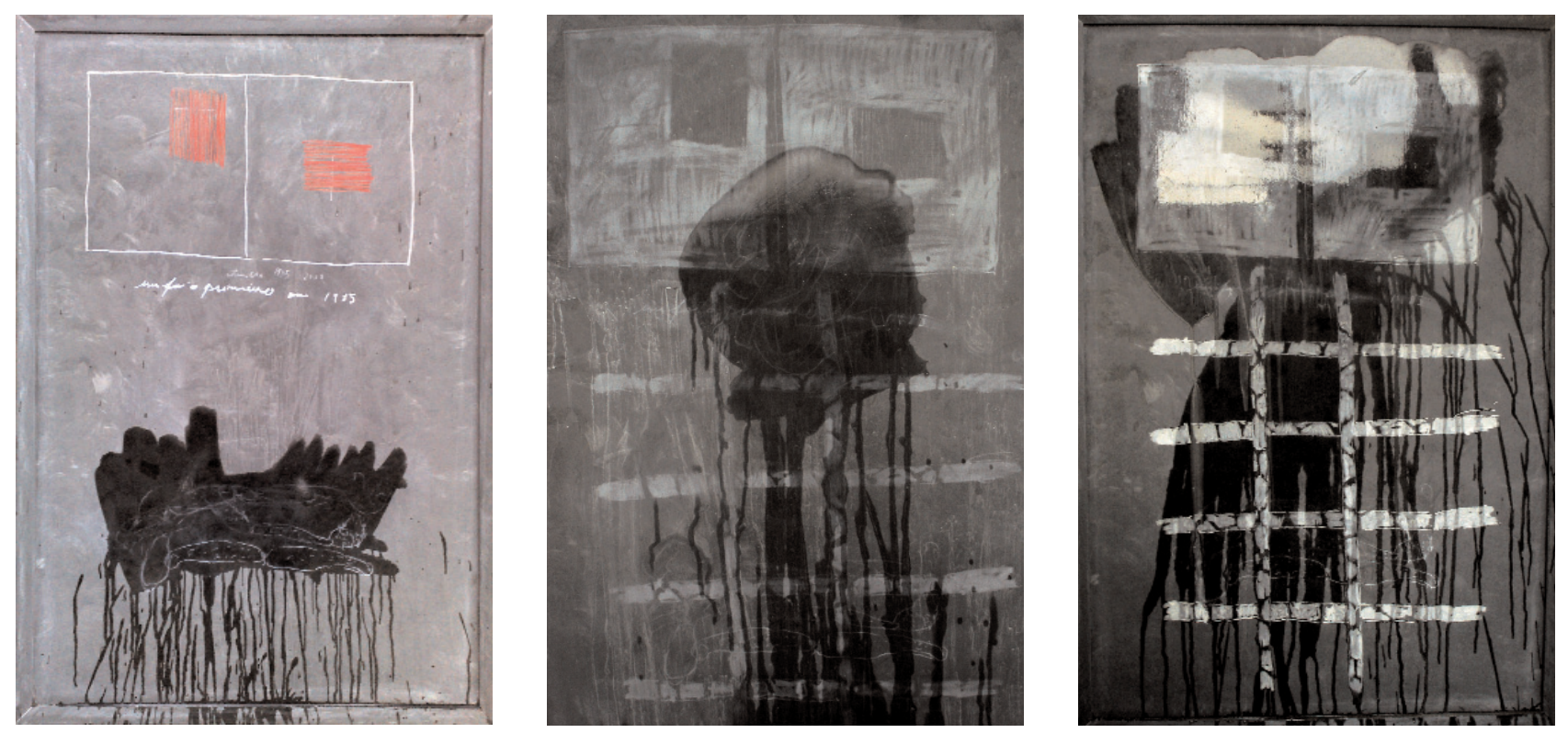

$\theta$
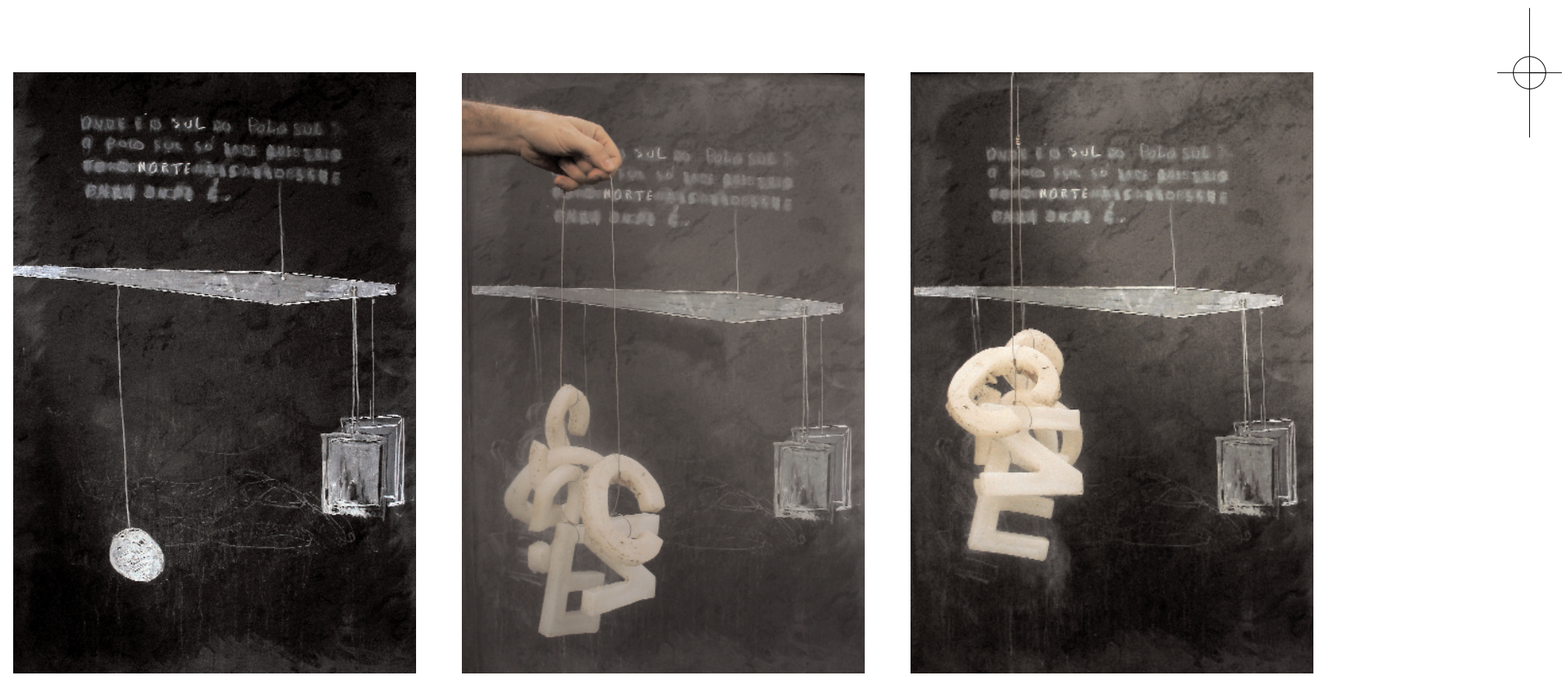

Lousas, 2009, pastel sobre pedra,

$98 \times 135 \mathrm{~cm}$

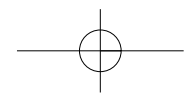



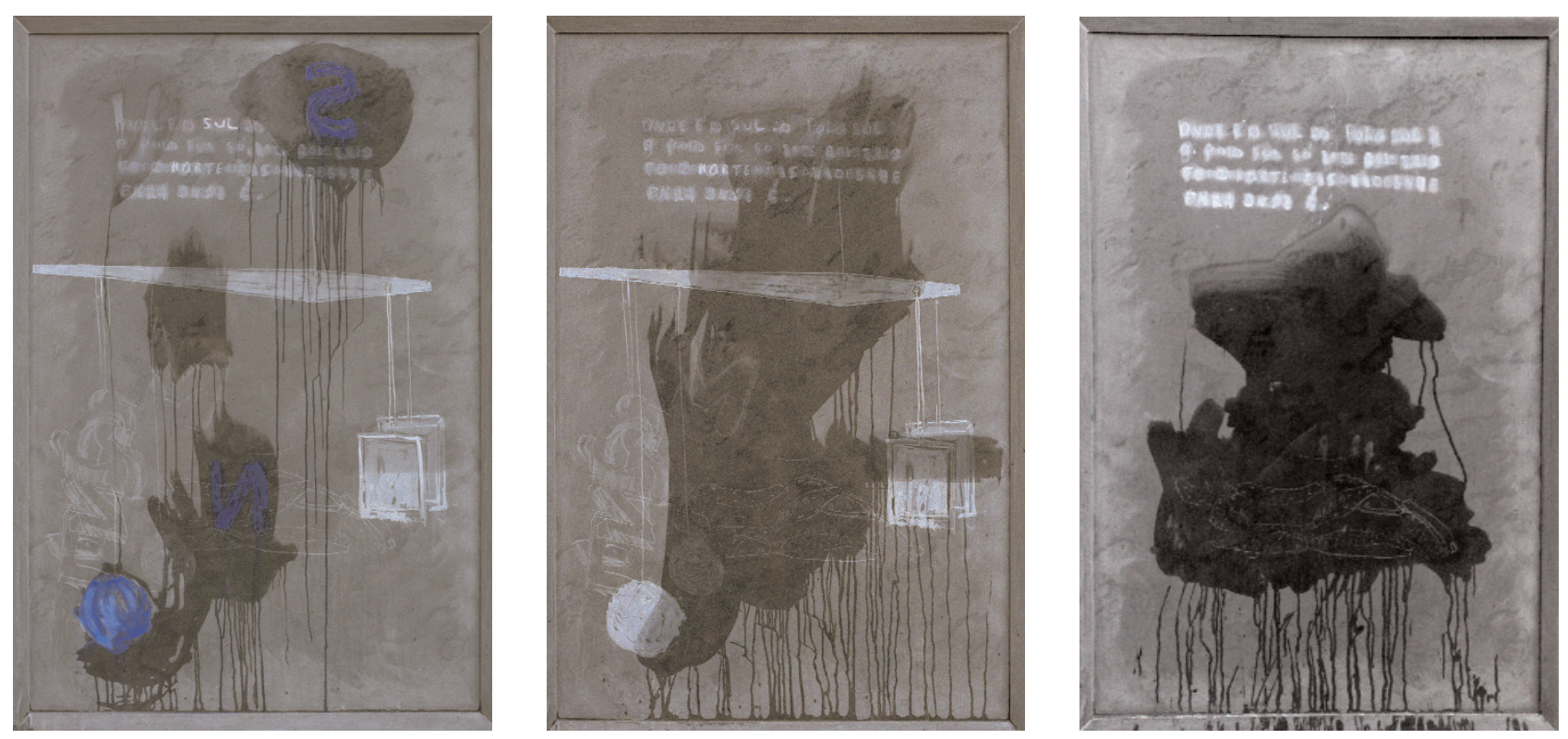

$\vartheta$
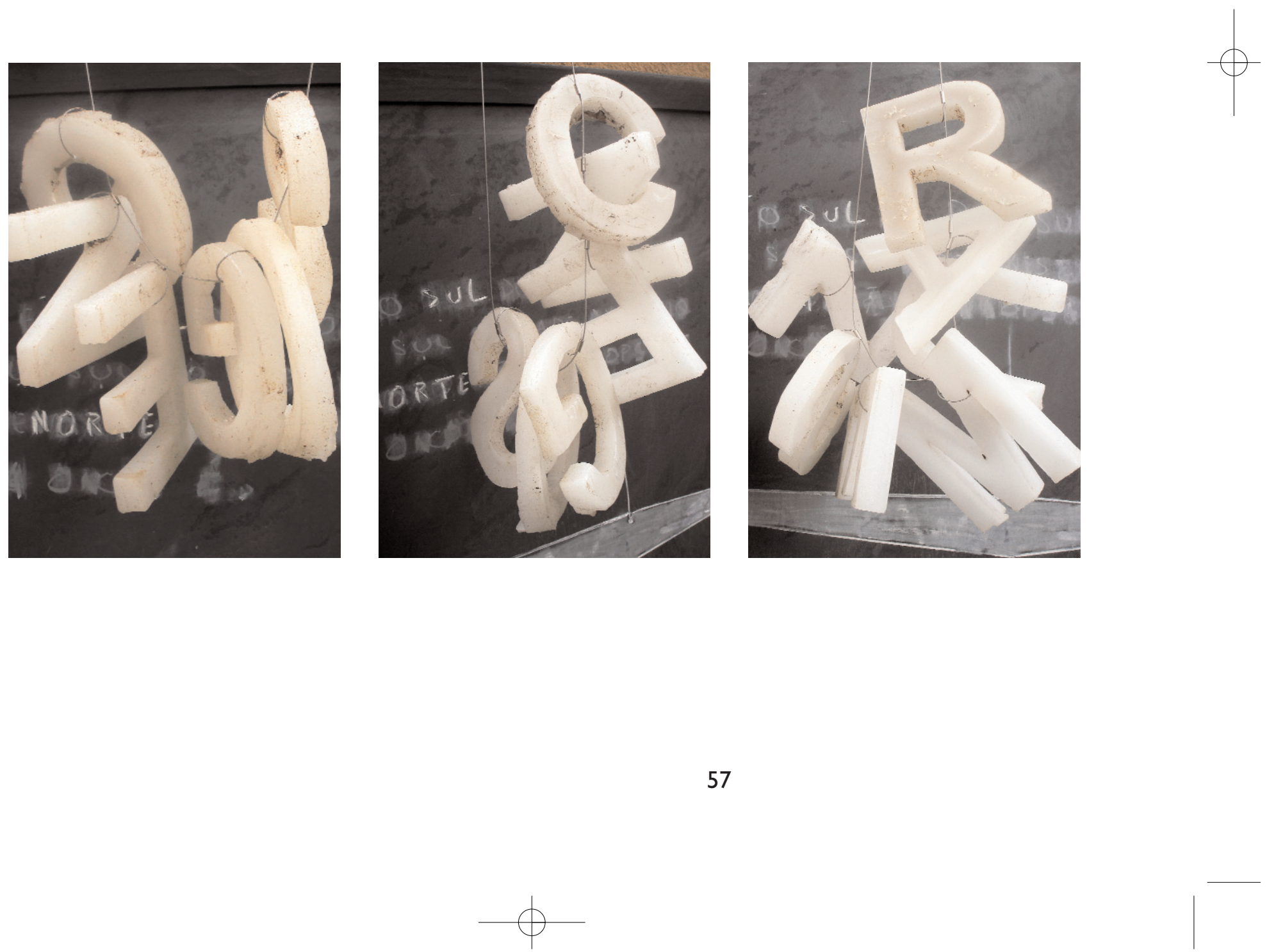


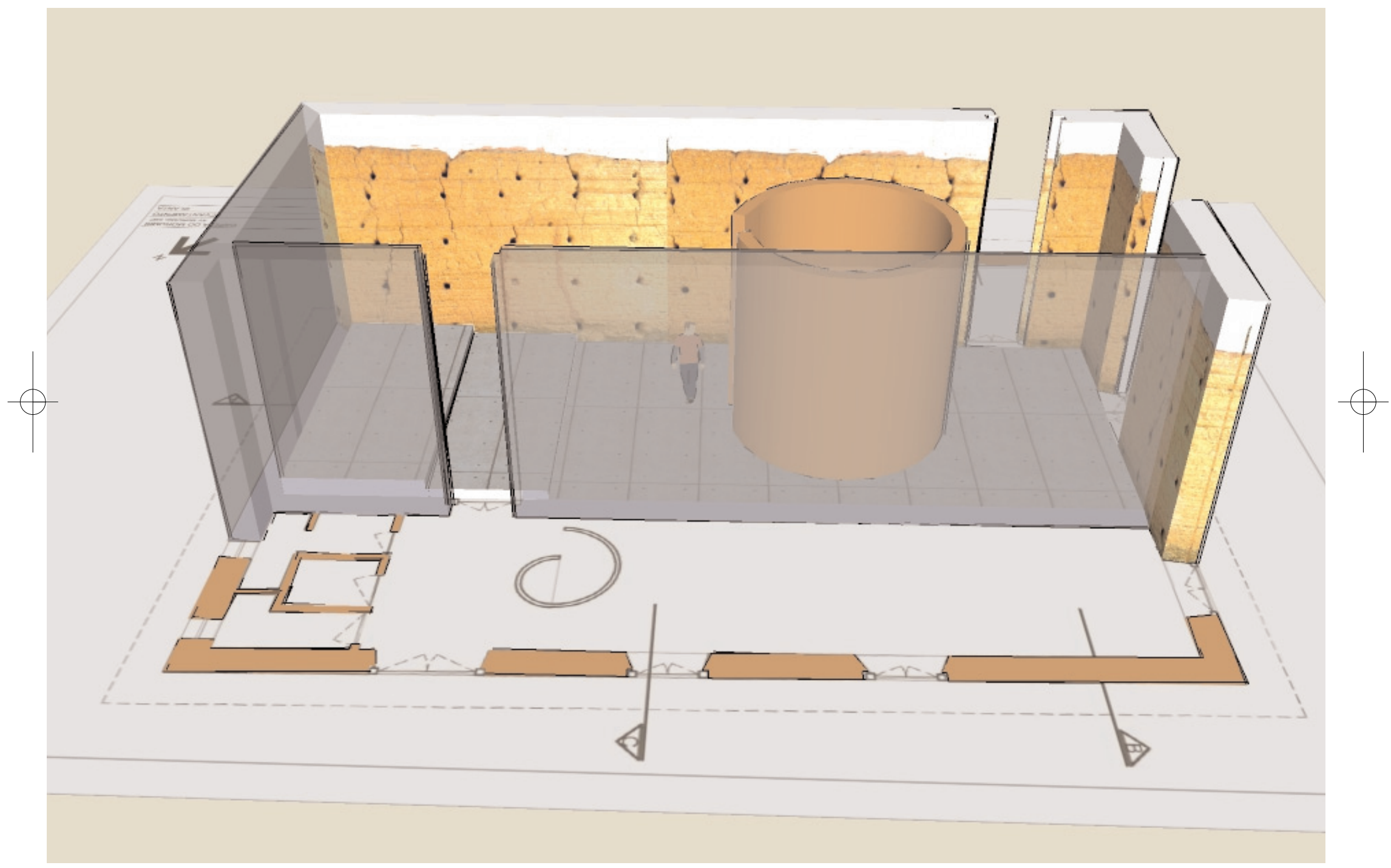

Tímpano, trabalho a ser realizado durante o mês de maio de 2009, Capela do Morumbi. 


\section{Tímpano}

Tímpano é o nome de um novo trabalho projetado para a área central da Capela do Morumbi, um dos espaços pertencentes ao Museu da Cidade em São Paulo. Constitui-se de uma peça circular construída em taipa de pilão, a mesma técnica utilizada na construção da capela. Um grande cilindro de $4 \mathrm{~m}$ de altura, $4 \mathrm{~m}$ de diâmetro, paredes de $25 \mathrm{~cm}$ de espessura, com um recorte vertical no arco voltado para o altar. Esta abertura dará acesso à parte interna da peça.

A palavra tímpano, em seu sentido original, diz respeito a peças semelhantes a sinos ou tambores, que percutidas por martelos produzem sons. Em arquitetura, define duas áreas triangulares ligadas ao frontão e aos arcos. Ligados à parte interna dos frontões e à parte externa restante dos arcos, em geral são decorados com relevos e frisos. Mas hoje, quando mencionamos a palavra tímpano, o primeiro sentido a que aludimos é o da anatomia. Refere-se à membrana fina e tensa que constitui o limite entre a orelha externa e a orelha média, funciona como um tambor na cavidade timpânica. Se nos três casos assume funções completamente diversas, penso que exista uma unidade entre os sentidos referidos por ela. A palavra está sempre ligada a uma idéia de limite entre espaço interno e externo, de vazio, de propagação e reflexão.

Os sinos fazem ecoar, projetam os sons para longe. $\mathrm{O}$ eco é produzido pela reflexão do som, que ao retornar a nós mesmos se mostra outro. $\mathrm{O}$ eco nos dá um sentido de profundidade espacial e temporal, o som que nos chega de volta já não é o mesmo, se mostra enfraquecido. Projeta-se e, ao encontrar um anteparo rígido, rebate e volta em nossa direção. Nesse momento ouvimos nossa própria voz uma segunda vez. A primeira no momento em que falamos, a segunda quando o eco a traz de volta. $\mathrm{O}$ eco é capaz de subitamente ocupar todo o espaço de um vale e transformar a distância em sensação física. Como se por um instante fosse possível tatear toda a paisagem.

$\mathrm{Na}$ arquitetura, o tímpano é uma espécie de conseqüência das soluções construtivas, do esforço para edificar e organizar o espaço. Existe como uma área de transição, um intervalo entre um elemento e outro da fachada: o limite entre a parede e o telhado, ou entre o arco e a viga. No frontão, esconde o madeiramento do telhado e a inclinação das águas; nos arcos, se refere ao semicírculo na parte interna e aos dois lados da parte externa. Nos dois casos, gera um espaço indefinido e vazio que deve ser de alguma forma preenchido. Curiosamente o que para a arquitetura é um espaço residual, para a arte torna-se um lugar ideal para ser ocupado. Se para o edifício é uma espécie de lacuna, uma área ambígua, ganha sentido com a escultura,

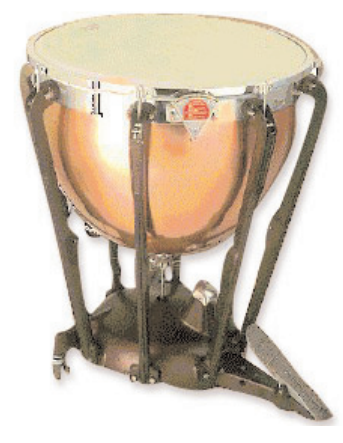

Tímpano: tambor.
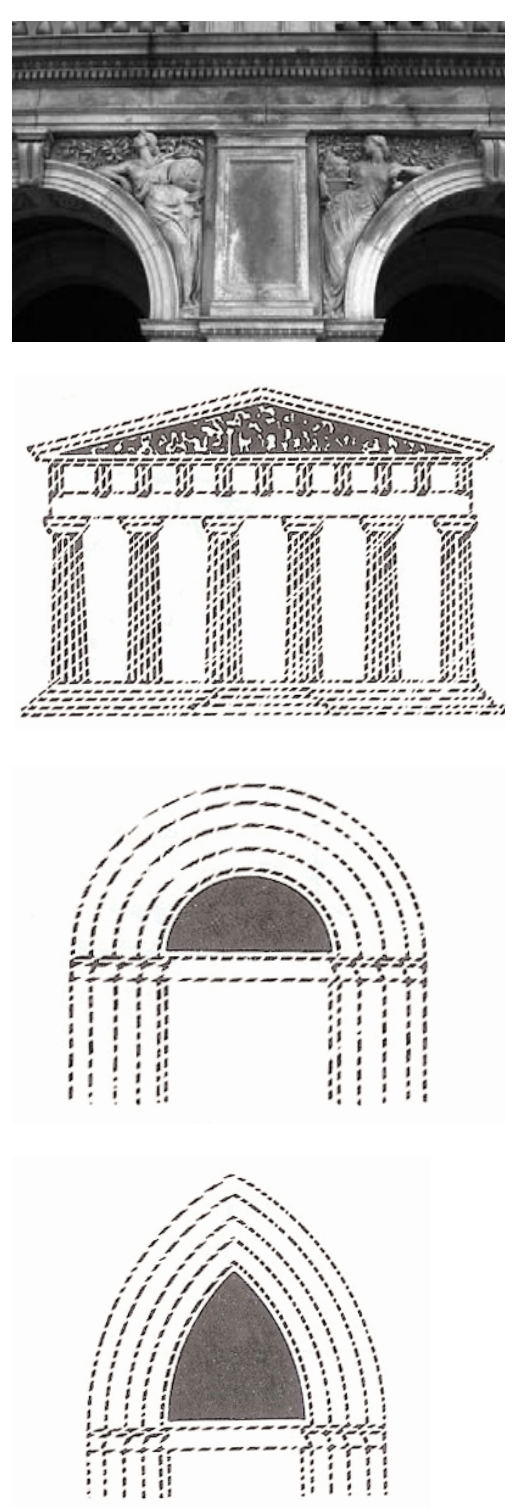

Exemplos de tímpano na arquitetura. 
${ }^{9}$ Contemplar: visão de futuro a partir da observação do vôo das andorinhas diante do frontão de um templo. Giannotti, Marco. Desvio para a Pintura, tese de doutorado, ECA-USP, 1998. com os relevos e os ornamentos. Mais uma vez revela-se, portanto, essa afinidade arcaica entre o fazer artístico e a falta de função. Curiosamente, é o frontão que vai dar origem a uma importante palavra para as artes: contemplar ${ }^{9}$. A cena representada no tímpano torna possível, para quem está do lado de fora, compreender um pouco da natureza do edifício. A imagem devidamente traduzida no frontão faz com que a lógica do espaço interno repercuta e seja transmitida para o espaço público.

Ao contrário, quando ligado à anatomia, o tímpano refere-se a um mecanismo de interiorização. Trata-se de uma membrana fina, suficientemente sensível para internalizar as vibrações do espaço externo. Esta película é uma espécie de sensor, capaz de registrar e absorver as mais delicadas ondas sonoras, possibilitando, através da audição, a assimilação das manifestações do mundo exterior.

O objeto que pretendo construir estabelece relações de semelhança e contraste em relação à capela. As de semelhança estão ligadas à terra como elemento comum, criando uma relação de espelhamento pela unidade da matéria. Este fato termina por dotar a escultura de um certo mimetismo em relação à igreja, como se houvesse uma continuidade entre esses elementos. As paredes de terra têm algo de epidérmico, mostram na sua porosidade a ação do tempo. Destacam a questão temporal que a matéria viva do edifício revela. Na capela, as paredes seculares irão ressaltar ainda mais a matéria recém-modelada da nova construção. Como uma cor nova e uma outra que já desbotou. A terra torna-se signo de memória, remetendo à história das gerações passadas e às suas experiências.

Por outro lado, a forma cúbica da pequena igreja contrasta fortemente com a linha curva da escultura. A arquitetura em confronto com o objeto enfatiza, através dos vãos entre as formas, a verticalidade presente na nave da capela. A própria terra, normalmente um dos signos da horizontalidade, neste caso é posta de pé. 


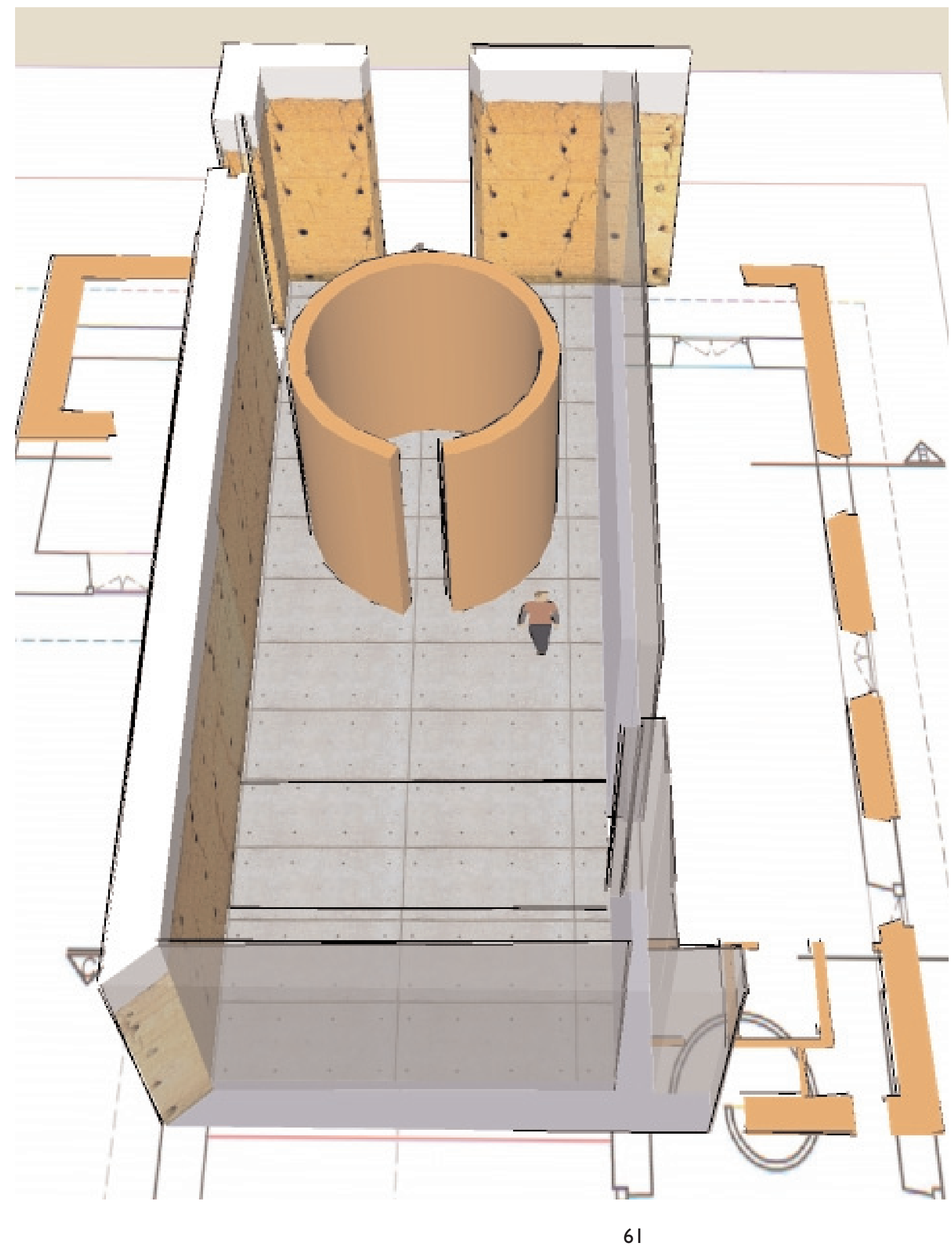




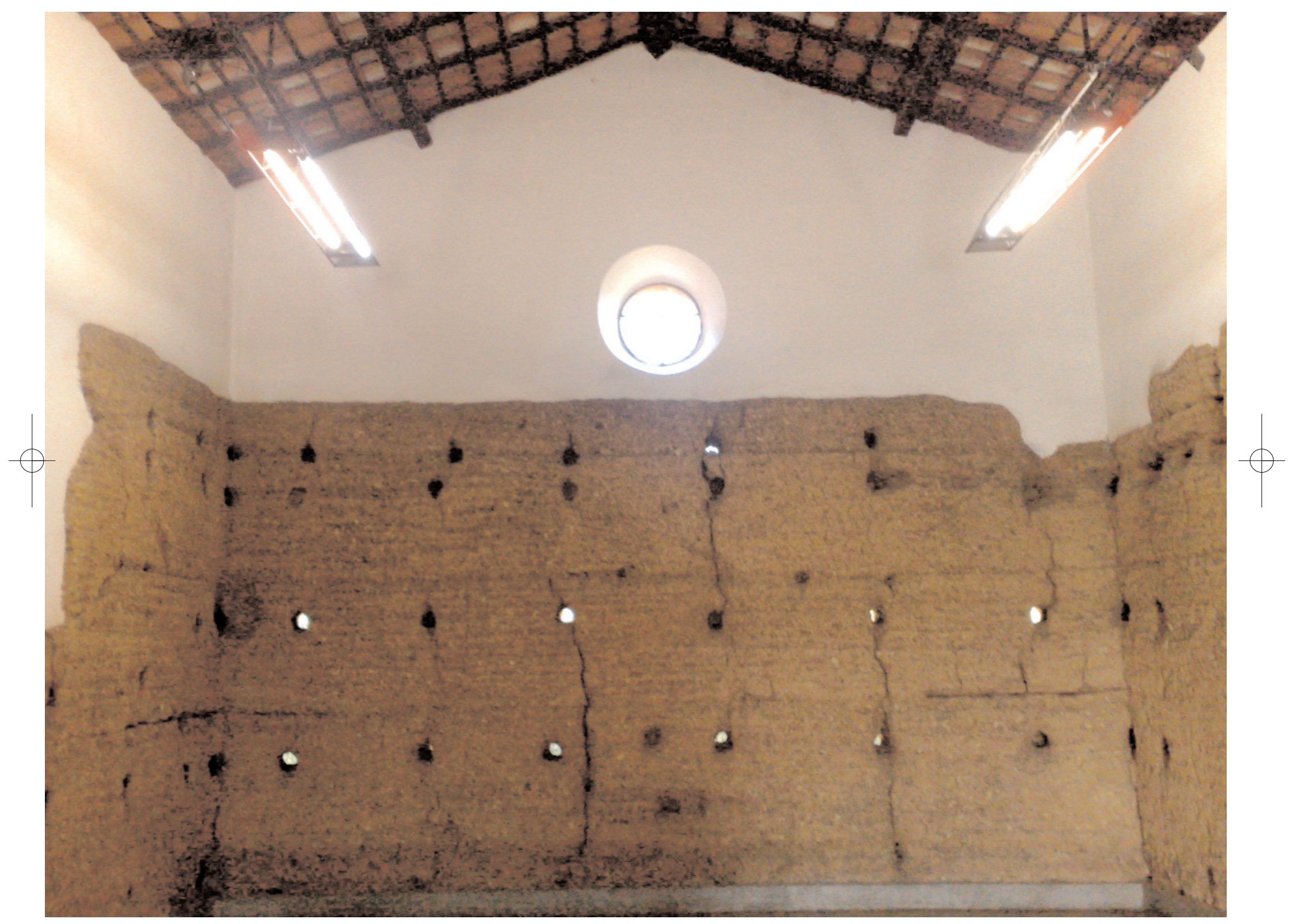

Capela do Morumbi, São Paulo. 


\section{Bibliografia}

Argan, Giulio Carlo. Michelangelo Architect. Phaidon Press, Electa Architeture, Londres, 2004.

Argan, Giulio Carlo. Imagem e persuasão. Companhia das Letras, São Paulo, 2004.

Beuys, Josef. Mein Dank an Lehmbruck. Schirmer/Mosel, München, 2006.

Cabanne, Pierre. Marcel Duchamp: Engenheiro do Tempo Perdido. Perspectiva, São Paulo, 1997 (Série Debates).

Cervantes, Miguel. O Engenhoso Fidalgo Don Quixote de la Mancha. Itatiaia, Belo Horizonte, 1997.

Clair, Jean; Linde, Ulf. Marcel Duchamp abécédaire. Musée National d'Art Moderne, Centre National d'Art et de Culture Georges Pompidou, Paris, 1977.

Dieter, Daniels. Duchamp und die anderen. DuMont Buchverlag, Köln, 1992.

Duchamp, Marcel. Manual of Instructions for "ETANT DONNÉS: 1 " LA CHUTE DÉAU $2^{\circ}$ LE GAZ D'ÉCLAIRAGE”. Philadelphia Museum of Art, Filadélfia, 1987.

Flusser,Vilém. Ficções Filosóficas. Edusp, São Paulo, 1998.

Foucault, Michel. As Palavras e as coisas. Martins Fontes, São Paulo, 1981.

Gayford, Martin; Writht, Karen (Eds.). The Grove Book of Art Writing. Grove Press, New York, 1998

Halpnern, Daniel. Writing on Artists. North Point Press, San Francisco, 1998.

Herzogenrath, Wulf. Mehr als Malerei. Vom Bauhaus zur VideoSkulptur. Schmid, Karlheinz; Gabriele Lindinger, Regensburg, 1994.

Jung, Carl Gustav. O Símbolo da transformação na Missa. Vozes, Petrópolis, 1979. 
Kounellis, Jannis. Der Wind - Texte und Zeichnungen. Kleine Edition Nautilus, Hamburg, 2006.

Max, Roberto Burle. Arte e Paisagem - conferencias escolhidas. Nobel, Rio de Janeiro, 1987.

Ortega y Gasset, José. Papeles sobre Velázquez y Goya. Revista de Occidente en Alíanza Editorial, Espanha, 1987.

Ortega y Gasset, José. Adão no Paraíso e outros ensaios de estética. São Paulo, Cortez, 2002.

Ortega y Gasset, José. Meditações do Quixote. Livro Ibero Americano, Lisboa, 1967.

Ortiz, Antonio Domínguez; Sánchez, Alfonso E. Pérez; Gállego, Julián. Velázquez. Ministerio da Cultura, Museo del Prado, Madri, 1990.

Philp, Annette. Photographie interpretiert Skulptur - Auguste Rodin, Constantin Brancusi, Alberto Giacometti. Gerstmeyer, Dr, Thomas, Berlin, 2000.

Pope-Hennessy, John. Italian High Renaissance \& Barroque sculpture, an introduction to Italian Sculpture. Vintage Books Edition, New York, 1985.

Salzstein, Sônia, org. Mira Schendel. Editora Marca D’Água, 1996.

Schwarz, Arturo. The Complete Works of Marcel Duchamp. Delano Greenidge Editions, New York, 2000.

Zweite, Armin. Joseph Beuys - Natur Materie Form. Künstsammlung Nordrheim-Westfalen, Düsseldorf, 1991. 
doutorado 4/27/09 10:01 PM Page 65 
